ESTIMATION OF THE RECHARGE AREA OF A PUMPED, STRATIFIED-

DRIFT AQUIFER IN CONNECTICUT BY SIMULATION MODELING

By David L. Mazzaferro

U.S. GEOLOGICAL SURVEY

Water-Resources Investigations Report 87-4124

Prepared in cooperation with the

MIDSTATE REGIONAL PLANNING AGENCY

MIDDLETOWN, CONNECTICUT

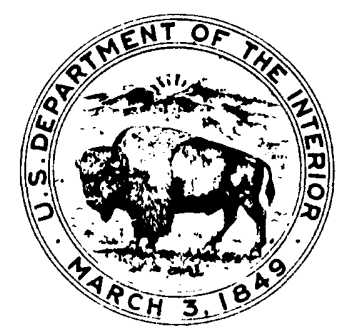

Hartford, Connecticut

1989 
DEPARTMENT OF THE INTERIOR

MANUEL LUJAN, JR., Secretary

U.S. GEOLOGICAL SURVEY

Dallas L. Peck, Director

For additional information write to:

Chief, Connecticut office U.S. Geological Survey, WRD Abraham A. Ribicoff Fed. B Idg. 450 Main Street - Room 525 Hartford, CT 06103
Copies of this report can be purchased from:

Books \& Open-File Reports U.S. Geological Survey Box 25425, Federal Center Denver, CO 80225 


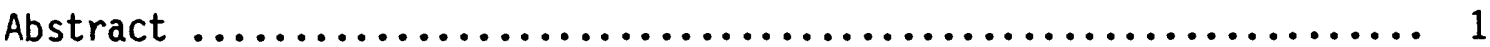

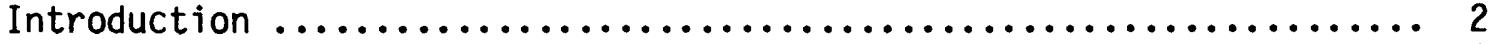

Purpose and scope $\ldots \ldots \ldots, \ldots, \ldots, \ldots, \ldots, \ldots, \ldots, \ldots, \ldots, \ldots, \ldots, \ldots, 2$

Methods of investigation $\ldots \ldots \ldots \ldots \ldots \ldots \ldots \ldots \ldots, \ldots \ldots, \ldots, 2$

Locations and descriptions of the aquifers $\ldots \ldots \ldots \ldots \ldots \ldots \ldots, 4$

Hypothetical aquifer $\ldots \ldots \ldots \ldots \ldots \ldots \ldots \ldots \ldots \ldots \ldots, 4$

Farmington aquifer $\ldots \ldots \ldots \ldots \ldots \ldots \ldots \ldots \ldots \ldots \ldots \ldots, 4$

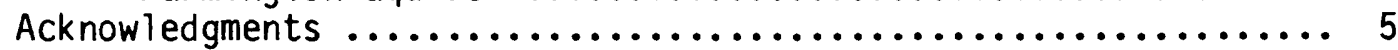

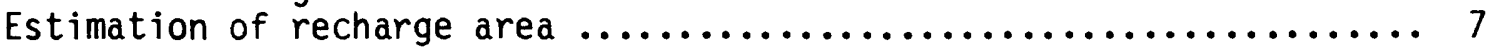

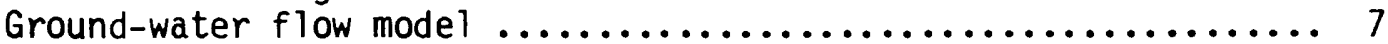

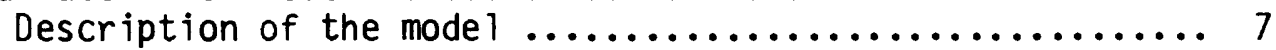

Elements common to the aquifer models ................. 9

Hypothetical aquifer and model $\ldots \ldots \ldots \ldots \ldots \ldots \ldots \ldots \ldots \ldots, 10$

Characteristics of the hypothetical aquifer ............. 10

Description of the hypothetical-aquifer model ............ 13

Simulations by the hypothetical-aquifer model $\ldots \ldots \ldots \ldots \ldots 16$

Results of hypothetical-aquifer model simulations ........ 19

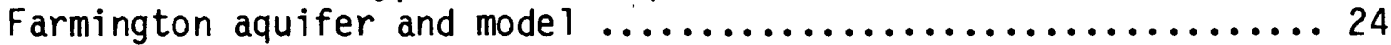

Characteristics of the Farmington aquifer ............. 24

Description of the Farmington aquifer model $\ldots \ldots \ldots \ldots \ldots .26$

Simulations by the Farmington aquifer model $\ldots \ldots \ldots \ldots \ldots . . .30$

Results of Farmington aquifer model simulations ......... 34

Data requirements and application of the technique to other areas ... 37

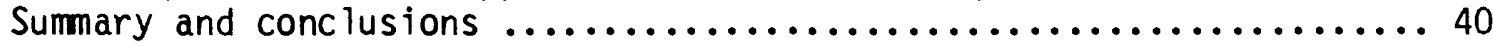

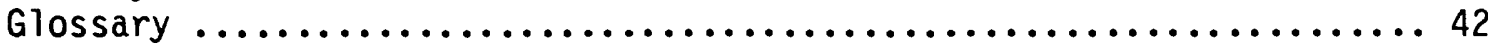

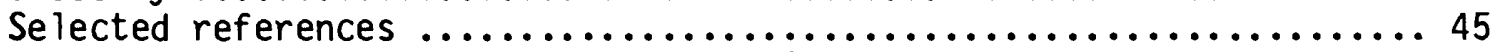

Appendix A: Listing of input for the initial hypothetical-aquifer model ......................47

B: Listing of input for the revised hypothetical-aquifer model $\ldots \ldots \ldots \ldots \ldots \ldots \ldots \ldots .61$

C: Listing of input for the

Farmington aquifer model $\ldots \ldots \ldots \ldots \ldots \ldots \ldots \ldots . \ldots 1$

\section{ILLUSTRATIONS}

A. Map showing simulated water-table altitude in the Farmington aquifer, average hydrologic conditions, no pumpage .... (In pocket)

B. Map showing simulated water-table altitude and area contributing flow in the Farmington aquifer, least-favorable hydrologic conditions, 2.8 million gallons per day

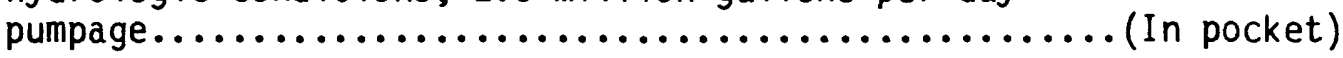

C. Map showing simulated water-table altitude and area contributing flow in the Farmington aquifer, average hydrologic conditions, 2.8 million gallons per day pumpage........ (In pocket) 
D. Map showing simulated water-table altitude and area contributing flow in the Farmington aquifer, most-favorable hydrologic conditions, 2.8 million gallons per day pumpage

Figure

1. Idealized spatial relations between a stratified-drift aquifer, model area, perennial stream, and adjacent contributing area ............................... 5

2. Maps showing location and extent of the Farmington aquifer ....................................... 6

3. Diagrams of the hypothetical-aquifer area showing the initial and revised model grids ..................... 12

4. Map showing water-table altitudes predicted by the hypothetical-aquifer model under average hydrologic conditions, steady-state conditions, and no pumpage

5. Maps showing water-table altitudes and areas contributing flow to a pumping center predicted by the hypotheticalaquifer model under average, least-favorable, and mostfavorable hydrologic conditions, assuming steady-state conditions and a withdrawal rate of 1.2 million gallons

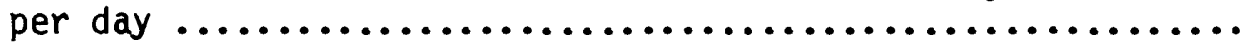

6. Map showing boundaries of the Farmington aquifer

model and dimensions of the cells in the model grid

7. Diagram of an idealized aquifer model area showing how flow from an adjacent area is apportioned over 10 boundary nodes

8. Map showing water-table altitudes in the most-favorable part of the Farmington aquifer, November 30 to December 1, 1976, under wetter-than-average conditions ........................ 31

9. Map showing simulated water-table altitudes in part of the Farmington aquifer as determined by model simulation ........

\section{TABLES}

Table

1. Sources and discharges of water determined by initial hypothetical-aquifer model under steady-state conditions .... 14

2. Sources and discharges of water determined by revised hypothetical-aquifer model under steady-state conditions .... 15 
3. Hydrologic elements, requirements, and mode1-generated values used to evaluate calibration simulations of initial and revised hypothetical-aquifer models ...................... 17

4. Recharge rates and hydraulic conductivity values chosen to represent least-favorable, average, and most-favorable conditions acting upon the hypothetical aquifer ........... 19

5. Summary of selected input parameters, drawdowns, and sizes of contributing recharge areas for 21 simulations of the hypothetical-aquifer model under steady-state and transient conditions ............................ 20

6. Recharge rates and hydraulic conductivity factors selected to represent least-favorable, average, and most-favorable conditions affecting the Farmington aquifer .............. 30

7. Sources and discharges of water determined by the Farmington aquifer model under steady-state conditions ............. 32

8. Pumping rates for three hypothetical wells tapping the Farmington River aquifer used in simulations of the aquifer mode 1 that represent least-favorable, average, and most-favorable hydrologic conditions ...................... 33

9. Summary of data from three steady-state simulations of the

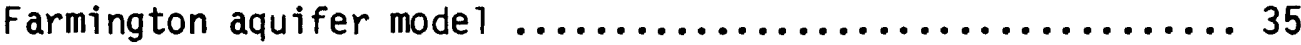

10. Sources and discharges of water determined by the Farmington aquifer model under pumping conditions $\ldots \ldots \ldots \ldots \ldots \ldots \ldots . \ldots . \ldots$ 
For the benefit of readers who prefer metric (International System) units rather than the inch-pound units in this report, the following conversion factors may be used:

Multiply inchpound unit by

To obtain metric unit

\begin{tabular}{|c|c|c|}
\hline \multicolumn{3}{|c|}{ Length } \\
\hline inch (in.) & 25.4 & millimeter (mm) \\
\hline foot $(f t)$ & 0.3048 & meter (m) \\
\hline mile (mi) & 1.609 & kilometer $(\mathrm{km})$ \\
\hline \multicolumn{3}{|c|}{ Area } \\
\hline square mile $\left(m i^{2}\right)$ & 2.590 & square kilometer $\left(\mathrm{km}^{2}\right)$ \\
\hline \multicolumn{3}{|c|}{ Flow } \\
\hline $\begin{array}{l}\text { cubic foot per second } \\
\left(\mathrm{ft}^{3} / \mathrm{s}\right)\end{array}$ & 0.02832 & $\begin{array}{l}\text { cubic meter per second } \\
\left(\mathrm{m}^{3} / \mathrm{s}\right)\end{array}$ \\
\hline $\begin{array}{l}\text { gallon per minute } \\
\text { (gal/min) }\end{array}$ & 0.06309 & $\begin{array}{l}\text { liter per second } \\
(1 / s)\end{array}$ \\
\hline $\begin{array}{l}\text { million gallons per day } \\
(M g a l / d)\end{array}$ & 3785.67 & $\begin{array}{l}\text { cubic meters per day } \\
\left(m^{3} / d\right)\end{array}$ \\
\hline \multicolumn{3}{|c|}{ Hydraulic Units } \\
\hline $\begin{array}{l}\text { hydraulic conductivity, } \\
\text { foot per day (ft/d) }\end{array}$ & 0.3048 & $\begin{array}{l}\text { hydraulic conductivity, } \\
\text { meter per day }(\mathrm{m} / \mathrm{d})\end{array}$ \\
\hline $\begin{array}{l}\text { hydraulic gradient, } \\
\text { foot per mile (ft/mi) }\end{array}$ & 0.1894 & $\begin{array}{l}\text { hydraulic gradient, } \\
\text { meter per kilometer } \\
(\mathrm{m} / \mathrm{km})\end{array}$ \\
\hline \multicolumn{3}{|c|}{$\begin{array}{l}\text { Sea level: In this report "sea level" refers to the National Geodetic } \\
\text { Vertical Datum of } 1929 \text { (NGVD of 1929)-- geodetic datum derived from a } \\
\text { general adjustment of the first-order level nets of both the United } \\
\text { States and Canada, formerly called "Mean Sea Level of } 1929 \text { ". }\end{array}$} \\
\hline
\end{tabular}




\title{
ESTIMATION OF THE RECHARGE AREA OF A PUMPED, STRATIFIED-DRIFT AQUIFER IN CONNECTICUT BY SIMULATION MODELING
}

\author{
by
}

David L. Mazzaferro

\section{ABSTRACT}

The protection of ground-water sources in Connecticut against possible contamination requires information about the extent of the recharge areas that contribute flow to specific pumping centers. In those parts of the State underlain by extensive, stratified-drift deposits, this information is especially important because of political and economic considerations. This report describes a technique for using digital, ground-water flow models to determine the sizes and shapes of these contributing recharge areas.

Two finite-difference, ground-water flow models constructed to simulate flow in a hypothetical, stratified-drift aquifer show that it is feasible to use this type of model to investigate how recharge areas change in response to specific stresses. A third finite-difference model was constructed to simulate flow in the extensive, stratified-drift aquifer in Farmington, Connecticut, and to show how the size and shape of the area contributing recharge to a pumping center changes as recharge rates and hydraulic conductivities are varied to represent average, least-favorable, and mostfavorable conditions.

Twenty-one simulations of the hypothetical aquifer are made using recharge rates of $0,15,25$, and 35 inches per year, and aquifer hydraulic conductivities of 25,75 , and 225 feet per day. Steady-state and 180-day transient conditions are simulated. A withdrawal rate of 1.2 million gallons per day, under steady-state conditions, with 15 inches per year of recharge and a hydraulic conductivity of 25 feet per day, resulted in the largest contributing recharge area for the hypothetical aquifer ( 0.75 square miles). The same withdrawal rate, a 180-day pumping period, 35 inches per year of recharge, and a hydraulic conductivity of 225 feet per day, resulted in a much smaller contributing area ( 0.15 square miles). Contributing recharge areas for simulations with 180-day pumping periods averaged 8 percent smaller than simulations run under steady-state conditions. Three simulations of the Farmington aquifer model that incorporate a withdrawal rate of about 2.8 million gallons per day were then made and evaluated. Under average conditions ( 30 inches per year recharge and field-determined values for hydraulic conductivity), the size of the area contributing flow to the pumping center was 1.37 square miles. As recharge rates and hydraulic conductivity values were varied from least favorable to most favorable, the size of the area contributing flow decreased from 1.94 to 0.89 square miles. 
The results of these simulations indicate that both the size and shape of the recharge area that contributes flow to a pumping center can be estimated by means of a ground-water flow model. The simulations also indicate that the accurate determination of hydrologic parameters and aquifer characteristics is an important part of the process. If natural recharge rates and actual hydraulic conductivities differ significantly from those used in the model, or if improper boundary conditions are assumed, erroneous estimates of the configuration of the contributing area may result.

\section{INTRODUCTION}

The protection of major sources of ground water from possible contamination and the long-term assurance of acceptable water quality requires information on the size and shape of the recharge areas that contribute flow to specific pumping centers. Ground-water-quality management plans for small stream-aquifer systems in Connecticut proposed by the Connecticut Areawide Waste Treatment Management Planning Board (1979) cannot be applied to those parts of the State that are underlain by extensive stratified-drift aquifers because of political and economic considerations. These larger aquifers, which may underlie a major part of one or more towns, are composed of materials that range in size from fine sand to boulder gravel. As a consequence of the large areal extent of these aquifers, their geologic variability, and present land use, information is needed about the size and shape of the smaller area within the larger stratified-drift deposit that would contribute flow to a specific pumping center under a typical pattern of ground-water development.

\section{Purpose and Scope}

This report describes the procedure and evaluates the feasibility of using a two-dimensional, digital, ground-water flow model to determine the size and shape of the area contributing flow to a pumping center in a large stratified-drift aquifer. It also discusses how the size and shape of this area changes in response to variations in natural recharge rates and variations in average horizontal hydraulic conductivity of the aquifer. Other factors such as leakage from streams and variations in specific yield al so may affect the configuration of the area contributing flow to a center of pumping, but are beyond the scope of this study.

\section{Methods of Investigation}

In an idealized aquifer with no boundaries, the size of the area contributing flow to a well, under steady-state conditions, can be estimated by considering the simple relation that exists between the contributing area, the recharge rate and the pumping rate:

$$
\text { Area = Pumping rate/Recharge rate }
$$


Assuming a pumping rate of $1.2 \mathrm{Mgal} / \mathrm{d}$ (million gallons per day), a recharge rate of $25 \mathrm{in./yr}$ (inches per year), and the above relation, the size of the area contributing water to a well is estimated to be $1.01 \mathrm{mi}^{2}$ (square miles). However, practical considerations such as the existence of aquifer boundaries, the need to evaluate finite pumping periods, and knowledge that variations in aquifer hydraulic conductivity affect the shape of the contributing area are factors that make this type of analysis inadequate.

In order to evaluate the feasibility of using a ground-water flow model to more accurately define the size and shape of a contributing recharge area in a real aquifer, a two-dimensional, finite-difference, ground-water flow model (Trescott and others, 1976) of a hypothetical aquifer was first constructed. This hypothetical-aquifer model was then used to investigate how the configuration of the contributing recharge area changed in response to variations in recharge rates and variations in aquifer hydraulic conductivity. The model also was used to investigate changes in the configuration of the contributing recharge area under both steady-state and transient (finite pumping period) conditions. The hypothetical aquifer was initially assigned hydrologic characteristics typical of the extensive, stratified-drift aquifers common to southern New England. Selected model input data were adjusted during a series of steady-state simulations until water-table altitudes, ground-water outflow, and the mass balance, as determined by the model, were considered reasonable. The model was then operated for a series of 21 simulations, during which $1.2 \mathrm{Mgal} / \mathrm{d}$ were withdrawn from a pumping center, and recharge rate, aquifer hydraulic conductivity, and period of pumping were varied. After the simulations were completed, water-table maps were prepared and used to define the configuration of the area contributing recharge to the pumping center under different conditions. The technique used to define the contributing area consisted of the following steps:

(1) A map showing water-table altitude under pumping conditions was constructed using head-distribution data obtained from the model. The map has closely spaced water-table contours (1-foot interval) in the immediate vicinity of the pumping center and more widely spaced contours (2- to 5-foot interval) in areas farther away.

(2) The shape of the water-table contours, especially in the vicinity of the pumping center, was examined and the directions of the horizontal components of ground-water flow were determined.

(3) A ground-water divide separating the region that contributed flow to the pumping center from the rest of the aquifer was plotted.

In this manner, the size and shape of the area contributing flow to the pumping center was estimated for each simulation.

Recharge rates were varied from 0 to $35 \mathrm{in./yr}$, average aquifer hydraulic conductivity was varied from 25 to $225 \mathrm{ft} / \mathrm{d}$ (feet per day), and either steady-state conditions or 180-day time periods were specified. The resulting water-table maps and drawdowns at the pumping center were then used to evaluate how, for each simulation, changes in recharge and hydraulic conductivity affected the size and shape of the contributing recharge area. 
After an analysis of the data provided by the model of the hypothetical aquifer, a model representing a stratified-drift aquifer in Farmington, Connecticut was constructed. Information obtained from simulations of the hypothetical-aquifer model guided construction and operation of the Farmington aquifer model principally with respect to grid dimensions and selection of ranges of hydrologic parameters.

A pumping center with three hypothetical wells was established in the vicinity of River Glen, an area previously identified as favorable for ground-water development in the Farmington aquifer (Mazzaferro, 1980). Simulations representing average, least-favorable, and most-favorable combinations of recharge rates and hydraulic conductivities were then made and used to determine the size and shape of the contributing recharge area under these three conditions.

Listings of the input data used in the construction of the hypothetical-aquifer and Farmington aquifer models described in this report are shown in Appendixes A-C. These data were used for steady-state, non-pumping simulations of the three aquifers, under average hydrologic conditions. They represent the numerical configurations of the aquifer models under discussion, after calibration.

\section{Locations and Descriptions of the Aquifers}

Hypothetical Aquifer

This aquifer does not represent a specific location or set of hydrologic characteristics. It represents a composite group of hydrologic characteristics generally typical of large stratified-drift aquifers in southern New England. The hypothetical aquifer is composed of sand and gravel, has an average hydraulic conductivity of $75 \mathrm{ft} / \mathrm{d}$, and is about 100 to 200 feet thick. The aquifer is unconfined and has a lower bedrock boundary that is impermeable. A large, perennial stream crosses, and is hydraulically connected to the aquifer. Adjacent areas may contribute water to the hypothetical aquifer or receive water from it. (See figure 1.)

\section{Farmington Aquifer}

The Farmington aquifer is located mostly within the Town of Farmington and is part of a large stratified-drift body that underlies much of the lower Farmington River valley in central Connecticut. This extensive deposit of gravel, sand, silt, and clay extends north and northwest along the Farmington River valley and continues south to the Quinnipiac River valley. In the Town of Farmington, the aquifer is traversed by the Farmington River and one of its major tributaries--the Pequabuck River. (See figure 2.)

Stratified drift in Farmington is generally coarse grained (sand and gravel) at the surface and fine grained (clay and silt) at depth. Hydraulic conductivity of the coarse-grained material ranges from about 20 to 150 $\mathrm{ft} / \mathrm{d}$; its saturated thickness ranges from a few feet to 100 feet or more in some areas. 


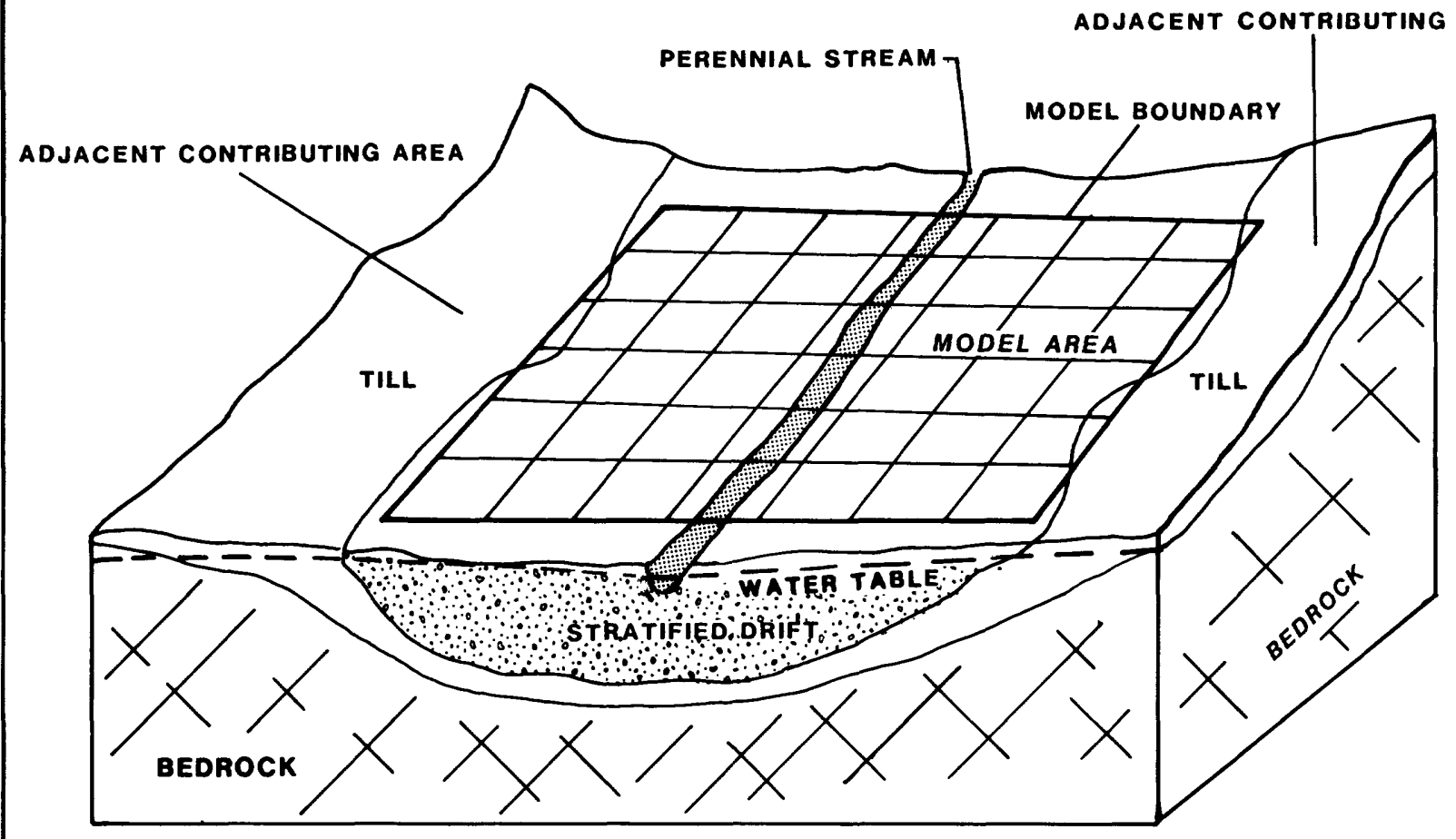

Figure 1.--Idealized spatial relations between a stratified-drift aquifer, model area, perennial stream, and adjacent contributing area

Several hydrologic studies that include all or part of the Farmington aquifer area have been published in the past 20 years (Randa 11, 1964a; Melvin, 1976; Mazzaferro, 1980; Handman and others, 1986). Basic data for the area have been published in Randal1 (1964b), Hopkins and Handman (1975), and U.S. Geological Survey (1966-83). Maps of the surficial geology of the area have been prepared by Colton (1970), Schnabel (1962), and Simpson $(1959,1961)$. These publications provided data for the construction and calibration of the aquifer model.

\section{Acknowledgments}

This investigation was conducted by the U.S. Geological Survey in cooperation with the Midstate Regional Planning Agency as part of the Connecticut 208 program under Public Law 92-500. Data on which this report is based were collected, compiled, and analyzed by the U.S. Geological Survey. Thanks are given to J. W. Bingham, U. S. Geological Survey, and D. K. McKeegan and S. E. Wing, formerly of the U.S. Geological Survey, who assisted in the construction of the digital models. Special thanks are also given to L. J. Torak, U.S. Geological Survey, who developed a critically needed option to the two-dimensional, finite-difference model program that was used in this investigation. 


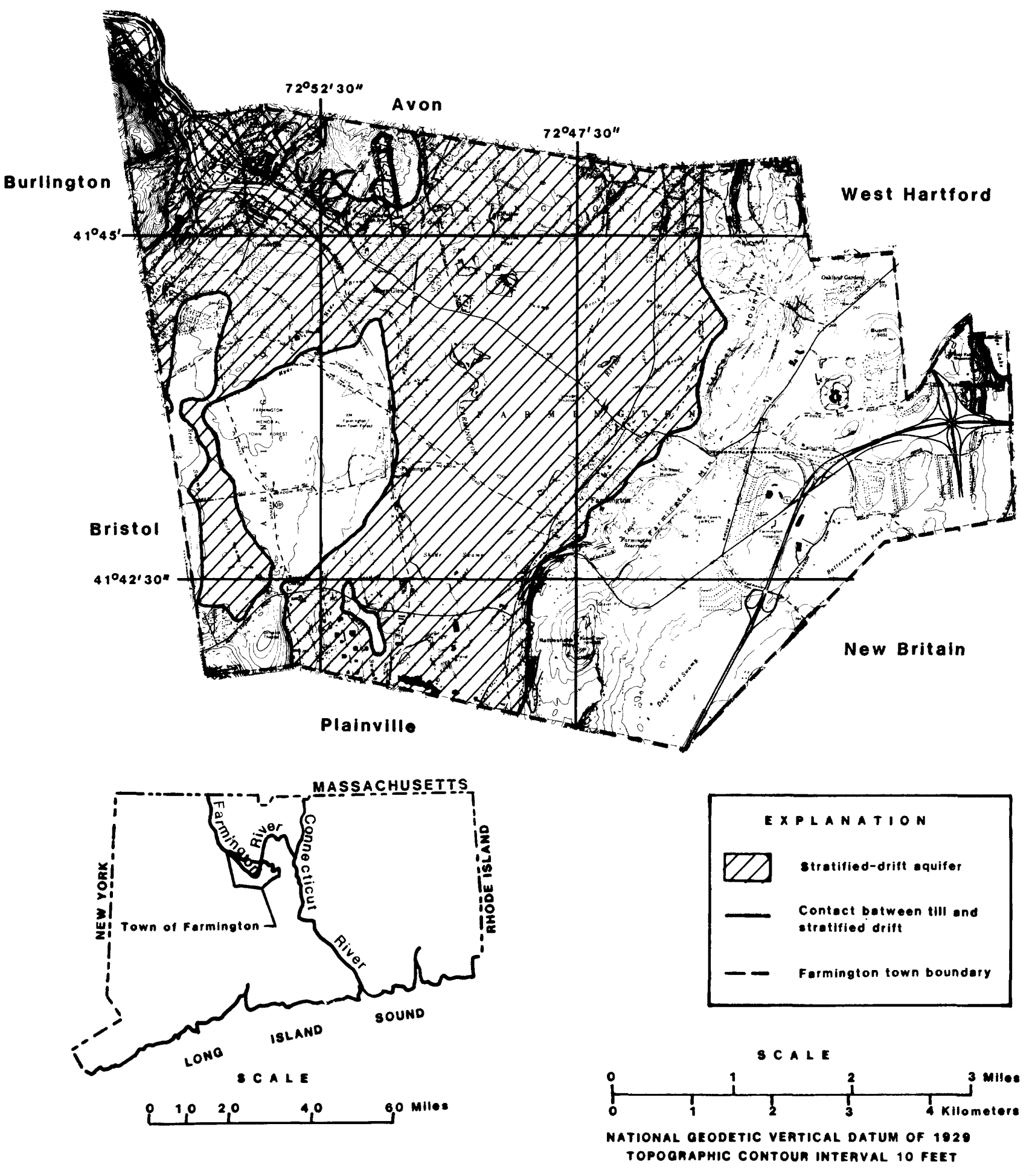

Figure 2.--Location and extent of the Farmington aquifer 


\section{ESTIMATION OF RECHARGE AREA}

\section{Ground-Water Flow Model}

Description of the Model

The hypothetical aquifer and the Farmington aquifer were evaluated with a finite-difference model developed by Pinder and Bredehoeft (1968) and refined by Trescott and others (1976). The model simulates horizontal ground-water flow and can be applied to unconf ined (water-table) aquifers that have irregular boundaries and areal variations in the ir hydrologic characteristics. In general, the model operates on specif ic input data (initial head distribution, recharge and discharge components, and aquifer characteristics) and calculates the total sources, total discharges, head distribution and head changes that occur after some time interval. Sources of water include recharge from precipitation, inflow across boundaries, and leakage from streams (induced recharge). Discharges include ground-water evapotranspiration, outflow across boundaries, leakage to streams (groundwater runoff) and pumpage from wells. Quantities of water that are added to, or removed from the aquifer during transient simulations are treated as increases or decreases in storage.

The equation that describes ground-water flow in an unconfined aquifer can be written in two-dimensional, partial-differential form (Bredehoeft and Pinder, 1970) as:

where:

$$
\frac{\partial}{\partial x}\left(K_{x x} b \frac{\partial h}{\partial x}+\frac{\partial}{\partial y}\left(K_{y y} b \frac{\partial h}{\partial y}\right)=S_{y} \frac{\partial h}{\partial t}+W(x, y, t)\right.
$$

\footnotetext{
$K_{x x}, K_{y y}$ are the principal components of hydraulic conductivity operating in the $x$ and $y$ directions, respectively $\left(\mathrm{Lt}^{-1}\right)$;

$h$ is static head (L);

Sy is the specific yield of the aquifer (dimensionless);

$b$ is the saturated thickness of the aquifer (L);

$x, y$ are rectangular coordinates assumed to be co-linear with the major and minor flow axes (L);

$t$ is time $(t)$;

$W(x, y, t)$ is the volumetric flux of recharge or withdrawa 1 per unit surface area of the aquifer $\left(\mathrm{Lt}^{-1}\right)$.
} 
For all but the simplest problems, the partial-differential form of the flow equation as shown above, cannot be solved directly. A solution can be obtained by replacing the continuous derivatives of the partial-differential form by finite-difference approximations and solving algebraically. Details of this technique, together with documentation of the FORTRAN program that facilitates the solution are found in Trescott and others (1976). The program has the option of three different numerical solutions. The models in this report use the Strongly Implicit Procedure (SIP); detailed discussion of this procedure is found in Trescott and others (1976) and Remson and others (1971).

The use of a mathematical model to approximate a stream-aquifer system requires the adoption of a series of assumptions that enable the model to simulate the response of the natural system. The principal assumptions made for this study were:

(1) Flow in the aquifer is essentially horizontal.

(2) Recharge from precipitation is uniformly distributed over the aquifer and is constant for each simulation.

(3) Ground-water evapotranspiration, a model option used during simulations of the initial hypothetical aquifer and the Farmington aquifer, decreases linearly with depth of the water table and ceases completely at a specified distance below land surface.

(4) The aquifer is divided into a number of rectangular sections in which specific hydrologic characteristics are represented by average values.

(5) Ground water discharged by pumping wells is exported from the system.

(6) The stream stage remains constant for each simulation.

(7) Constant-flux boundaries are represented by a series of recharging and discharging wells.

(8) Drawdowns at pumping wells are not corrected for partial penetration or well-construction characteristics. This means the computed drawdown is the average for the rectangular section or block; drawdown at an actual well within the block would be considerably greater.

The assumptions listed above represent, to varying degrees, departures from conditions that exist in the natural system. The discrepancies however, are not considered great enough to produce significant errors in the simulation process. 


\section{Elements Common to the Aquifer Models}

The hypothetical aquifer has hydrologic characteristics similar to those of the large, stratified-drift aquifers in southern New England, of which the Farmington aquifer is typical. Information obtained from simulations of the hypothetical-aquifer model could therefore be used to evaluate the likely response of the Farmington aquifer model to specific stress conditions. In this regard, the hypothetical and Farmington aquifers and their models have a number of common elements:

(1) Water-table (unconfined) conditions prevail.

(2) A major stream is adjacent and hydraulically connected to the aquifer. Water can move from the aquifer to the stream or from the stream to the aquifer, depending on differences in hydraulic head.

(3) Areas of till and bedrock, and stratified drift that are adjacent to the modeled area are assumed to be hydraulically connected to it and are represented by constant-flux boundaries. For till and bedrock areas, the rate at which water enters or leaves the modeled area is a function of the recharge rate and areal extent of the adjacent area. For stratified-drift areas, the rate at which water enters or leaves the modeled area is a function of the average hydraulic gradient, average hydraulic conductivity, and cross-sectional area along the boundary. In addition, flows from adjacent areas are assumed to vary in direct proportion to changes in the model's recharge rate. For example, if recharge to the modeled area is reduced by 40 percent, flows from adjacent areas are also reduced 40 percent. In the model, recharging or discharging wells, located at appropriate nodes, are used to simulate these boundary conditions.

(4) Pumping centers used to evaluate the response of the aquifer to stress conditions are generally located in the center of the valley, near the stream. This was done because maximum saturated thicknesses (and, as a consequence, greatest potentially available drawdowns) are often found in the center of the larger stratifieddrift valleys and proximity to major streams increases the potential for induced recharge. Both factors tend to maximize the amount of water that can be obtained from an individual well.

(5) Variations to model input parameters are limited to changes in recharge (to simulate naturally occurring variations), and average aquifer hydraulic conductivity (to simulate variations caused by inexact parameter definition). 
Hypothetical Aquifer and Model

Characteristics of the Hypothetical Aquifer

In addition to the common characteristics described in the preceding section, the hypothetical aquifer was assigned the specific hydrologic coefficients discussed below. These values were derived from data contained in previously published reports that investigated extensive stratified-drift aquifers in Connecticut (Randal1, 1964a; Melvin, 1976; Mazzaferro and others, 1979; Mazzaferro, 1980; Ryder and others, 1981; Handman and others, 1986) or from reports that featured digital ground-water models (Haeni, 1978; Mazzaferro, 1986). As noted in the section of this report titled "Description of the Hypothetical-Aquifer Model", two models of the hypothetical aquifer--an initial model and a revised version--were eventually constructed. The revised model was essentially a smaller part of the initial model that used a finer grid spacing, different flows from adjacent areas, and eliminated the GWET (ground-water evapotranspiration) option. The principal hydrologic characteristics of the hypothetical aquifer and the differences between the two models are discussed below.

(1) Recharge from precipitation: During average conditions, recharge from precipitation is assumed to average $25 \mathrm{in./ \textrm {yr }}$ and is distributed uniformly over the model area. During least-favorable conditions the recharge rate is reduced to $15 \mathrm{in.} / \mathrm{yr}$ and during most-favorable conditions it is increased to $35 \mathrm{in.} / \mathrm{yr}$.

(2) Ground-water evapotranspiration: In Connecticut, under average hydrologic conditions, basinwide GWET rates are estimated to range between 4 and $7 \mathrm{in./yr}$. The calibrated version of the initial model of the hypothetical aquifer used a maximum GWET rate of 25 in./yr; this rate resulted in an effective GWET rate of 2.3 in./yr. Although this value falls below the GWET-rate range expected for Connecticut, it is thought to be reasonable since it reflects the fact that wetlands were not included in the initial model's construction. In the revised version of the model, the GWET option is not used in order to simplify the model's operation and evaluation. This means that the recharge rates used for simulations of the revised model that are discussed in more detail later in this report represent effective recharge and are not adjusted to account for water removed from the aquifer by the GWET process.

(3) Effective recharge: Water supplied to the aquifer by recharge from precipitation minus water lost from the aquifer by GWET. For the calibrated version of the initial model of the hypothetical aquifer the effective recharge rate was $22.7 \mathrm{in./yr}(25 \mathrm{in./ \textrm {yr }}$ minus $2.3 \mathrm{in.} / \mathrm{yr}$ ). For the revised model, effective recharge and recharge from precipitation rates are the same because the GWET option is not used. 
(4) Hydraulic conductivity: Assumed to average $75 \mathrm{ft} / \mathrm{d}$ throughout the aquifer. For model simulations that represent the least-favorable estimate of average hydraulic conductivity, this value is reduced to $25 \mathrm{ft} / \mathrm{d}$ and for model simulations that represent the mostfavorable estimate the value is increased to $225 \mathrm{ft} / \mathrm{d}$.

(5) Saturated thickness: Ranges generally from about 110 to 190 feet under non-pumping conditions and is relatively uniform throughout the aquifer. In the initial model, the bottom of the aquifer is established at 20 feet above an arbitrary datum. In the revised model, the bottom of the aquifer is changed to zero feet above the datum; thus, the contours shown in figures 4 and 5 indicate the saturated thickness of the hypothetical aquifer as well as the water-table altitude.

(6) Stream characteristics: The bed of the hydraulically-connected stream is 200 feet wide, 2 feet thick, and has a vertical hydraulic conductivity of $3.5 \mathrm{ft} / \mathrm{d}$. The difference in hydraul ic head between the stream and the aquifer, under non-pumping conditions is 1 foot.

(7) Specific yield: Uniform at 0.2 and used only for transient simulations of the revised model.

(8) Flow to, or from, adjacent areas: The initial model of the hypothetical aquifer has till and bedrock along three of its margins and stratified drift along the fourth margin. (See figure 3.) Under average hydrologic conditions and no pumping, the quantity of water that flows from adjacent till and bedrock areas is calculated from the average annual recharge rate for these areas ( $7 \mathrm{in.} / \mathrm{yr}$ ) and an assumed surface area. Flow between the model and stratified-drift areas, as previously discussed, is a function of an assumed average hydraulic gradient, the assigned average hydraulic conductivity of $75 \mathrm{ft} / \mathrm{d}$ and the cross-sectional area along the boundary. The revised model, a smaller part of the initial model, differs from the latter in that it has stratified drift along three of its margins and a stream along the fourth margin. (See figure 3.) Flow to, or from, the revised model and the adjacent areas of stratified drift is also calculated using the average hydraulic gradient along the boundary, the average hydraulic conductivity, and the appropriate cross-sectional area. In the case of the revised model, values for average hydraulic gradient and cross-sectional area along boundaries were obtained from the post-calibration configuration of the initial model. For both initial and revised models, flows between adjacent areas are assumed to be constant for a given recharge-from-precipitation rate, and are distributed uniformly along the model boundaries. When recharge-from-precipitation rates are varied, flows between the models and the adjacent areas are also varied, in proportion. 


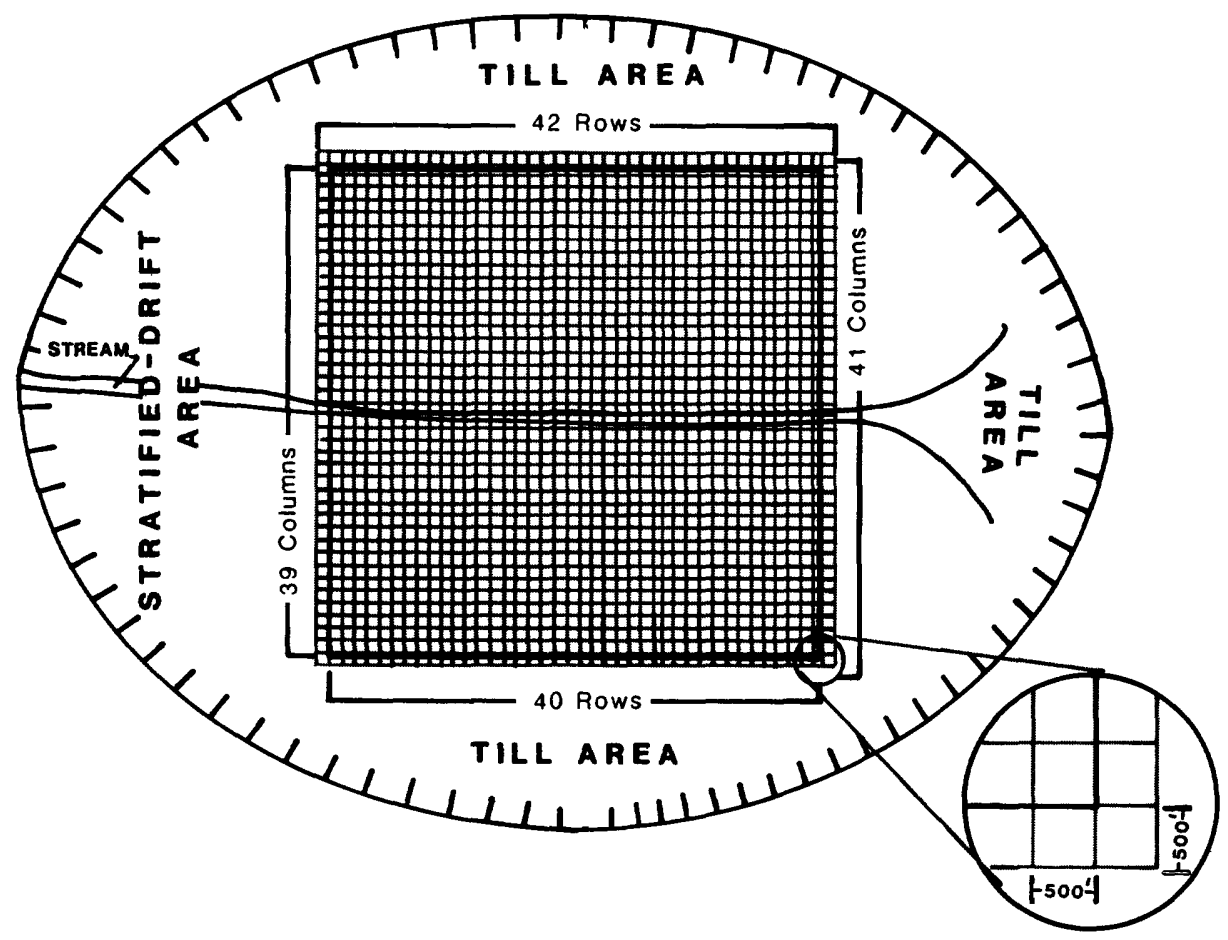

(A) Initial model area and grid.

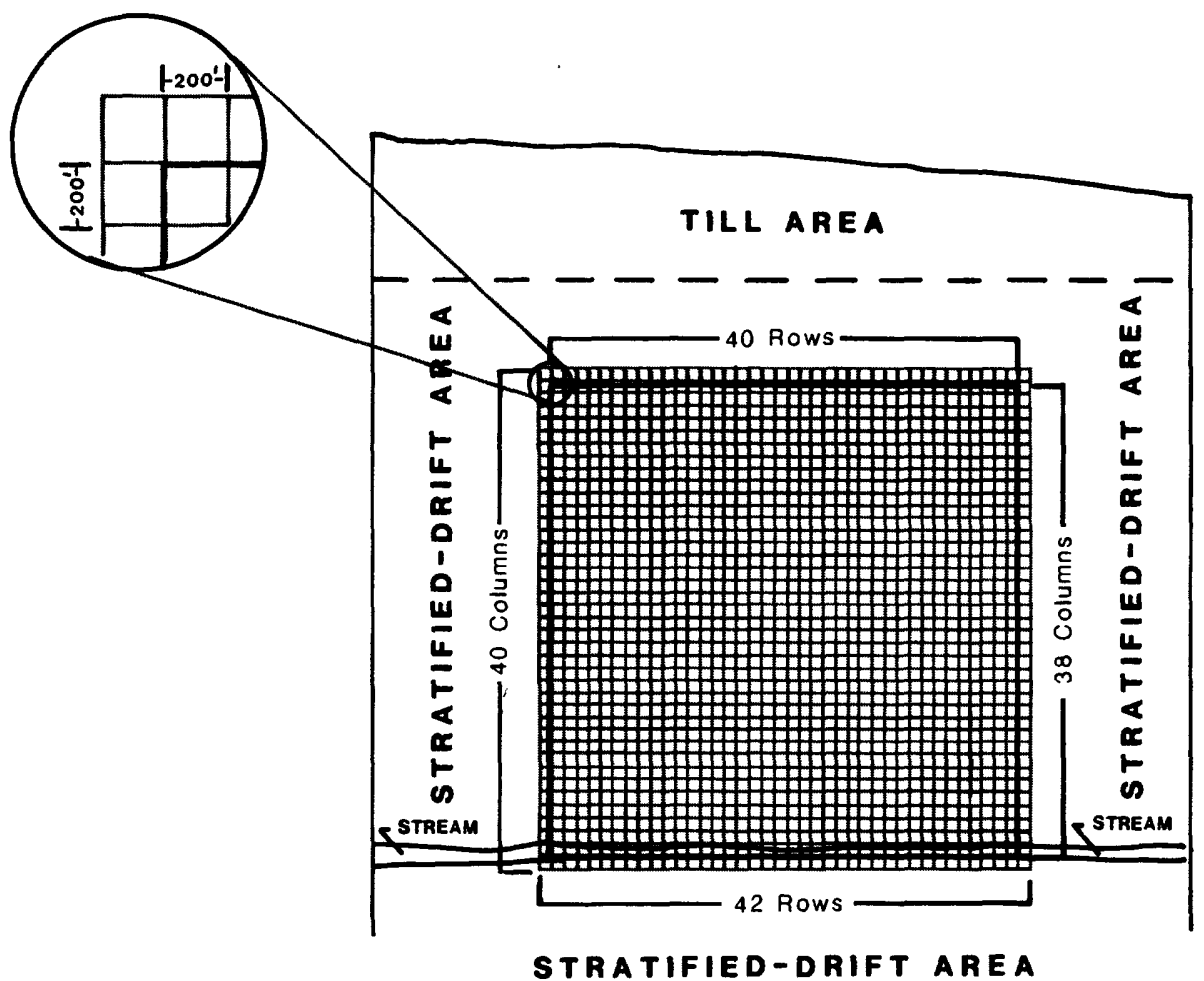

(B) Revised model area and grid.

Figure 3.--The hypothetical-aquifer area showing the initial and revised model grids 
The flow model of the hypothetical aquifer was constructed to represent, in a general way, extensive stratified-drift aquifers that are found in some areas of Connecticut. Because of the relatively large size of these aquifers, and because they typically underlie several towns, it is common practice to model only parts of them. The modeled areas are isolated from the larger stratified-drift body by hydraulic boundaries that approximate natural flow conditions. The initial and revised models of the hypothetical aquifer, discussed below, use two types of flow boundaries: constant-flux boundaries to simulate flow between the modeled area and adjacent areas, and a narrow, leaky, confining bed to simulate flow between the modeled area and the stream. The net effect of these boundaries is to provide the appropriate amount of water available to the modeled part of the aquifer, especially under pumping conditions. As a result, for a given recharge rate, the size of the contributing recharge area that was estimated by model simulation is smaller than it would be if recharge from precipitation on the modeled area were the only source of water. The difference in size of the contributing area that results from the introduction of boundaries is discussed in more detail in the section "Results of the Hypothetical-Aquifer Model Simulations". The shape of the contributing recharge area also is influenced by these boundaries.

Development and construction of the flow model of the hypothetical aquifer proceeded in two phases. Originally, the model represented an area of about $14.0 \mathrm{mi}^{2}$ and had a uniform grid spacing of 500 by 500 feet. This model contains a total of 1,722 nodes ( 42 rows by 41 columns), 1,560 of which represent the hypothetical aquifer. The remaining 162 nodes are blank and are required for mathematical solution of the model. A stream, represented in the model by a narrow, leaky, confining bed, bisects and is hydraulically connected to the aquifer. Till and bedrock upland areas bound three sides of the model area; stratified drift extends beyond the model area on the fourth side. Flow between the model area and these adjacent areas is simulated by constant-flux boundaries. (See figure 3A.) A series of steady-state simulations and adjustments were made to insure that modeldetermined head distribution and allocation of sources and discharges of water were reasonable. The mass balance, determined at the end of this quasi-calibration phase of the initial model, is shown in table 1.

Several of the pumping simulations of the initial model, under steadystate conditions, indicate that the 500-foot grid spacing was too coarse to define the configuration of the water table precisely, particularly in the immediate vicinity of the center of pumping. To overcome this problem, the initial model was modified to provide an improved definition of the water table. The revised model is a section of the initial model, has a finer grid spacing, and covers a smaller area. It contains 1,600 nodes (40 by 40) of which 1,444 represent the aquifer. The grid spacing is 200 by 200 feet and the model extends over an area of about $2.1 \mathrm{mi}^{2}$. In the revised model, shown in figure $3 B$, the stream is moved to the lower margin and is simulated by a narrow, leaky, conf ining-bed boundary. Strat if ied drift adjoins the remaining three sides of the modeled area, and constant-flux boundaries are used to simulate flow between the modeled area and these adjacent areas. Information obtained from the original model, especially saturated thickness and hydraulic gradient, was used to determine the direction of water flows and estimate the magnitude of the constant-flux rates used in the revised model of the hypothetical aquifer. 
Table 1.--Sources and discharges of water determined by initial hypothetical-aquifer model under steady-state conditions

[Values shown assume average hydrologic conditions and no pumpage. They were obtained from the initial version of the hypothetical-aquifer model after calibration. Grid spacing is 500 by 500 feet. Dashed lines indicate no data.]

\begin{tabular}{lcc}
\hline Sources and discharges & $\begin{array}{c}\text { Quantity of water } \\
\text { (million gallons } \\
\text { per day) }\end{array}$ & (inches per year) \\
\hline Sources & & 25.0 \\
Recharge from precipitation & 16.6 & 13.0 \\
Constant flux (into modeled area) & 8.6 & 0.0 \\
Leakage (stream to aquifer) & 0.0 & 0.0 \\
Storage (none for steady-state) & $\underline{0.0}$ & 38.0 \\
Total & 25.2 &
\end{tabular}

Discharges

Leakage (aquifer to stream) $23.0 \quad 34.6$

Ground-water evapotranspiration

Constant flux (out of modeled area)

1.5

2.3

Storage (none for steady-state)

0.7

1.1

$\underline{0.0}$

0.0

Total

25.2

38.0

Net difference (sources less

0.04 discharges)

1/ Values shown in the "inches per year" column use the surface area of the initial model (14.0 square miles) as a common datum.

The mass balance of the revised model, after calibration, is shown in table 2. A comparison of the data in tables 1 and 2 shows that relatively more water ( 13 compared to 33 inches per year) flows into the smaller revised model from adjacent areas than flows into the initial model. This is because (1) the revised aquifer model is bounded by saturated, stratified drift on three of four sides, whereas the initial aquifer model is bounded by saturated stratified drift on one side and by relatively impermeable till on three sides; and (2) the surface area of the revised model, along any section parallel to the stream, is smaller than that of a corresponding section of the initial model. If similar quantities of water flow into these sections, the unit-area flow rate--calculated in inches per year, for example--will be greater for the revised model, because its surface area is smaller. Because of these factors, the areas contributing recharge, as determined by the revised model, are somewhat smaller than are corresponding areas determined by the initial model. 
Table 2.--Sources and discharges of water determined by revised hypothetical-aquifer model under steady-state conditions

[Values shown assume average hydrologic conditions and no pumpage. They were obtained from the revised version of the hypothetical-aquifer model after calibration. Grid spacing is 200 by 200 feet. Dashed lines indicate no data.]

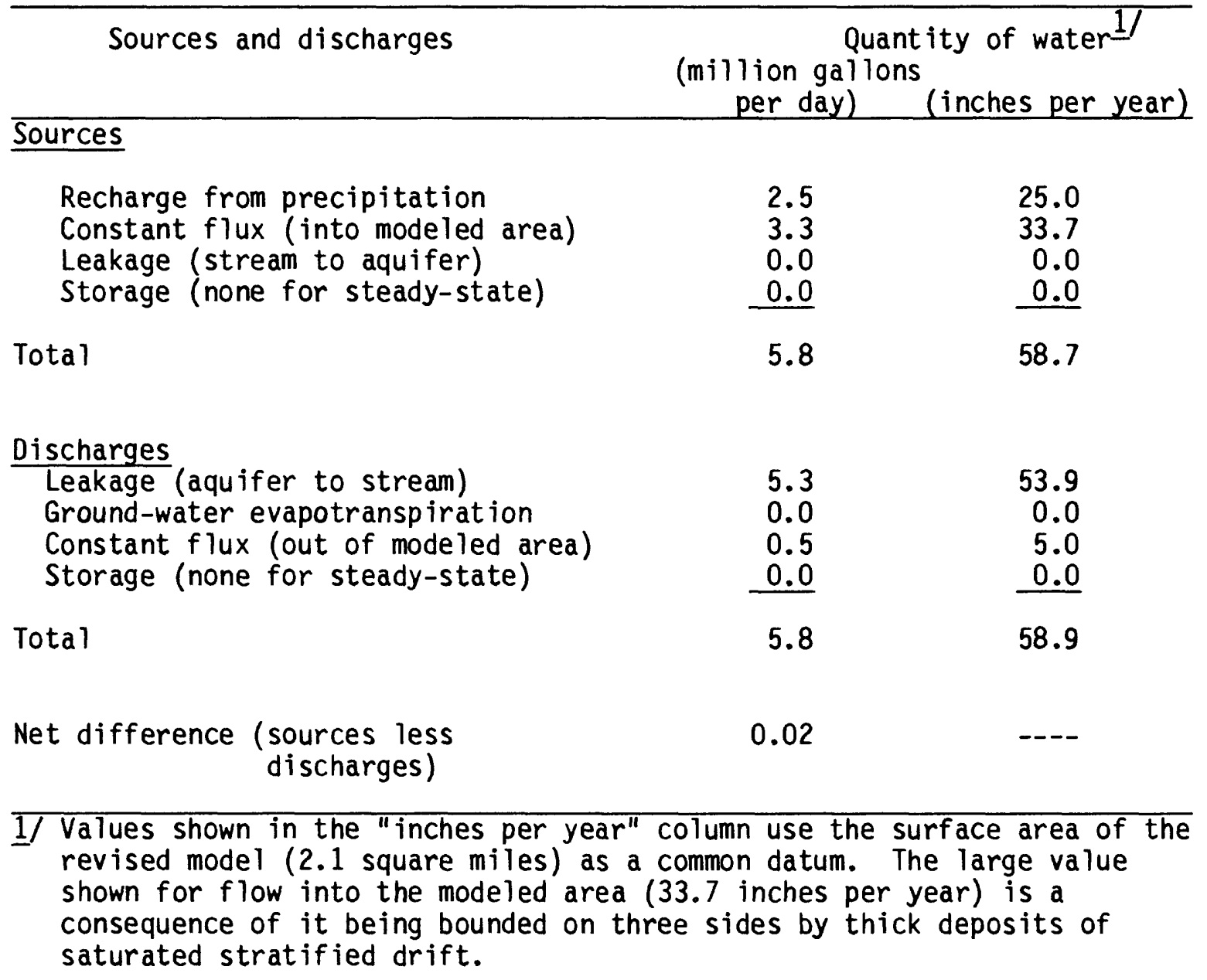

Despite these differences, the revised model reasonably represents a part of the hypothetical aquifer and its use for subsequent evaluations of areas contributing recharge is considered valid. Additional considerations include:

(1) The finer grid spacings of the revised model allow more precise determinations of the configurations of contributing areas.

(2) The use of constant-flux boundaries for the revised model is reasonable since these boundaries allow simulation of large contributions of water to the modeled area and still are far enough from the pumping center to be essentially unaffected by withdrawals. 
(3) Information obtained from the revised model is used only to evaluate a specific technique under restricted conditions. Variations in the size and shape of a contributing area that the revised model determined for specific stress conditions, are intended to be evaluated in relative, not absolute terms.

\section{Simulations by the Hypothetical-Aquifer Model}

Evaluation of the effects that changes in selected hydrologic parameters had on the water-table configuration of the hypothetical aquifer was accomplished in four steps. Each step involved a series of simulations by the model, construction of water-table maps from model-generated data, and evaluation of the significance of the resulting changes in water-table configuration. The four steps are:

(1) A series of preliminary simulations (initial and revised models) was designed to calibrate the models and evaluate their overall performance.

(2) Nine steady-state simulations of the revised model were made, during which a $1.2 \mathrm{Mgal} / \mathrm{d}$ withdrawal was made from a single pumping well while recharge rates and aquifer hydraulic conductivity were varied from least-favorable, to average, to most-favorable conditions.

(3) Nine transient simulations of the revised model were made with the same withdrawal rate and variations in recharge and aquifer hydraulic conductivity, as in step (2).

(4) Three transient simulations of the revised model were made with the same withdrawal rate as in steps (2) and (3). Aquifer hydraulic conductivity was again varied to represent leastfavorable, average, and most-favorable values, but with recharge el iminated.

In step (1), all simulations were run under steady-state conditions, with no pumpage. A recharge rate of $25 \mathrm{in.} / \mathrm{yr}$ and an average aquifer hydraulic conductivity of $75 \mathrm{ft} / \mathrm{d}$ were used. After each simulation, mode 1generated values which included water-table altitudes (head distribution), ground-water outflow (leakage), and the relation between amounts of water entering and leaving the aquifer (mass balance), were examined, and adjustments to model parameters were made as needed. The evaluations and adjustments made during this step are considered to be a quasi-calibration rather than a true calibration of the model, because the aquifer is hypohetical, and actual field data are nonexistent. Parameter values that resulted in the calibration of the initial and revised hypothetical-aquifer models are listed in Appendixes $A$ and $B$.

Adjustments were generally restricted to changes in land-surface altitudes and to adjustments of flow rates across the constant-flux boundaries that link the modeled area to adjacent areas. The sequence of simulation, evaluation, and adjustment was repeated until model-generated water-table altitudes, GWET rate (initial model on $1 y$ ), ground-water outflow, 
and the mass balance were considered reasonable, as judged by the criteria in table 3. The water-table conf iguration of the revised model, obtained at the end of this step, represents an initial reference point. (See fig. 4.) Changes that result from varying recharge rates and hydraulic conduc-tivities, as was done in steps (2), (3), and (4), are compared to this configuration.

Table 3.--Hydrologic elements, requirements, and model-generated values used to evaluate calibration simulations of initial and revised hypotheticalaquifer models

\begin{tabular}{|c|c|c|c|}
\hline \multirow[b]{2}{*}{$\begin{array}{l}\text { Hydrologic } \\
\text { element }\end{array}$} & \multirow[b]{2}{*}{ Requirement } & \multicolumn{2}{|c|}{ Value or remark } \\
\hline & & $\begin{array}{c}\text { Initial } \\
\text { model }\end{array}$ & $\begin{array}{l}\text { Revised } \\
\text { model }\end{array}$ \\
\hline Water table & $\begin{array}{l}\text { Must be below land surface } \\
\text { throughout model area } \\
\text { except at stream. }\end{array}$ & Yes & Yes \\
\hline Water table & $\begin{array}{l}\text { Is within } 5 \text { feet of land surface } \\
\text { only in areas near the stream. }\end{array}$ & Yes & Yes \\
\hline $\begin{array}{l}\text { Ground-water- } \\
\text { evapotrans- } \\
\text { piration rate }\end{array}$ & $\begin{array}{l}\text { Ranges from } 2 \text { to } 7 \text { inches per } \\
\text { year in the initial model. } \\
\text { Not used in the revised model. }\end{array}$ & 2.3 & Not used \\
\hline $\begin{array}{l}\text { Ground-water- } \\
\text { outf low rate }\end{array}$ & $\begin{array}{l}\text { Ranges from } 31 \text { and } 39 \text { cubic } \\
\text { feet per second for the initial } \\
\text { model and from from } 7 \text { to } 9 \\
\text { cubic feet per second for the } \\
\text { revised model. } 1 /\end{array}$ & 35.6 & 8.2 \\
\hline $\begin{array}{l}\text { Mass-balance } \\
\text { difference }\end{array}$ & $\begin{array}{l}\text { Less than 1-percent difference } \\
\text { between recharge and discharge } \\
\text { for both initial and revised } \\
\text { models. }\end{array}$ & 0.16 & 0.26 \\
\hline
\end{tabular}
1/ Ranges given are from 80 to 100 percent of the total amount of water
assumed to be available to each model.

In step (2), a pumping well withdrawing $1.2 \mathrm{Mgal} / \mathrm{d}$ from the aquifer was introduced into the revised model, and nine steady-state simulations were made. Annual recharge rates and hydraulic conductivities were varied to represent least-favorable, average, and most-favorable conditions, as shown in table 4. Maps showing water-table altitudes, prepared after the simulations were completed, were then used to define the size and shape of the area contributing flow to the pumping center. Changes in drawdown at the pumping center and changes in the size of the area contributing flow that result from variations in recharge rates and hydraulic conductivities, under steady-state conditions, are summarized in table 5 . (See table 5, simulations 1-9.) 


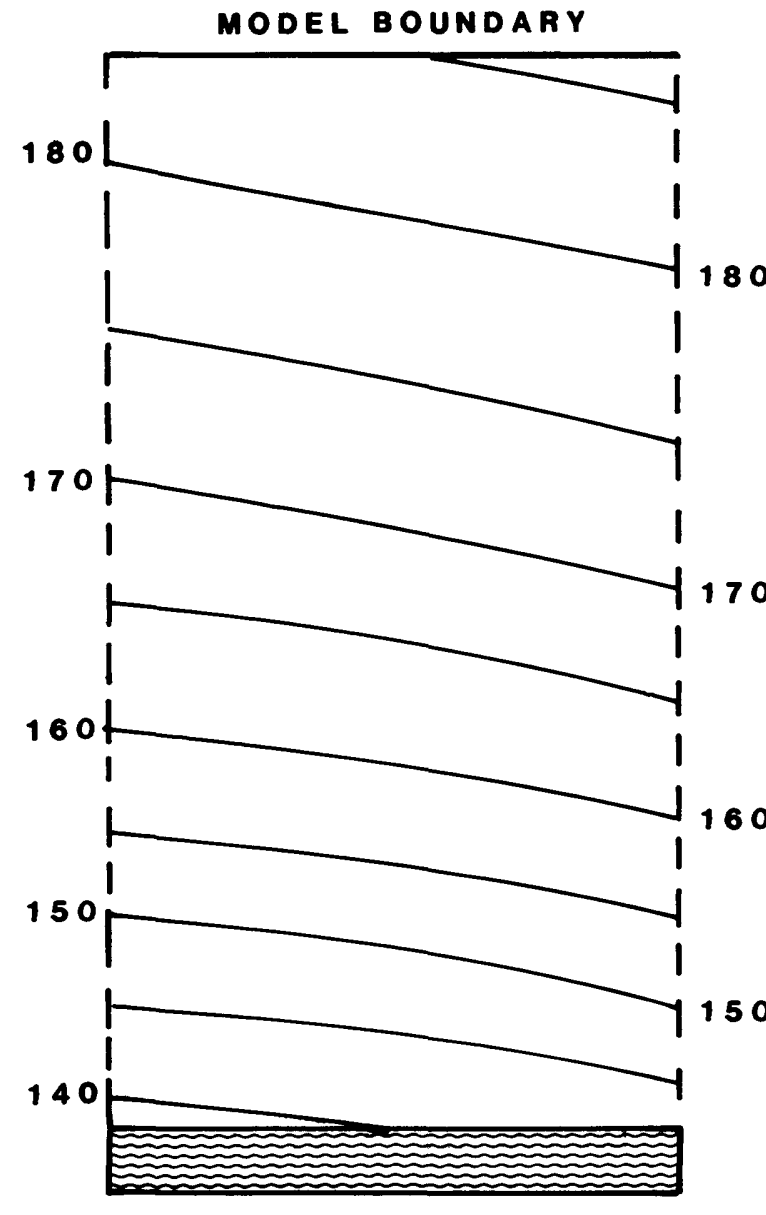

EXPLA N A T IO N

- - SKETCH BOUNDARY--COnstant-flux model boundaries are about 2,000 feet further away.

MODEL BOUNDARY--A constantflux boundary is used to simulate flows from adjacent areas.

MODEL BOUNDARY--A loaky confining bed is used to simulate leakage across the streambed.

-160- WATER-TABLE ALTITUDES--Values are in feet above a common datum of 0.0 feet.

STREAM

SCALE

$\left.\left.\overbrace{0}^{0}\right|_{200} ^{1,000} \frac{2,000}{400}\right|_{600} ^{3,000} \quad 4,000$ Feet

Figure 4.--Water-table altitudes predicted by the hypothetical-aquifer model under average hydrologic conditions, steady-state conditions, and no pumpage 
Table 4.--Recharge rates and hydraulic conductivity values chosen to represent least-favorable, average, and most-favorable conditions acting upon the hypothetical aquifer

\begin{tabular}{lcc}
\hline Condition & \multicolumn{2}{c}{ Hydrologic variable } \\
\cline { 2 - 3 } $\begin{array}{c}\text { Recharge from } \\
\text { precipitation } \\
\text { (inches per year) }\end{array}$ & $\begin{array}{c}\text { Average hydraulic } \\
\text { conductivity } \\
\text { (feet per day) }\end{array}$ \\
\hline Least-favorable & 15 & 25 \\
Average 1 f & 25 & 75 \\
Most-favorable & 35 & 225 \\
\hline
\end{tabular}

If Values used for calibration.

In step (3), the well pumping $1.2 \mathrm{Mgal} / \mathrm{d}$ was retained and nine transient simulations were run. Recharge rates and aquifer hydraulic conductivities were varied as in step (2), but the simulations were run for 180 days. A 180-day time period was selected so that the results of steps (3) and (4) could be directly compared. After the simulations, water-table maps were prepared and contributing areas were delineated. Changes in drawdown at the pumping center and changes in the size of the contributing recharge area that result from variations in recharge rates and hydraulic conductivity values, after 180 days of pumping, are summarized in table 5. (See table 5, simulations 10-18.)

In step (4), three additional 180-day transient simulations were made. A well pumping $1.2 \mathrm{Mgal} / \mathrm{d}$, and aquifer hydraulic conductivity values representing least-favorable, average, and most-favorable conditions were again used, but recharge was eliminated. A 180-day time period was selected because it approximates the duration of the growing season in Connecticut-the longest period in a typical year during which little or no recharge from precipitation is likely to reach the aquifer. Changes in drawdown at the pumping center and changes in the size of the contributing recharge area that result from the variations incorporated in this step are summarized in table 5. (See table 5, simulations 19-21.)

\section{Results of Hypothetical-Aquifer Model Simulations}

In the section of this report titled "Methods of Investigation", it was noted that, under steady-state conditions, the size of the area contributing flow to a pumping center in an idealized aquifer with no boundaries could be estimated with a simple equation that considered only pumping and recharge rates. This simple relationship between contributing areas, pumping rates and recharge rates can be expressed as:

where:

$$
C A=21(Q / R E C H)
$$

$$
\begin{aligned}
C A & =\text { Contributing area in square miles } \\
Q & =\text { Pumping rate in million gallons per day } \\
\text { RECH } & =\text { Recharge to the aquifer in inches per year. }
\end{aligned}
$$


Table 5.--Summary of selected input parameters, drawdowns, and sizes of contributing recharge areas for 21 simulations of the hypothetical-aquifer model under steady-state and transient conditions

[A streambed hydraulic conductivity of 3.5 feet per day and a pumping rate of 1.2 million gallons per day are common to all simulations]

\begin{tabular}{|c|c|c|c|c|c|}
\hline $\begin{array}{c}\text { Simulation } \\
\text { number }\end{array}$ & $\begin{array}{l}\text { Pumping } \\
\text { condition or } \\
\text { duration }\end{array}$ & $\begin{array}{l}\text { Recharge } \\
\text { from } \\
\text { precipitation } \\
\text { (inches per year) }\end{array}$ & $\begin{array}{c}\text { Average } \\
\text { hydraulic } \\
\text { conductivity } \\
\text { of the aquifer } \\
\text { (feet per day) }\end{array}$ & $\begin{array}{l}\text { Maximum } \\
\text { drawdown at } \\
\text { we } 11 \text { node } 1 / \\
\text { (feet) }\end{array}$ & $\begin{array}{l}\text { Size of contributing } \\
\text { recharge area } 2 \\
\text { (square miles) }\end{array}$ \\
\hline 1 & Steady state & 15 & 25 & 35.4 & 0.75 \\
\hline 2 & Do. & 25 & 25 & 29.1 & .64 \\
\hline 3 & Do. & 35 & 25 & 24.1 & .48 \\
\hline 4 & Do. & 15 & 75 & 11.7 & .58 \\
\hline 5 & Do. & 25 & 75 & 9.9 & .48 \\
\hline 6 & Do. & 35 & 75 & 8.5 & .40 \\
\hline 7 & Do. & 15 & 225 & 4.0 & .20 \\
\hline 8 & Do. & 25 & 225 & 3.5 & .18 \\
\hline 9 & Do. & 35 & 225 & 3.0 & .16 \\
\hline 10 & 180 days & 15 & 25 & 26.0 & .69 \\
\hline 11 & Do. & 25 & 25 & 24.7 & .59 \\
\hline 12 & Do. & 35 & 25 & 23.4 & .44 \\
\hline 13 & Do. & 15 & 75 & 9.9 & .50 \\
\hline 14 & Do. & 25 & 75 & 9.2 & .45 \\
\hline 15 & Do. & 35 & 75 & 8.5 & .38 \\
\hline 16 & Do. & 15 & 225 & 3.9 & .19 \\
\hline 17 & Do. & 25 & 225 & 3.5 & .16 \\
\hline 18 & Do. & 35 & 225 & 3.0 & .15 \\
\hline 19 & Do. & 0 & 25 & 27.9 & .70 \\
\hline 20 & Do. & 0 & 75 & 11.1 & .56 \\
\hline 21 & Do. & 0 & 225 & 4.8 & .25 \\
\hline
\end{tabular}


For a pumping rate of $1.2 \mathrm{Mga} 1 / \mathrm{d}$ and recharge rates of 15,25 , and 35 in./ $\mathrm{yr}$, the above relation results in contributing areas of $1.68,1.01$, and $0.72 \mathrm{mi}^{2}$, respectively. However, if flow boundaries are present, the size and shape of these contributing areas will change. The revised model of the hypothetical aquifer represents a common approach to modeling an aquifer that is part of a larger formation; it also includes a hydraulically connected stream. A narrow, leaky, confining bed simulates boundary conditions at the stream and constant-flux boundaries simulate flow between the modeled area and adjacent areas. Water flowing across these boundaries increases the amount of water available in the modeled area, especially under pumping conditions. As a result, contributing areas estimated from data provided by the model are smaller than are contributing areas estimated by the simple recharge-pumping rate relationship. For example, under steady-state conditions with a $25 \mathrm{in.} / \mathrm{yr}$ recharge rate and a $1.2 \mathrm{Mgal} / \mathrm{d}$ pumping rate, the maximum size of the contributing area determined from model data is $0.64 \mathrm{mi}^{2}$. (See table 5, simulation 2.) The recharge-pumping rate estimate, for similar conditions, is $1.01 \mathrm{mi}^{2}$. Stratified-drift aquifers in Connecticut, like the hypothetical aquifer, are not infinite in extent; they are subject to the influences of hydraulic boundaries, and their responses are best simulated by flow models that include such features. The technique of using models of a hypothetical aquifer to estimate contributing-area configurations, as described in this report, provides realistic estimates of the size and approximate shape of these areas.

The first series of nine simulations of the revised model (step 2) was run under steady-state conditions; it used recharge rates of 15,25 , and 35 in./yr in combination with aquifer hydraulic conductivity values of 25,75 , and $225 \mathrm{ft} / \mathrm{d}$. These recharge rates were selected because they fall within the range that approximates natural conditions for Connecticut. The hydraulic conductivities were assumed to represent "average" conditions (75 $\mathrm{ft} / \mathrm{d}$ ) as well as the maximum departures from average (25 and $225 \mathrm{ft} / \mathrm{d}$ ) that might result if the data were unreliable or sparse. These recharge rates and hydraulic conductivities, when combined, form nine unique value-pairs that, in terms of aquifer response, ranged from least-favorable (15 in./yr recharge, $25 \mathrm{ft} / \mathrm{d}$ hydraulic conductivity) to most-favorable conditions (35 in./yr recharge, $225 \mathrm{ft} / \mathrm{d}$ hydraulic conductivity).

After the simulations were run, water-table maps were constructed and the configuration of the area contributing flow to the pumping center was determined for each combination of recharge and hydraulic conductivity. The estimated sizes of the contributing areas for the nine steady-state simulations run in this series and the corresponding drawdowns in the model block containing the well are given in table 5. (See table 5, simulations 1-9.) For average conditions (25 in./yr recharge, $75 \mathrm{ft} / \mathrm{d}$ hydraulic conductivity) the contributing area is $0.48 \mathrm{mi}^{2}$. (See table 5 , simulation 5, and figure 5A.) For other combinations of recharge and hydraulic conductivity, the areas range from $0.75 \mathrm{mi}^{2}$ for least-favorable conditions (15 in./yr recharge, $25 \mathrm{ft} / \mathrm{d}$ hydraulic conductivity) to $0.16 \mathrm{mi}^{2}$ for mostfavorable conditions (35 in./yr recharge, $225 \mathrm{ft} / \mathrm{d}$ hydraulic conductivity). (See table 5, simulations 1 and 9, and figures 5B and 5C.) 

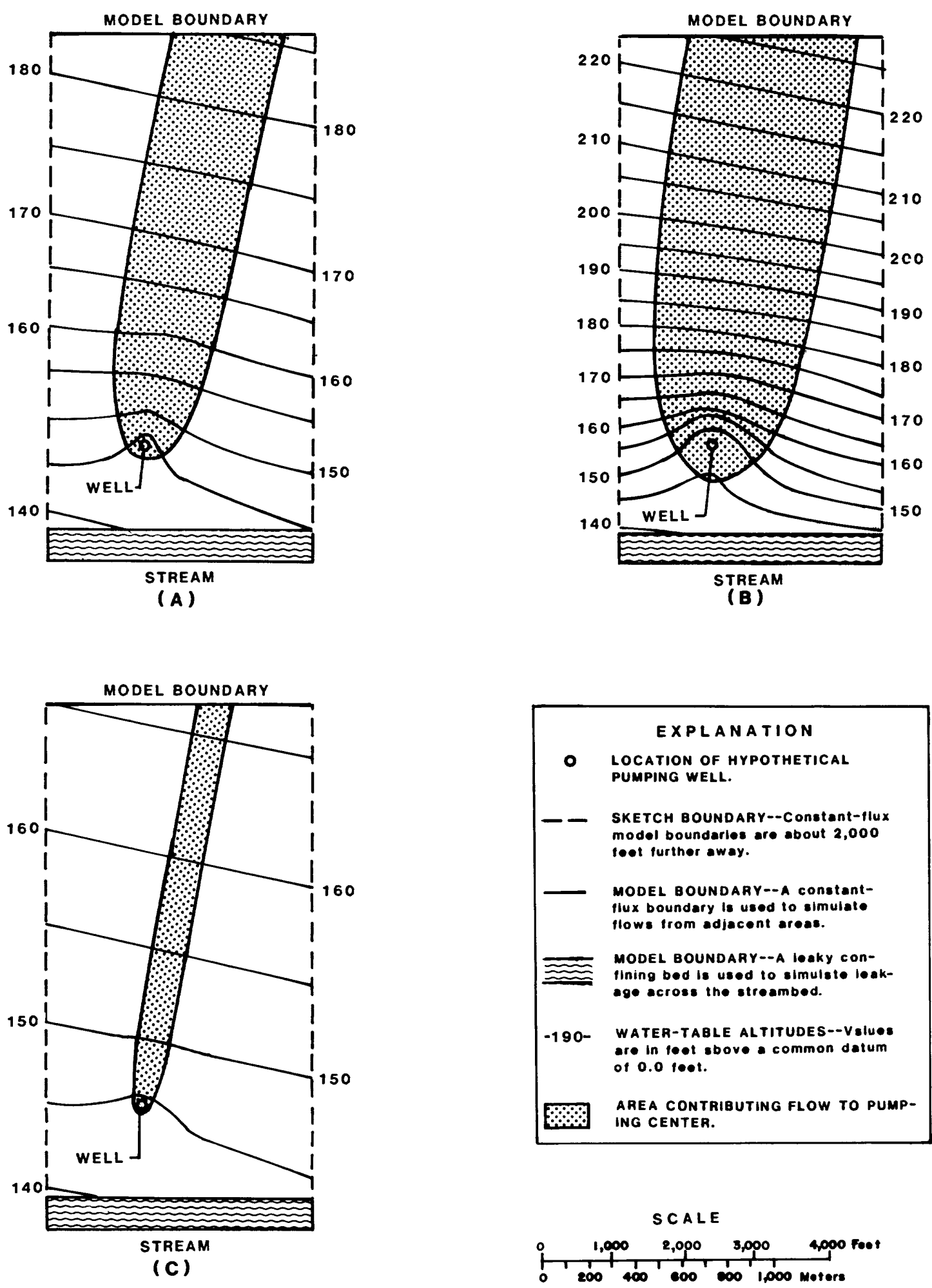

Figure 5.--Water-table altitudes and areas contributing flow to a pumping center predicted by the hypothetical-aquifer model under average (A), least-favorable (B), and most-favorable (C) hydrologic conditions, assuming steady-state conditions and a withdrawal rate of $1.2 \mathrm{Mgal} / \mathrm{d}$ 
The second series of nine simulations (step 3), represents transient conditions. Combinations of recharge and aquifer hydraulic conductivity were identical to those used in the first series of simulations but in the second series, the simulations were run only for a 180-day period. Contributing areas estimated from data provided by these transient simulations were all smaller than their steady-state equivalents, ranging from $0.69 \mathrm{mi}^{2}$ for least-favorable conditions to $0.15 \mathrm{mi}^{2}$ for most-favorable conditions. As a group, the 180-day transient simulations estimated contributing areas that were about 8 percent smaller than those estimated by the steady-state simulations. Drawdowns in the vicinity of the pumping center showed similar decreases--the transient simulations predicted a drawdown about 13 percent less than that predicted by the steady-state simulations. The estimated sizes of the contributing areas for the nine transient simulations run in this series and their corresponding drawdowns are given in table 5 . (See table 5, simulations 10-18.)

The fact that the areas contributing flow to the pumping center are all somewhat smaller for the 180-day, transient simulations than they are for corresponding steady-state simulations indicates that equilibrium conditions have not been reached after 180 days of pumping. If conditions are maintained and pumping is cont inued for a period longer than 180 days, the simulation results suggest that the size of the contributing areas will increase slightly.

The final series of three simulations (step 4), was run for 180 days and assumed that recharge from precipitation was not available. Aquifer hydraulic conductivities representing least-favorable $(25 \mathrm{ft} / \mathrm{d})$, average (75 $\mathrm{ft} / \mathrm{d})$, and most-favorable conditions $(225 \mathrm{ft} / \mathrm{d}$ ) were again used. The boundary conditions for these simulations were the same as those assumed for the previous 180-day transient-model simulations (step 3.) The simulations run in step 4 represent a temporary period of no recharge from precipitation (the growing season), however, water is still able to flow into the modeled part of the aquifer from the stream and from adjacent areas. Sizes of the contributing areas estimated from data provided by these simulations ranged from $0.70 \mathrm{mi}^{2}$ to $0.25 \mathrm{mi}^{2}$ as aquifer hydraulic conductivity was varied to represent conditions that ranged from least-to most-favorable. (See table 5, simulations 19-21.) The sizes of the contributing areas estimated for these three simulations are somewhat greater than those estimated for the transient simulations run in step 2. The latter used the same hydraulic conductivities and 180-day time period, but included a recharge rate of 15 in./yr. (Compare simulations 10 and 19,13 and 20,16 and 21, in table 5.)

Data obtained from the 21 simulations of the hypothetical-aquifer model lead to several conclusions regarding the configuration of the area contributing flow to a pumping center in an unconfined, stratified-drift aquifer with similar hydraulic boundaries. It should be kept in mind that the simulation results and their interpretations are based on the response of a hypothetical aquifer to changes in only two parameters--recharge from precipitation and average hydraulic conductivity--that were varied over specific ranges. The changes in the size and shape of the predicted contributing area are strongly influenced by the numerical values assigned to these aquifer characteristics and by the nature of the hydraulic boundaries selected for the hypothetical aquifer. Thus, they should be 
viewed in relative rather than absolute terms. The following conclusions are appropriate to large stratified-drift aquifers with boundary conditions similar to those of the hypothetical aquifer and are intended to serve as a guide in constructing and evaluating a model of such an aquifer.

The conclusions are:

(1) Variations in recharge and aquifer hydraulic conductivity, over normally experienced ranges, may produce significant changes in the size of the area that contributes flow to a pumping center. Under steady-state conditions, the size of this area increased five-fold as conditions were varied from most-favorable to leastfavorable.

(2) Contributing areas estimated from simulations run under steadystate conditions were, as expected, larger than those estimated from simulations run under 180-day transient conditions. (Compare simulations 1-9 and 10-18 in table 5.) This indicates that simulations under steady-state conditions provide a more conservative (1arger) estimate of the size of the contributing recharge area and may be preferable for aquifer-protection planning purposes.

(3) Contributing areas predicted for 180-day periods with no recharge from precipitation were not much larger than those predicted for 180-day periods with $15 \mathrm{in.} / \mathrm{yr}$ recharge. (Compare simulations 10 and 19,13 and 20,16 and 21, in table 5.) This suggests that, during relatively short periods of little or no recharge (such as the growing season), the small amounts of recharge that may reach the aquifer do not appreciably reduce the size of a contributing area; thus, estimates of this area that are based on a zero recharge rate remain valid.

(4) Other factors, such as specific yield, aquifer anisotropy, and streambed characteristics, also influence the configuration of contributing recharge areas in large stratified-drift aquifers. The affects of these and other hydrologic characteristics on contributing areas, although beyond the scope of the present study, need to be considered in future investigations.

\section{Farmington Aquifer and Model}

\section{Characteristics of the Farmington Aquifer}

The Farmington aquifer is an extensive deposit of saturated stratified drift. It is part of a much larger stratified-drift deposit located in the lower Farmington River valley of central Connecticut. For purposes of this study, the term "Farmington aquifer" refers to the upper, principally coarse-grained part of the deposit located in the Town of Farmington. The Farmington River and a major tributary--the Pequabuck River--traverse this aquifer. The Farmington aquifer consists mostly of coarse-grained 
stratified drift (sand and gravel) interbedded with, and in places overlying, fine-grained stratified drift (very fine sand, silt, and clay). Till and bedrock are found along the eastern and western margins of the aquifer, and stratified drift extends to the north and south beyond the study area. Bedrock underlying the Farmington aquifer consists of interbedded arkose and diabase of Triassic and Jurassic age.

Hydrologic data for this study were obtained from existing reports that describe the Farmington aquifer (Melvin, 1976; Mazzaferro, 1980; Handman and others, 1986). The principal hydrologic characteristics of the Farmington aquifer are:

(1) Recharge from precipitation: Averages from 25 to $30 \mathrm{in./yr}$ over the long term and is distributed fairly uniformly over the aquifer surface.

(2) Hydraulic conductivity: Ranges from near zero to over $300 \mathrm{ft} / \mathrm{d}$. Average hydraulic conductivity in much of the Farmington aquifer ranges from 75 to $100 \mathrm{ft} / \mathrm{d}$.

(3) Saturated thickness: Ranges from a few to more than 125 feet in the coarse-grained, upper section that comprises the aquifer.

(4) Streambed characteristics: The Farmington River crosses the modeled area and averages about 200 feet in width. Average streambed vertical hydraulic conductivity is estimated by the author to be about $2.5 \mathrm{ft} / \mathrm{d}$, and average streambed thickness is about 5 feet. Streambed characteristics of the Pequabuck River--a major tributary to the Farmington River that also crosses the modeled area--are assumed to be similar to those of the Farmington River, although no field data were collected.

(5) Ground-water evapotranspiration: Assumed to occur only in those parts of the study area where the water table is within 5 feet of land surface. The effective, long-term ground-water evapotranspiration rate for the study area is estimated by the author to range from 4 to 8 in./yr.

(6) Principal boundary conditions: Adjacent areas of till, thinly covered bedrock, and stratified drift are separated from the modeled area by constant-flux boundaries. Average flow rates from the $t i 11$ and (or) bedrock areas are the product of the average annual recharge rate for these areas (6 to $8 \mathrm{in./yr}$ ) and the ir areal extent. Average flow rates to or from adjacent stratifieddrift areas are a function of the average hydraulic gradient, average hydraulic conductivity, and cross-sectional area along the boundary.

The Farmington and Pequabuck Rivers are hydraulically connected to the aquifer and receive or contribute water. The streambeds of these rivers, whose characteristics are described in (4), are considered to be specialized boundaries and, in the model, they are simulated as leaky, confining beds. 
(7) Other boundary conditions: Much of the eastern and western parts of the Farmington aquifer are underlain by bedrock and the central part is underlain by extensive deposits of clay and silt. Because only small amounts of water are normally available from these formations, they are treated as no-flow (impermeable-barrier) boundaries.

Description of the Farmington Aquifer Mode 1

The Farmington aquifer mode 1 represents an area of about $20 \mathrm{mi}^{2}$ and generally coincides with the strat ified-drift areas located in the central and western parts of the town of Farmington. The Farmington aquifer model initially used a grid with a uniform, 1,000-foot spacing. Preliminary simulations by this model indicated that the grid spacing did not provide sufficient detail to determine water-table gradients accurately in the vicinity of the pumping center. As a consequence, the grid spacing of the model was changed and, in the immediate vicinity of the pumping center, was reduced to a uniform 200-foot spacing. This resulted in a model grid with a total of 3,024 cells ( 72 columns by 42 rows) with three different dimensions ( 1,000 by 1,000 feet; 1,000 by 200 feet; and 200 by 200 feet). Of the 3,024 cells that comprise the model, 2,109 represent the aquifer; the rest are either located along the margins of the model and are required by the numerical solution (224) or are located outside the area of interest (691). Figure 6 shows the area simulated by the Farmington aquifer model with respect to town boundaries, and the variable grid-spacing arrangement used in the model.

Hydrologic data used in the construction of the Farmington aquifer model were obtained principally from a published report that described the ground-water resources of the Town of Farmington (Mazzaferro, 1980). That report included maps showing the water-table configuration, saturated thickness, and transmissivity distribution of the Farmington aquifer. (See Mazzaferro, 1980, plates B, C, and D.) The present report uses these data directly (water-table map), or indirectly (saturated thickness and transmissivity maps). For example, the altitude of the bottom of the aquifer at a specific point (model node) was estimated by subtracting the saturated-thickness value (Mazzaferro, 1980, plate $C$ ) from the water-table altitude value (Mazzaferro, 1980, plate B). In a similar manner, average aquifer horizontal hydraulic conductivity values at specific points were estimated by dividing the transmissivity value (Mazzaferro, 1980, plate D) by the saturated-thickness value (Mazzaferro, 1980, plate C). Using the above techniques, model inputs for these properties were calculated. Altitude of the bottom of the aquifer, in the modeled area, ranged from about 80 feet above sea level in the thickest part of the aquifer to greater than 400 feet above sea level along the margins. Average aquifer hydraulic conductivity values ranged from 1 to $200 \mathrm{ft} / \mathrm{d}$. 


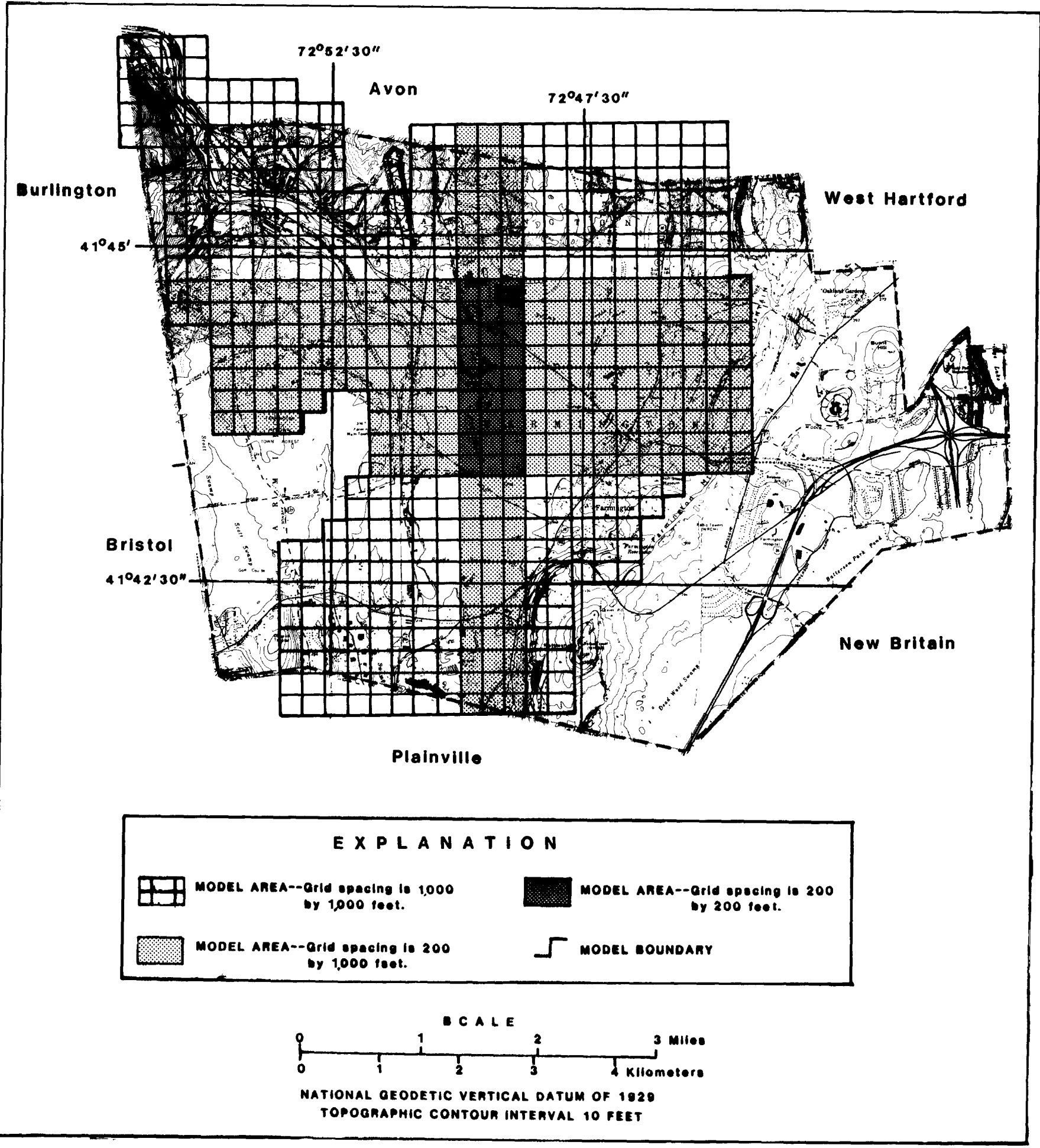

Figure 6.--Boundaries of the Farmington aquifer model and dimensions of the cells in the model grid 
The two large streams that cross the model area, the Farmington and Pequabuck Rivers, either receive water from the aquifer or contribute water to it. In the model, the hydraulic connections between these streams and the aquifer are simulated as leaky confining beds. The hydrologic characteristics of the Farmington River that were used as model input (average stream width, streambed hydraulic conductivity, and average streambed thickness) are discussed in the preceding section. Corresponding values for the Pequabuck River were not available, but they are assumed to be similar to those estimated for the Farmington River. The average head difference between the stream surface and the aquifer, under non-pumping conditions, is estimated to be about 1 foot for both the Farmington and Pequabuck Rivers.

Ground-water flow into the modeled area from adjacent areas of till and thinly covered bedrock is simulated by a series of constant-flux nodes located along the margins of the model. The surface areas of these regions were determined and, when multiplied by the average recharge rate of 7 in./ $\mathrm{yr}$, provided estimates of the total recharge rate in the modeled area. For each area, this rate was then distributed uniformly among the boundary nodes that separated the ti1l-bedrock area from the modeled area. (See figure 7.) Ground-water flow between the modeled area and adjacent areas of stratified drift also is simulated by a series of constant-flux nodes. The average hydraulic gradient across, the estimated hydraulic conductivity at, and the cross-sectional area along these boundaries were used to estimate rates of flow to or from the modeled area. These rates also were distributed uniformly among the appropriate boundary nodes. Bedrock and the finegrained deposits that underlie the model area contribute little water to the aquifer and are considered to act as no-flow boundaries.

As noted above, under average conditions, the recharge rate used to calculate ground-water flow from adjacent areas of till and thinly covered bedrock is $7 \mathrm{in./yr}$. The companion rate for strat ified-drift areas is 30 in./yr. The difference between the two rates reflects the fact that surface-runoff rates in the till-bedrock areas are about three times greater than those in the stratified-drift areas. In addition, the recharge rate estimated for the till-bedrock areas ( $7 \mathrm{in./ \textrm {yr }}$ ) is a net value that considers the effects of ground-water evapotranspiration (estimated to be about 2 to $4 \mathrm{in./yr}$ for till-bedrock areas). For model simulations representing least-favorable and most-favorable recharge conditions, the rates of inflow from the adjacent till and thinly covered bedrock areas use recharge rates

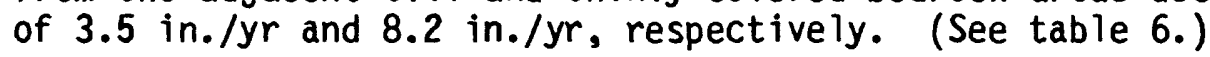

A recharge rate of $30 \mathrm{in./yr}$, as noted in table 6 , was used as an average in areas of stratified drift; this rate also was used for mode 1 calibration. The $30-\mathrm{in.} / \mathrm{yr}$ rate is somewhat higher than the rate estimated from long-term precipitation records $(26 \mathrm{in./ \textrm {yr }})$; however, the higher value was used to calibrate the model because, during the 1974-76 period, precipitation in the Farmington area averaged $53.6 \mathrm{in.} / \mathrm{yr}$, which is about 8.7 inches above norma 1. As a consequence, water-level data collected in 1976 and used to calibrate the model reflect a somewhat wetter-than-average period. 


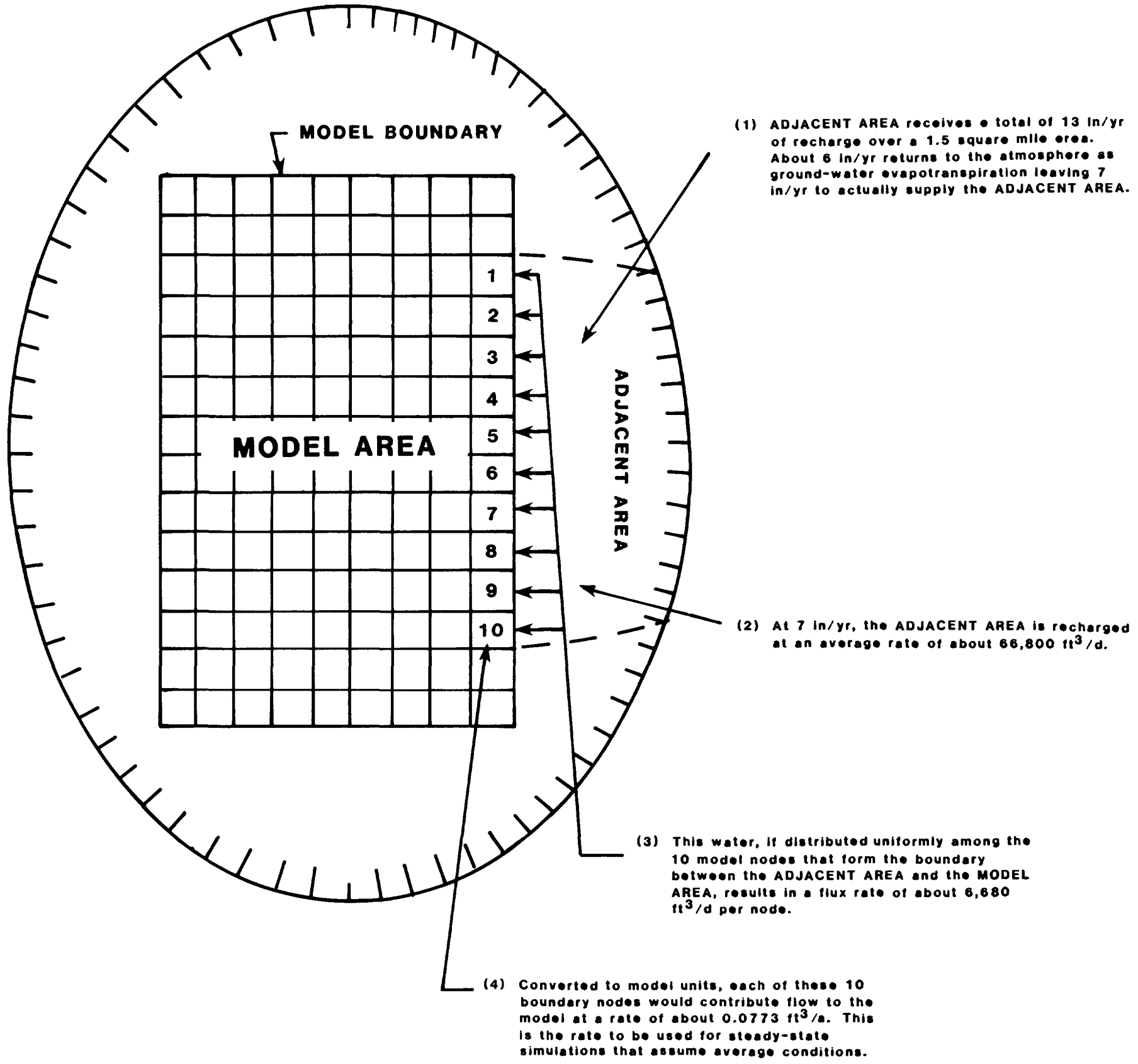

Figure 7.--An idealized aquifer model area showing how flow from an adjacent area is apportioned over 10 boundary nodes

The recharge rates in stratified-drift areas that represent leastfavorable (15 in./yr) and most-favorable ( $35 \mathrm{in./yr}$ ) conditions are estimates based on the annual precipitation extremes that might reasonably be expected in the area. These values consider 3-year periods of lowest and highest total precipitation during the 1931-79 period of record and assume that recharge is generally proportional to precipitation. All recharge rates are assumed to be uniform over the modeled area. 
Table 6.--Recharge rates and hydraulic conductivity factors selected to represent least-favorable, average, and most-favorable conditions affecting the Farmington aquifer

Recharge from precipitation

\begin{tabular}{ccc} 
Stratified- & Till and & $\begin{array}{c}\text { Aquifer horizontal } \\
\text { hydraulic conductivity }\end{array}$ \\
Hydrologic & $\begin{array}{c}\text { drift areas bedrock areas } 1 / \\
\text { conditions }\end{array}$ (inches per year)(inches per year) & (dimensionless) \\
\hline
\end{tabular}

Least-favorable $\quad 15$

15

3.5

0.33

Average

30

7.0

1.00

Most-favorable

8.2

3.00

$1 /$ Values used to estimate amount of recharge from adjacent areas.

2/ Average values (1.00) are multiplied by either a least-favorable or most-favorable (3.00) factor to represent these conditions.

The hypothetical pumping center chosen for the model is located in an area of thick, saturated stratified drift. It generally coincides with an area ident if ied as favorable for the development of ground water (Model Area No. 2) in an earlier report (Mazzaferro, 1980) and is near the Farmington River. The location of the pumping center and the three hypothetical wells used to withdraw water from the aquifer are shown on plates B, C, and D. Other areas capable of yielding large amounts of water have been identified in the stratified-drift deposits in Farmington. These include two areas investigated by Mazzaferro (1980) and an area in the southwestern part of the town (J.A. Thompson, Buck \& Buck Engineers, oral commun., 1982). The effects of large-scale ground-water withdrawals on the configurations of contributing areas at these locations were not investigated during the course of the present study.

\section{Simulations by the Farmington Aquifer Mode 1}

Simulations by the Farmington aquifer model included an initial series of runs to calibrate the model and a final series to evaluate the response of the aquifer to changes in selected input parameters. Descriptions of these simulations and evaluations follow.

The initial series of simulations was conducted under steady-state conditions and assumed no pumpage. These simulations were used to evaluate the response of the model and to refine it to a point where predicted head distributions were reasonable and generally in agreement with water-level data collected in 1976. The procedure consisted of a series of simulations and parameter adjustments followed by evaluations of the head distribution as determined by the model. The evaluation of head distribution used an existing map of water-table altitudes (Mazzaferro, 1980, plate B) as a bas is of comparison (see fig. 8). Adjustments to initial mode 7 input parameters were 1 imited to minor (1ess than 10 percent) changes in aquifer hydraulic conductivity, aquifer thickness, and flow across constant-flux boundaries. 
Mode 1 input was adjusted if model-generated water-table altitudes were significantly different from field values. Changes to initial model-input values were mainly confined to areas along the eastern and western margins where data were sparse or absent, and were guided by two criteria: (1) the values had to fall within a range considered realistic for the study area and (2) the values had to be in agreement with reliable data from nearby areas. The final parameter values used in the Farmington aquifer model are listed in Appendix C.

After each set of simulations and adjustments, the water-table altitudes generated by the model were compared to the existing water-table map (Mazzaferro, 1980). The comparison extended over the entire area covered by the model, but special attention was given to the most-favorable part containing the pumping center. This area, shown in figure 8 , is considered to be favorable for ground-water development and is capable of yielding as much as $1,000 \mathrm{gal} / \mathrm{min}$ (gallons per minute) to individual wells (Mazzaferro, 1980). When the water-table configuration as determined by the model (fig. 9) approximated that of the the existing water-table map

(fig. 8), the initial phase was completed. The mass balance, determined at the end of this quasi-calibration phase, is shown in table 7. Although this process is not intended to be a formal or rigorous model calibration, it is considered to be adequate, provided use of the model is limited to the purposes discussed in this report.


Figure 8.--Water-table altitudes in the most-favorable part of the Farmington aquifer, November 30 to December 1, 1976, under wetter-than-average conditions 
Table 7.--Sources and discharges of water determined by the Farmington aquifer model under steady-state conditions

[Values shown assume average hydrologic conditions and no pumpage. They were obtained from the Farmington aquifer model after calibration. Grid spacing is variable. Dashed lines indicate no data.]

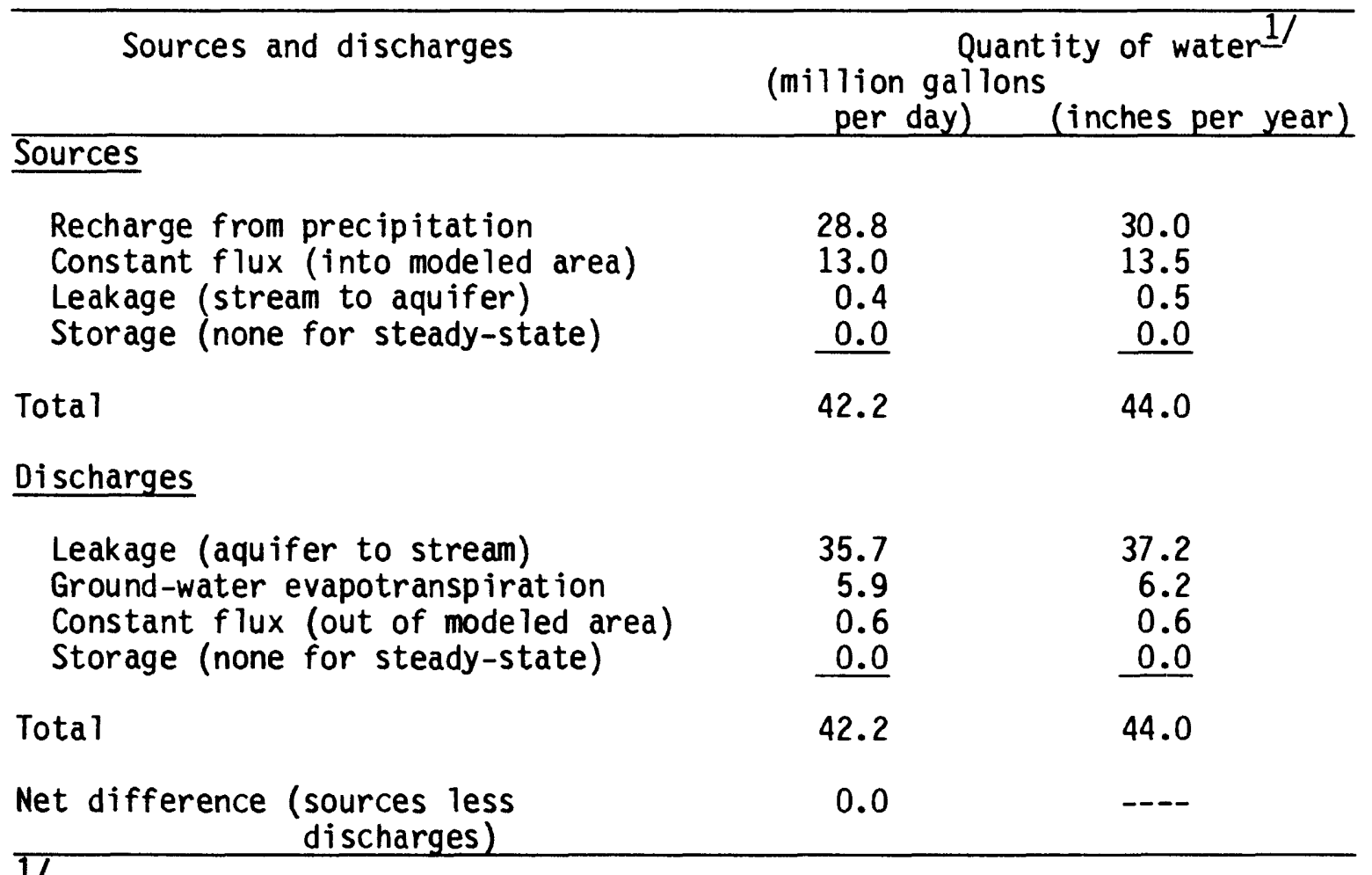

1/ Values shown in the "inches per year" column use the surface area of the Farmington aquifer model (20 square miles) as a common datum.

Evaluation of the response of the Farmington aquifer to large changes in recharge and aquifer hydraulic conductivity was based on three simulations, run under steady-state conditions. During these simulations, combinations of recharge and aquifer hydraulic conductivity were selected to represent least-favorable, average, and most-favorable hydrologic conditions, and a pumping center with three hypothetical wells withdrawing about $2.85 \mathrm{Mgal} / \mathrm{d}$ was introduced. (See plates B-D for the locations of the three wells.) This pumping rate is estimated to be the long-term rate that can be maintained at this site under average hydrologic conditions. It generally agrees with the maximum long-term pumping rate of $2.5 \mathrm{Mgal} / \mathrm{d}$ determined for the area in an earlier study that used an analytical model operating for a 180-day pumping period during which there was no recharge (Mazzaferro, 1980). The original plan was to maintain the same individual pumping rate at each of the three wells during the model simulations. However, this was not possible because, under least-favorable conditions, drawdown at hypothetical well 3 was excessive. In order to maintain the desired combined pumping rate under least-favorable conditions, well 3 was pumped at a reduced rate, while wells 1 and 2 were pumped at increased rates. In this manner, a combined pumping rate of about $2.85 \mathrm{Mgal} / \mathrm{d}$ was possible for all simulations. It is assumed that the size and shape of the area contributing flow to the center of pumping is not greatly affected by these adjustments. The pumping rates of the individual wells that were used during each of the model simulations are shown in table 8 . 
Table 8.--Pumping rates for three hypothetical wells tapping the Farmington aquifer used in simulations of the aquifer model that represent least-favorable, average, and most-favorable hydrologic conditions

\begin{tabular}{|c|c|c|c|}
\hline \multirow[b]{2}{*}{$\begin{array}{l}\text { Hypothetical } \\
\text { well number }\end{array}$} & \multicolumn{3}{|c|}{$\begin{array}{l}\text { Pumping rates used in simulations of the } \\
\text { Farmington aquifer model that assumed the } \\
\text { hydrologic conditions indicated } \\
\text { (gallons per minute) }\end{array}$} \\
\hline & $\begin{array}{l}\text { Least- } \\
\text { favorable }\end{array}$ & Average & $\begin{array}{c}\text { Most- } \\
\text { favorable }\end{array}$ \\
\hline $\begin{array}{l}1 \\
2 \\
3\end{array}$ & $\begin{array}{l}898 \\
898 \\
180\end{array}$ & $\begin{array}{l}785 \\
785 \\
404\end{array}$ & $\begin{array}{l}785 \\
785 \\
404\end{array}$ \\
\hline $\begin{array}{l}\text { Total pumpage } \\
\text { Total pumpage, in } \\
\text { million gallons per day } \\
\end{array}$ & $\begin{array}{r}1,976 \\
2.85 \\
\end{array}$ & $\begin{array}{r}1,974 \\
2.84 \\
\end{array}$ & $\begin{array}{r}1,974 \\
2.84 \\
\end{array}$ \\
\hline
\end{tabular}

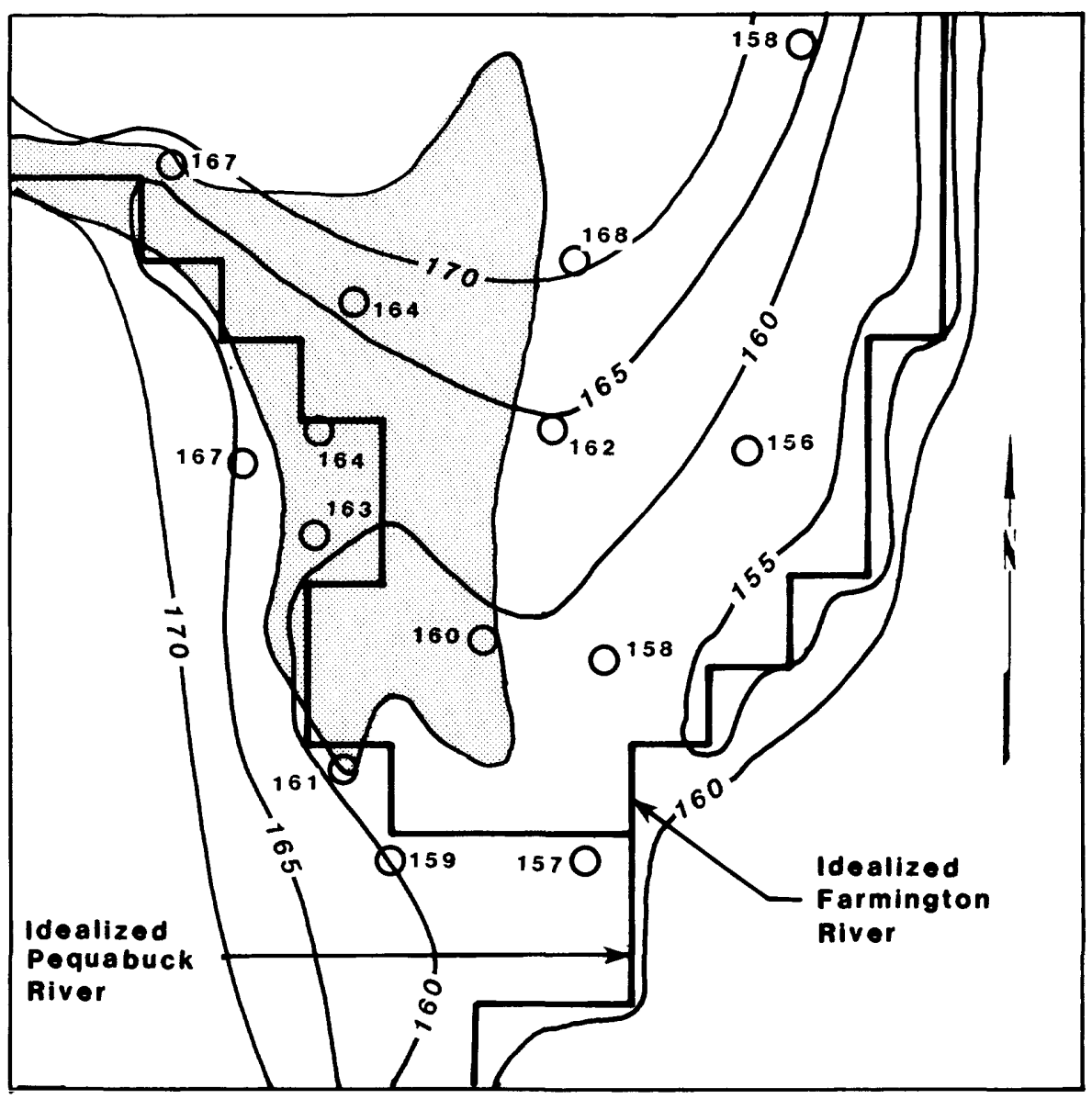

EXPLANATION

AREA MOST FAVORABLE FOR
GROUND-WATER DEVELOPMENT

-160- WATER-TABLE ALTITUde--Values are In toet above sea level. Interval 5 teet.

$0^{158}$

OBSERVATION WELL--VaLUE ARe

woter-table altitude. In toet above sea level.

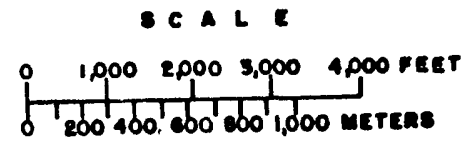

Figure 9.--Simulated water-table altitudes in part of the Farmington aquifer as determined by model simulation 
The recharge rates used in the three simulations of the Farmington aquifer model are assumed to represent a range in annual rates that occurs in response to long-term variations in precipitation. The aquifer hydraulic conductivity values used in the simulations are assumed to represent a range that might result from the imprecise definition of this aquifer characteristic. Hydraulic conductivities used to calibrate the model are considered to be "true" values and are defined as the hydraulic conductivities representing "average" hydrologic conditions. Multiplication factors, used to adjust hydraulic conductivity to represent least-favorable $(0.33)$ and mostfavorable conditions (3.0), establish a range that compensates for the inability to define this parameter precisely--a condition that commonly results from missing, sparse, or unevenly distributed data.

Data obtained from simulations of the hypothetical-aquifer model, presented earlier in this report, show that the contributing area estimated for theoretical, long-term, least-favorable conditions, (steady-state simulation, $25 \mathrm{ft} / \mathrm{d}$ hydraulic conductivity, $15 \mathrm{in} . / \mathrm{yr}$ recharge) is slightly larger than the contributing area estimated for the most severe natural condition (180-day transient simulation, $25 \mathrm{ft} / \mathrm{d}$ hydraulic conductivity, no recharge). (Compare simulations 1 and 19 , table 5.) Thus, if a pumping rate of $2.85 \mathrm{Mgal} / \mathrm{d}$ represents maximum development in this part of the Farmington aquifer, then the contributing area that results from this withdrawal rate, under steady-state conditions and least-favorable conditions (see plate B) probably exceeds the largest that would develop under most drought conditions.

\section{Results of Farmington Aquifer Model Simulations}

After calibration, four steady-state simulations of the Farmington aquifer model were run. These simulations represented average hydrologic conditions with no pumpage and average, least-favorable, and most-favorable hydrologic conditions with pumpage. When the simulations were completed, maps showing the predicted configurations of the water table in the study area were prepared. The four simulations are summarized below:

(1) Average conditions--30 in./yr recharge, field hydraulic conductivity, no pumpage. (See plate A.)

(2) Least-favorable conditions--15 in./yr recharge, field hydraulic conductivity multiplied by an adjustment factor of 0.33 , a center of pumping with a withdrawal rate of $2.85 \mathrm{Mgal} / \mathrm{d}$. (See plate B.)

(3) Average conditions--30 in./yr recharge, field hydraulic conductivity, a center of pumping with a withdrawal rate of 2.84 Mgal/d. (See plate C.)

(4) Most-favorable conditions--35 in./yr recharge, field hydraulic conductivity multiplied by an adjustment factor of 3.0 , a center of pumping with a withdrawal rate of $2.84 \mathrm{Mgal} / \mathrm{d}$. (See plate D.) 
The size and shape of the area contributing recharge to the pumping center was then determined for each of the simulated hydrologic conditions. The configurations of these areas were estimated from water-table altitudes obtained from the model. The configurations of these areas are shown on plates B, C, and D; their areas are given in table 9.

The data show that the size of the contributing area changed by about 50 percent as conditions were varied from least-favorable to most-favorable, decreasing from $1.94 \mathrm{mi}^{2}$ to $0.89 \mathrm{mi}^{2}$. The shape of the area remained generally the same, but it expanded and contracted in response to the imposed changes in recharge and aquifer hydraulic conductivity. Under average conditions, the size of the contributing area, as determined by data from the model, was $1.37 \mathrm{mi}^{2}$. It increased 42 percent (to $1.94 \mathrm{mi}^{2}$ ) as hydrologic conditions became less favorable, and decreased 35 percent (to $0.89 \mathrm{mi}^{2}$ ) as they became more favorable. Table 9 lists the recharge rates, hydraulic-conductivity multiplication factors, and sizes of contributing areas for the three conditions simulated.

Table 9.--Summary of data from three steady-state simulations of the Farmington aquifer model

[All simulations assume three wells with a combined pumping rate of about 2.8 million gallons per day]

\begin{tabular}{|c|c|c|c|c|c|c|}
\hline $\begin{array}{l}\text { Simulation } \\
\text { number }\end{array}$ & $\begin{array}{l}\text { Hydrologic } \\
\text { condition }\end{array}$ & $\begin{array}{l}\text { Recharge } \\
\text { from } \\
\text { precipitation } \\
\text { (inches per year) }\end{array}$ & $\begin{array}{l}\text { Hydraulic } \\
\text { conductivity } \\
\text { range } \\
\text { (feet per day) }\end{array}$ & $\begin{array}{l}\text { Hydraulic } \\
\text { conductivity } \\
\text { multiplication } \\
\text { factor } \\
\text { (dimensionless) }\end{array}$ & $\begin{array}{l}\text { Maximum } \\
\text { drawdown } \\
\text { at well } \\
\text { location } 1 / \\
\text { (feet) }\end{array}$ & $\begin{array}{l}\text { Size of } \\
\text { contributing } \\
\text { recharge area } 2 / \\
\text { (square miles) }\end{array}$ \\
\hline 1 & Least-favorable & 15 & $0.5-80$ & 0.33 & 58.2 & 1.94 \\
\hline 2 & Average & 30 & $1.0-250$ & 1.00 & 9.4 & 1.37 \\
\hline 3 & Most-favorable & 35 & $3.0-750$ & 3.00 & 7.4 & .89 \\
\hline
\end{tabular}

The maximum aquifer drawdown determined for each simulation is also listed in table 9. This value is the average water-table decline in the 200 by 200 foot mode 1 cell that, for a particular simulation, contains the hypothetical well with the greatest drawdown. Maximum drawdowns range from 7.4 feet for most-favorable conditions to 58.2 feet for least-favorable conditions. The large drawdown value determined for least-favorable conditions indicates that, under these conditions, a withdrawal rate of 2.85 $\mathrm{Mgal} / \mathrm{d}$ is probably not feasible using only three wells. Under leastfavorable conditions, a withdrawal rate of this magnitude may be possible but would require additional wells, different spacings, and different pumping rates. These changes would probably alter the size and shape of the area contributing flow to the pumping center, and if significant, the changes could require additional model simulations and analyses. Such work is beyond the scope of the present study. 
A mass-balance comparison or summary of the sources and discharges of water, as determined by the Farmington aquifer model under variable hydrologic conditions, is shown in table 10. These data were obtained from the steady-state simulations by the Farmington aquifer model that included pumpage. As previously discussed, recharge from precipitation and aquifer hydraulic conductivity were varied so that least-favorable, average, and most-favorable conditions were approximated for these parameters. Table 10 shows that recharge from precipitation is the most important source of water for the Farmington aquifer. As model parameters were changed to represent different hydrologic conditions, the quantity of water supplied to the aquifer as recharge from precipitation remained proportionally similar, ranging from about 63 to 66 percent of the total. Flows into the aquifer from adjacent areas also were a significant source of water, comprising approximately 28 to 30 percent of total sources; they too remained proportionally similar as hydrologic conditions were varied from least-favorable to most-favorable. Water entering the aquifer as leakage from the Farmington or Pequabuck River was the third major component and amounted to 8.8 percent of total supply for least-favorable conditions, 4.0 percent for average conditions, and 5.0 percent for most-favorable conditions.

Table 10.--Sources and discharges of water determined by the Farmington aquifer model under pumping conditions

[Least-favorable, average, and most-favorable conditions for recharge from precipitation and aquifer hydraulic conductivity are assumed. Steadystate conditions are simulated with a combined pumping rate of about 2.8 million gallons per day, from three wells.]

\section{Hydrologic condition}

$\begin{array}{ll}\text { Sources and discharges } & \begin{array}{l}\text { Least- } \\ \text { favorable Average favorable }\end{array}\end{array}$

Quantity of water $1 /$

(inches per year)

\section{Sources}

Recharge from precipitation

Constant flux (into modeled area)

Leakage (stream to aquifer)

Total

Discharges

Leakage (aquifer to stream)

Ground-water evapotranspiration

Pumpage (three hypothetical wells)

Constant flux (out of modeled area)

\begin{tabular}{rrr}
15.0 & 30.0 & 35.0 \\
6.7 & 13.5 & 15.8 \\
2.1 & 1.8 & 2.7 \\
\hline
\end{tabular}

$23.8 \quad 45.3 \quad 53.5$
Tota 1

15.3

5.2

3.0

0.3

23.8

45.3

35.7

6.0

3.0

0.6

5.1

3.0

0.7

$1 /$ Amounts of water shown are in inches per year and use the surface area of the Farmington aquifer model (20 square miles) as a common datum. 
Discharge data, also shown in table 10 , indicate that as hydrologic conditions were varied from least-favorable to most-favorable, leakage to the stream became an increasingly important component of discharge, increasing from 63 to 84 percent of the total. Over the same variation in hydrologic conditions, discharges by ground-water evapotranspiration showed the opposite trend, declining from 22 percent of the total under leastfavorable conditions to about 9.5 percent of the total under most-favorable conditions. The combined pumping rate of the hypothetical wells withdrawing water from the aquifer was kept constant for all simulations and, as a consequence, the discharge from this activity was relatively most important under least-favorable conditions, amounting to 13 percent of the total. Under average and most-favorable conditions, discharges of water due to pumping amounted to 6.6 percent and 5.6 percent of total discharge, respectively. Under a 11 hydrologic conditions, amounts of water discharging from the aquifer to adjacent areas were relatively minor, averaging from 1 to 2 percent of the total.

\section{DATA REQUIREMENTS AND APPLICATION OF THE TECHNIQUE TO OTHER AREAS}

Use of a digital flow model to investigate the size and shape of the area contributing flow to a pumping center in other aquifers in Connecticut requires the consideration of two primary factors: (1) the adequacy of hydrologic data in the area of investigation and (2) the level of accuracy considered acceptable for a particular application.

These factors are closely related, because a considerable amount of hydrologic data is needed to construct and calibrate a representative model of a stratified-drift aquifer. In theory, error-free input data and exact mathematical solutions will permit simulations that exactly reproduce the response of the natural system. In practice, however, such perfection is never achieved and the process of constructing a model and evaluating its output becomes a series of reasonable compromises and assumptions. During all phases of the modeling process, it is important to understand that final results depend upon both the reliability of existing information and how it is incorporated in the model.

Considerably more data are available for the Farmington aquifer than for most other large stratified-drift aquifers in Connecticut. Several earlier investigations have dealt with all or part of the area covered by the present study. Products of these earlier efforts include (1) maps showing configuration of the water table in the study area, (2) maps showing aquifer characteristics including transmissivity and saturated thickness, and (3) analytical evaluations of the amounts of ground water practically available for development (Randa 11, 1964a; Melvin, 1976; Mazzaferro, 1980; Handman and others, 1986). These data facilitated the construction of the Farmington aquifer model and permit some general conclusions regarding the feasibility of using such models for similar investigations.

If the digital-modeling methods described in this report are used to evaluate areas contributing flow to pumping centers in other stratifieddrift aquifers in Connecticut, a series of questions relative to the data available for an area, the existing or planned development of the aquifer, and the type of model under consideration must be addressed early in the study. These elements are discussed in more detail below. 
The adequacy of available hydrologic data is a key element in the decision to construct a digital flow model and to use it as an investigative tool. The term "adequate", when applied to hydrologic data, must consider the accuracy required of the final product as well as the accuracy and completeness of the data. In the construction of the Farmington aquifer mode 1 and in the evaluation of the simulations, the following data elements were considered to be most important. Their relative ranking (greater to lesser importance) is based on (1) the ability of the model to represent the aquifer and (2) the sensitivity of the model to changes in specific parameters, especialiy as they affect head distribution.

(1) Water-table altitude: This element is ranked highest because it is related to many other elements needed to construct and evaluate a model. Water-table altitudes indicate recharge and discharge areas and the direction of ground-water flow. They influence the amount of ground water that will be discharged by evapotranspiration and define the upper limit of the aquifer. The altitude of the water table also is the principal item used to calibrate the model and evaluate how closely it represents the natural system.

(2) Altitude of the bottom of the aquifer: This element provides information on the third dimension of the aquifer. In combination with water-table altitude, it determines saturated thickness.

(3) Boundary conditions: These data elements determine the physical limits of the aquifer and may have a significant influence on the altitude of the water table as the aquifer is stressed. In general, the more distant the boundary, the smaller is its effect on water-table altitudes. Boundary conditions may also have a considerable influence on the configuration of a contributing recharge area, and in theory, information relative to their location and type could be ranked higher. In practice, however, accurate data regarding boundary conditions commonly are difficult to obtain and reasonable assumptions must be substituted.

(4) Streambed characteristics: In the mode1, streams are simulated as special types of boundaries and the same comments as in item 3 apply. Under certain conditions of development, streambed characteristics may become relatively more important, because it is accepted practice to locate production wells close to streams in order to increase yields.

(5) Aquifer characteristics (average hydraulic conductivity, specific yield): These items are ranked relatively low in importance because exact determinations usually are not available for much of the modeled area. However, estimates based on existing data are generally available and they permit the mode 1 to represent the aquifer reasonably. If these estimates are conservatively biased, the areas contributing ground-water flow that are determined from model simulations will likely be greater than actual values. 
(6) Recharge from precipitation: These data have the lowest relative importance because reasonable estimates of long-term, average recharge and variations in recharge are available statewide. Also, because recharge rates are varied over relatively broad ranges to simulate natural fluctuations in this characteristic, precise, site-specific values are not needed.

Another item that must be evaluated prior to the construction of a model is the proposed plan of development of the aquifer under investigation. At a minimum, data must be available that specifies, or allows the determination of :

(1) Location of pumping centers in the aquifer: This may be an existing well field, an area considered to be most favorable for ground-water development because of hydrologic considerations or an area selected for political, economic, or other reasons.

(2) Anticipated withdrawal rate: Some information must be acquired relative to present and future long-term pumping rates that are expected when the aquifer is developed. If maximum withdrawal rates are assumed, a very large contributing area may result. Under many plans of development, maximum withdrawal rates are never reached and much smaller contributing areas result.

(3) Well-field design: The number of wells, their spacing, and their locations relative to aquifer boundaries affect the size and shape of a contributing area. This information if available, results in model simulations that represent existing or future conditions more accurately.

A final item concerns construction details of the model. Data from the hypothetical-aquifer model and the Farmington aquifer model indicate that precise definition of water-table altitudes near the center of pumping is critical for determining the direction of ground-water flow and defining the configuration of the contributing area. For this reason, a relatively small grid size (200 by 200 feet) and a relatively large map scale ( 1 inch equals 667 feet) were used for the model of the Farmington aquifer. When investigating other areas, the grid dimensions should be selected on the basis of (1) the size of the area to be modeled, (2) the scale of the map, and (3) the degree of accuracy required for the final product. For areas similar in size to the Farmington aquifer, a grid-spacing of 200 feet or less will likely be needed in the vicinity of the pumping center to define water-table altitudes adequately. Areas some distance from the pumping center can tolerate a larger grid spacing. Other stratified-drift aquifers may have less data, however, the relatively small 200-foot grid spacing used for the Farmington model is still needed if water-table altitudes and directions of flow in the vicinity of a pumping center are to be defined adequately.

The two-dimensional, finite-difference ground-water flow model (Trescott and others, 1976) used in this study is one of several groundwater flow models that are presently available. Selection of a different flow model for similar investigations of other aquifers in the State would require that the model be: 
(1) Capable of defining relatively small changes in water-table altitudes, especiaily near the pumping wells.

(2) Capable of accommodating a variety of boundary conditions, and of simulating ground-water evapotranspiration losses, and able to permit areal changes in major hydrologic characteristics.

(3) Completely documented, with the documentation either published separately or included as part of the report of the aquifer under investigation.

(4) Written in a programming language with which the chief investigator is familiar. This will facilitate any modifications to the computer code that may be needed during the course of the study.

\section{SUMMARY AND CONCLUSIONS}

Two-dimensional, digital flow models of a hypothetical stratified-drift aquifer were constructed, and a series of simulations were run in order to investigate (1) the use of a modeling technique to estimate the size and shape of the area contributing ground water to a pumping center and (2) the effect of changes in natural recharge rates and average aquifer hydraulic conductivity on the size and shape of these areas.

Values of recharge and aquifer hydraulic conductivity were selected to represent average, least-favorable, and most-favorable hydrologic conditions, and simulations were run under steady-state and 180-day transient conditions. Areas contributing ground water to pumping centers were estimated from water levels provided by the mode1. For a single well withdrawing $1.2 \mathrm{Mgal} / \mathrm{d}$, the size of the contributing area ranged from about $0.15 \mathrm{mi}^{2}$ for the most-favorable combination of hydrologic conditions and 180 days of pumping to about $0.75 \mathrm{mi}^{2}$ for least-favorable hydrologic conditions and steady-state conditions.

Another two-dimensional, digital flow model, representing the Farmington aquifer, was constructed and calibrated. This model assumed a withdrawal rate of about $2.85 \mathrm{Mgal} / \mathrm{d}$ (from three hypothetical we $11 \mathrm{~s}$ ), and used recharge rates and aquifer hydraulic conductivities selected to represent average, least-favorable, and most-favorable hydrologic conditions. The sizes of the contributing areas, as predicted by the mode1, were 1.37 $\mathrm{mi}^{2}$ for average conditions, $1.94 \mathrm{mi}^{2}$ for least-favorable conditions, and $0.89 \mathrm{mi}^{2}$ for most-favorable conditions. 
In many areas of Connecticut underlain by large stratified-drift aquifers, the techniques described in this report can be applied and used to estimate the configuration of the recharge areas that develop around pumping centers. Use of a digital flow model to estimate the configurations of areas that contribute flow to pumping centers in other aquifers in Connecticut should consider both the availability of hydrogeologic data in an area and the acceptable level of accuracy. Data needed to construct and calibrate a representative model should be readily available, otherwise data-collection activities must precede any serious modeling efforts. In addition, information relative to existing and planned development of the aquifer are needed. If available, the locations of proposed centers of pumping, anticipated withdrawal rates, and general information on we 11 locations and spacing would enable the model, when constructed and calibrated, to predict the sizes and shapes of the recharge areas that would result from actual ground-water withdrawals.

Construction details relative to the model used for a particular investigation would be governed by the type of model selected, the size of the area under investigation, and the level of accuracy needed. Any model used should have the ability to define relatively small changes in watertable altitudes, especially in the vicinity of a pumping center, inasmuch as accurate delineation of the configuration of contributing areas is based on this information. 
Aquifer: A geologic formation, group of formations, or part of a formation that contains saturated permeable materials and yields usable amounts of water to wells and springs.

Arkose: A sandstone containing 25 percent or more feldspar.

Bedrock: Solid rock, sometimes called "ledge", that forms the earth's crust. It may be exposed at the surface but more commonly is buried beneath a few inches to more than three hundred feet of unconsolidated deposits.

Cubic feet per second $\left(\mathrm{ft}^{3} / \mathrm{s}\right)$ : A term expressing the rate of discharge of surface water. One cubic foot per second is equal to the discharge of a stream 1 foot wide and 1 foot deep flowing at an average velocity of 1 foot per second.

Diabase: An intrusive igneous rock of basaltic composition.

Drainage basin: The area or tract of land that gathers water and contributes it ultimately to a particular stream channel, lake, or other body of water.

Drawdown: The lowering of the water table or potentiometric surface of an aquifer caused by the withdrawal of water by pumping; it is equal to the difference between the static water level and the pumping water level.

Feldspar: A common, rock-forming silicate mineral.

Gravel: Unconsolidated rock debris composed principally of rounded particles larger than 2 millimeters in diameter.

Ground water: Water in the saturated zone.

Ground-water evapotranspiration (GWET): Ground water discharged to the atmosphere in the gaseous state either by direct evaporation or by the transpiration of plants.

Ground-water outflow: The sum of ground-water runoff and underflow; it includes all natural ground-water discharge from a drainage area exclusive of ground-water evapotranspiration.

Ground-water runoff: Ground water that has discharged into stream channels by seepage from saturated earth materials.

Head, static: The height of the surface of a water column above a standard datum that can be supported by the static pressure at a given point.

Hydraulic boundary: A physical feature that limits or defines the areal extent of an aquifer. No-flow boundaries, constant-flux boundaries and constant-head boundaries are examples. 
Hydraulic conductivity $(K)$ : A measure of the ability of a porous medium to transmit a fluid. Material has a hydraulic conductivity of unit length per unit time (1 foot per day) if it will transmit in unit time (1 day) a unit volume of water ( 1 cubic foot) at the prevailing kinematic viscosity through a cross section of unit area (1 square foot), measured at right angles to the direction of flow, under a unit hydraulic gradient ( 1 foot per foot).

Hydraulic gradient: The change in static head per unit of distance in a given direction. If not specified, the direction is generally understood to be that of the maximum rate of decrease in head.

Inches of water: A volume of water expressed as the depth, in inches, to which it would accumulate if spread evenly over a particular area.

Long-term well yield: The yield of a well or group of wells that can reasonably be expected under conditions of continuous pumping, over extended time periods.

Natura 1 recharge: Water that, under natural conditions, infiltrates to the saturated zone. In Connecticut, precipitation is the principal source of natural recharge to aquifers.

Partial penetration: A condition in which a water well is not open to the entire saturated thickness of the aquifer.

Precipitation: The discharge of water from the atmosphere, in either a liquid or solid state (principally rain and snow).

Runoff: The part of precipitation that appears in streams. It is the same as streamflow corrected for artificial diversions, storage, or other human activities.

Saturated thickness: Thickness of an aquifer below the water table.

Specific yield: The ratio of the volume of water which a saturated rock or soil will yield, by gravity drainage, to its own volume.

Storage coefficient: The volume of water an aquifer releases from or takes into storage per unit surface area of the aquifer per unit change in head. In an unconfined aquifer, the storage coefficient is approximately equal to the specific yield.

Stratified drift: A sorted sediment deposited in layers, by or in glacial meltwaters; includes gravel, sand, silt, and clay.

Stream-aquifer system: A natural flow system consisting of a stream and a hydraulically connected aquifer.

Ti11: Unsorted, unstratified sediments deposited directly by glacial ice and composed of a mixture of boulders, gravel, sand, silt, and clay. 
Unconfined aquifer (water-table aquifer): An aquifer in which the upper surface of the saturated zone (the water table) is at atmospheric pressure and is free to rise and fall.

Unconsolidated: Loose, not firmly cemented or interlocked--for example, sand as compared to sandstone.

Water table: The upper surface of the saturated zone of an unconfined aquifer. 


\section{SELECTED REFERENCES}

Bredehoeft, J. D. and Pinder, G. F., 1970, Digital analysis of areal flow in multi-aquifer ground-water systems: A quasi three-dimensional model: Water Resources Research, v. 6, no. 3, p. 883-888.

Colton, R. B., 1970, Surficial geology of the Collinsville quadrangle, Connecticut: U.S. Geological Survey Open-file map, scale 1:24,000.

Connecticut Areawide Waste Treatment Management Planning Board, 1979, A guide to ground water and aquifer protection - final report: The 208 Central office, Middletown, Connecticut, $47 \mathrm{p}$.

Haeni, F. P., 1978, Computer modeling of the ground-water availability in the Pootatuck River valley, Newtown, Connecticut, with a section on quality of water by El inor H. Handman: U.S. Geological Survey WaterResources Investigations Report 78-77, $64 \mathrm{p}$.

Handman, E. H., Haeni, F. P., and Thomas, M. P., 1986, Water-resources inventory of Connecticut, part 9, Farmington River basin: Connecticut Water Resources Bullet in 29, 91 p.

Hopkins, H. T. and Handman, E. H., 1975, Hydrogeologic data for the Farmington River basin, Connecticut: Connecticut Water Resources Bullet in 28, $49 \mathrm{p}$.

Lohman, S. W., 1972, Ground-water hydraulics: U.S. Geological Survey Professional Paper 708, $70 \mathrm{p}$.

Mazzaferro, D. L., 1973, Hydrogeologic data for the Quinnipiac River basin, Connecticut: Connecticut Water Resources Bullet in 26, 54 p.

1980, Ground-water availability and water quality in Farmington, Connecticut: U.S. Geological Survey Water-Resources Investigations Report 80-751, 57 p.

1986, Ground-water availability and water quality at Woodbury and Southbury, Connecticut: U.S. Geological Survey Water-Resources Investigations Report 84-4221, $105 \mathrm{p}$.

Mazzaferro, D. L., Handman, E. H., and Thomas, M. P., 1979, Water-resources inventory of Connecticut, part 8, Quinnipiac River basin: Connecticut Water Resources Bullet in 27, 88 p.

Meinzer, 0. E. and Stearns, N. D., 1929, A study of ground water in the Pomperaug River basin, Connecticut with special reference to intake and discharge: U.S. Geological Survey Water-Supply Paper 597-B, p. 73-146.

Melvin, R. L., 1976, Hydrogeology of stratified drift in Farmington, Connecticut: U.S. Geological Survey Open-File Report 76-248, 28 p.

Pinder, G. F. and Bredehoeft, J. D., 1968, Application of a digital computer for aquifer evaluation: Water Resources Research, v. 4, no. 5, p. 10691093. 
Randa11, A. D., 1964a, Geology and ground water in the Farmington-Granby area, Connecticut: U.S. Geological Survey Water-Supply Paper 1661, 129 p.

1964b, Records and logs of selected wells and test borings, records of springs, and chemical analyses of water in the Farmington-Granby area, Connecticut: Connecticut Water Resources Bullet in 3, $25 \mathrm{p}$.

Remson, Irwin, Hornberger, G. M., and Molz, F. J., 1971, Numerical methods in subsurface hydrology: New York, Wiley-Interscience, $389 \mathrm{p}$.

Ryder, R. B., Weiss, L. A., and Thomas, M. P., 1981, Water-resources inventory of Connecticut, part 7, Upper Connecticut River basin, Connecticut Water Resources Bullet in 24, 78 p.

Schnabel, R. W., 1962, Surficial geology of the Avon quadrangle, Connecticut: U.S. Geological Survey Geologic Quadrangle Map GQ-147, scale $1: 24,000$.

Simpson, H. E., 1959, Surficial geology of the New Britain quadrangle, Connecticut: U.S. Geological Survey Geologic Quadrangle Map GQ-119, scale $1: 24,000$.

1961, Surficial geology of the Bristol quadrangle, Connecticut: U.S. Geological Survey Geologic Quadrangle Map GQ-145, scale 1:24,000.

Theis, C. V., 1935, The relation between the lowering of the piezometric surface and the rate and duration of discharge of a well using groundwater storage: American Geophysical Union Transactions, part 2, p. 519524.

Trescott, P. C., Pinder, G. F., and Larson, S. P., 1976, Finite-difference model for aquifer simulation in two dimensions with results of numerical experiments: U.S. Geological Survey Techniques of Water-Resources Investigations, Book 7, Chapter $\mathrm{C} 1,116 \mathrm{p}$.

U.S. Geological Survey, 1966-83 (issued annually), Water Resources Data for Connecticut: U.S. Geological Survey Water-Data Reports. 


\section{APPENDIX A}

Listing of input for the initial hypothetical-aquifer model

Line No.

1: HYPOTHETICAL DRAWDOWN MODEL FOR AN EXTENSIVE STRATIFIED DRIFT AQUIFER IN CONN.

2: $500 \times 500-F T$ SPACING. REFERENCE RUN.

3: WATE LEAK EVAP RECH SIP CHEC

4: $\quad 41 \quad 42 \quad 000$

5: CONT $\quad 1 \quad 1625$

6:

7:

8:

9:

10:

11:

12:

13:

14:

15:

16:

17:

18:

19:

20:

21:

22:

23:

24:

25:

26:

27:

28:

29:

30:

31:

32:

33:

34:

35:

36:

37:

38:

39:

40:

41:

42:

43:

44:

45:

46:

47:

48:

49:

50: NUME HEAD

$\begin{array}{lrrr}1 & 1 & \text { FEET } & \\ 0 & 6.6 \mathrm{E}-08 & & 5\end{array}$

(BLANK LINE)

(BLANK LINE)

(BLANK LINE)

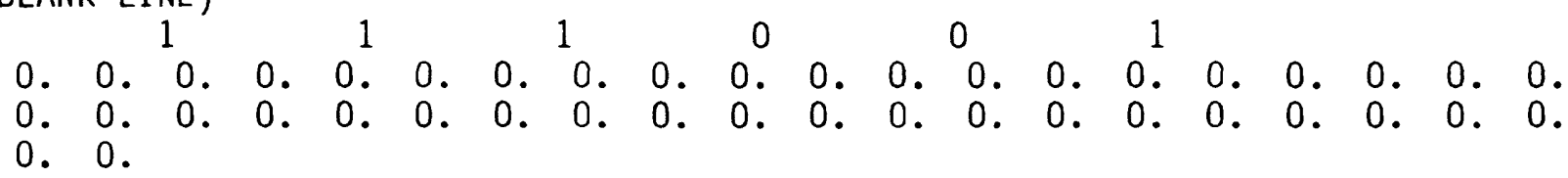

0.203 .203 .203 .203 .202 .202 .202 .202 .201 .201 .201 .201 .200 .200 .200 .200 .199 .199 .199 . 199.198 .198 .198 .198 .197 .197 .197 .197 .196 .196 .196 .195 .195 .195 .195 .195 .194 .194 .194 . 194. 0.

0.202 .202 .201 .201 .201 .201 .201 .200 .200 .200 .200 .199 .199 .199 .199 .198 .198 .198 .198 . 197.197 .197 .196 .196 .196 .196 .195 .195 .195 .195 .194 .194 .194 .194 .193 .193 .193 .193 .192$. 192. 0.

0.201 .200 .200 .200 .200 .199 .199 .199 .199 .198 .198 .198 .198 .197 .197 .197 .197 .196 .196$. 196.196.195.195.195.194.194.194.194.193.193.193.193.192.192.192.192.191.191.191. 191. 0.

0.199 .199 .199 .198 .198 .198 .198 .197 .197 .197 .197 .196 .196 .196 .196 .195 .195 .195 .194$. 194.194 .194 .193 .193 .193 .193 .192 .192 .192 .192 .191 .191 .191 .190 .190 .190 .190 .189 .189 . 189. 0.

0.197 .197 .197 .197 .196 .196 .196 .196 .195 .195 .195 .195 .194 .194 .194 .194 .193 .193 .193$. 192.192 .192 .192 .191 .191 .191 .191 .190 .190 .190 .189 .189 .189 .189 .188 .188 .188 .188 .187 . 187.0 . 0.

0.195 .195 .195 .195 .195 .194 .194 .194 .194 .193 .193 .193 .192 .192 .192 .192 .191 .191 .191$. 191.190 .190 .190 .189 .189 .189 .189 .188 .188 .188 .187 .187 .187 .187 .186 .186 .186 .186 .185 . 185. 0 .

0.194 .193 .193 .193 .193 .192 .192 .192 .192 .191 .191 .191 .190 .190 .190 .190 .189 .189 .189 . 188.188 .188 .188 .187 .187 .187 .186 .186 .186 .186 .185 .185 .185 .185 .184 .184 .184 .183 .183 . 183. 0 .

0.191 .191 .191 .191 .190 .190 .190 .190 .189 .189 .189 .189 .188 .188 .188 .187 .187 .187 .186 . 186.186 .186 .185 .185 .185 .184 .184 .184 .184 .183 .183 .183 .182 .182 .182 .182 .181 .181 .181 . 181.0 . 0.

0.189 .189 .189 .188 .188 .188 .188 .187 .187 .187 .186 .186 .186 .186 .185 .185 .185 .184 .184 . 184.183 .183 .183 .183 .182 .182 .182 .181 .181 .181 .180 .180 .180 .180 .179 .179 .179 .179 .178 . 178. 0.

0.187 .186 .186 .186 .186 .185 .185 .185 .184 .184 .184 .184 .183 .183 .183 .182 .182 .182 .181$. 181.181 .180 .180 .180 .180 .179 .179 .179 .178 .178 .178 .177 .177 .177 .177 .176 .176 .176 .175 . 175. 0.

0.184 .184 .183 .183 .183 .183 .182 .182 .182 .181 .181 .181 .180 .180 .180 .180 .179 .179 .179$. 178.178 .178 .177 .177 .177 .176 .176 .176 .175 .175 .175 .174 .174 .174 .174 .173 .173 .173 .172 . 172. 0 .

0.181 .181 .181 .180 .180 .180 .179 .179 .179 .178 .178 .178 .178 .177 .177 .177 .176 .176 .176 . 175.175 .175 .174 .174 .174 .173 .173 .173 .172 .172 .172 .171 .171 .171 .170 .170 .170 .170 .169 . 169. 0 . 
Listing of input for the initial hypothetical-aquifer model

\section{Line No.}

51: $\quad 0.178 .178 .177 .177 .177 .177 .176 .176 .176 .175 .175 .175 .174 .174 .174 .173 .173 .173 .172$.

52:

53:

54:

55:

56:

57:

58:

59:

60:

61:

62:

63:

64:

65:

66:

67:

68:

69:

70:

71:

72:

73:

74:

75:

76:

77:

78:

79:

80:

81:

82:

83:

84:

85:

86:

87:

88:

89:

90:

91:

92:

93:

94:

95:

96:

97:

98:

99: 172.172 .171 .171 .171 .170 .170 .170 .169 .169 .169 .168 .168 .168 .167 .167 .167 .166 .166 .166 . 165. 0 .

0.175 .174 .174 .174 .174 .173 .173 .173 .172 .172 .172 .171 .171 .171 .170 .170 .169 .169 .169$. 168.168 .168 .167 .167 .167 .166 .166 .166 .165 .165 .165 .164 .164 .163 .163 .163 .163 .162 .162 . 162. 0 .

0.171 .171 .171 .170 .170 .170 .169 .169 .169 .168 .168 .168 .167 .167 .166 .166 .166 .165 .165$. 165.164 .164 .163 .163 .163 .162 .162 .162 .161 .161 .161 .160 .160 .159 .159 .159 .158 .158 .158 . 157.0 .

0.167 .167 .167 .167 .166 .166 .165 .165 .165 .164 .164 .164 .163 .163 .162 .162 .162 .161 .161 . 160.160 .160 .159 .159 .158 .158 .158 .157 .157 .157 .156 .156 .155 .155 .155 .154 .154 .154 .153 . 153. 0.

0.163 .163 .163 .162 .162 .162 .161 .161 .160 .160 .160 .159 .159 .158 .158 .158 .157 .157 .156 . 156.156 .155 .155 .154 .154 .154 .153 .153 .152 .152 .151 .151 .151 .150 .150 .150 .149 .149 .148 . 148. 0 .

0.159 .159 .158 .158 .158 .157 .157 .156 .156 .155 .155 .155 .154 .154 .153 .153 .152 .152 .152 . 151.151 .150 .150 .149 .149 .149 .148 .148 .147 .147 .146 .146 .146 .145 .145 .144 .144 .143 .143 . 143. 0 .

0.155 .154 .154 .153 .153 .152 .152 .151 .151 .151 .150 .150 .149 .149 .148 .148 .147 .147 .146$. 146.146 .145 .145 .144 .144 .143 .143 .142 .142 .141 .141 .140 .140 .139 .139 .139 .138 .138 .137 . 137.0 .

0.150 .149 .149 .148 .148 .147 .147 .146 .146 .145 .145 .144 .144 .143 .143 .142 .142 .141 .141 . 140.140 .139 .139 .138 .138 .137 .137 .136 .136 .135 .135 .134 .134 .133 .133 .132 .132 .131 .131 . 130. 0 .

0.155 .154 .154 .153 .153 .152 .152 .152 .151 .151 .150 .150 .149 .149 .148 .148 .147 .147 .146$. 146.146 .145 .145 .144 .144 .143 .143 .142 .142 .141 .141 .140 .140 .139 .139 .139 .138 .138 .137 . 137. 0 .

0.159 .159 .158 .158 .158 .157 .157 .156 .156 .155 .155 .155 .154 .154 .153 .153 .152 .152 .152 . 151.151 .150 .150 .149 .149 .149 .148 .148 .147 .147 .146 .146 .146 .145 .145 .144 .144 .143 .143 . 143. 0 .

0.163 .163 .163 .162 .162 .162 .161 .161 .160 .160 .160 .159 .159 .158 .158 .158 .157 .157 .156 . 156.156 .155 .155 .154 .154 .153 .153 .153 .152 .152 .151 .151 .151 .150 .150 .149 .149 .149 .148 . 148. 0 .

0.167 .167 .167 .167 .166 .166 .165 .165 .165 .164 .164 .164 .163 .163 .162 .162 .162 .161 .161 . 160.160 .160 .159 .159 .158 .158 .158 .157 .157 .157 .156 .156 .155 .155 .155 .154 .154 .154 .153 . 153. 0 .

0.171 .171 .171 .170 .170 .170 .169 .169 .169 .168 .168 .168 .167 .167 .166 .166 .166 .165 .165$. 165.164 .164 .163 .163 .163 .162 .162 .162 .161 .161 .161 .160 .160 .159 .159 .159 .158 .158 .158 . 157. 0 .

0.175 .174 .174 .174 .174 .173 .173 .173 .172 .172 .172 .171 .171 .171 .170 .170 .169 .169 .169 . 168.168 .168 .167 .167 .167 .166 .166 .166 .165 .165 .165 .164 .164 .164 .163 .163 .163 .162 .162 . 162. 0 .

0.178 .178 .177 .177 .177 .177 .176 .176 .176 .175 .175 .175 .174 .174 .174 .173 .173 .173 .172 . 172.172 .171 .171 .171 .170 .170 .170 .169 .169 .169 .168 .168 .168 .167 .167 .167 .166 .166 .166 . 165. 0.

0.181 .181 .180 .180 .180 .180 .179 .179 .179 .178 .178 .178 .177 .177 .177 .177 .176 .176 .176 . 175.175 .175 .174 .174 .174 .173 .173 .173 .172 .172 .172 .171 .171 .171 .170 .170 .170 .170 .169 . 169. 0 .

0.184 .184 .183 .183 .183 .183 .182 .182 .182 .181 .181 .181 .180 .180 .180 .180 .179 .179 .179 . 100:

178.178 .178 .177 .177 .177 .176 .176 .176 .175 .175 .175 .175 .174 .174 .174 .173 .173 .173 .172 . 
Listing of input for the initial hypothetical-aquifer model

Line No.

101: 172.0 .

102: $\quad 0.187 .186 .186 .186 .186 .185 .185 .185 .184 .184 .184 .184 .183 .183 .183 .182 .182 .182 .181$.

103:

104:

105:

106:

107:

108:

109:

110:

111:

112:

113:

114:

115:

116:

117:

118:

119:

120:

121:

122:

123:

124:

125:

126:

127:

128:

129:

130:

131:

132:

133:

134:

135:

136:

137:

138:

139:

140:

141:

142:

143:

144:

145:

146:

147:

148:

149:

181.181 .180 .180 .180 .180 .179 .179 .179 .178 .178 .178 .177 .177 .177 .177 .176 .176 .176 .176 . 175. 0 .

$0.189 .189 .188 \cdot 188 \cdot 188 \cdot 188 \cdot 187.187 .187 \cdot 187.186 \cdot 186 \cdot 186 \cdot 186.185 .185 .185 .184 .184$. 184.183 .183 .183 .183 .182 .182 .182 .181 .181 .181 .180 .180 .180 .180 .179 .179 .179 .179 .178 . 178. 0 .

$0.191 .191 .191 .191 .190 \cdot 190.190 \cdot 190.189 .189 .189 .188 .188 .188 \cdot 188 \cdot 187.187 .187 .186$. 186.186 .186 .185 .185 .185 .184 .184 .184 .184 .183 .183 .183 .182 .182 .182 .182 .181 .181 .181 . 181. 0 .

0.193 .193 .193 .193 .192 .192 .192 .192 .191 .191 .191 .191 .190 .190 .190 .190 .189 .189 .189 . 188.188 .188 .188 .187 .187 .187 .186 .186 .186 .186 .185 .185 .185 .185 .184 .184 .184 .184 .183 . 183. 0 .

0.195 .195 .195 .195 .194 .194 .194 .194 .193 .193 .193 .193 .192 .192 .192 .192 .191 .191 .191 . 191.190 .190 .190 .189 .189 .189 .189 .188 .188 .188 .188 .187 .187 .187 .186 .186 .186 .186 .185 . 185. 0.

0.197 .197.197.197.196.196.196.196.195.195.195.195.194.194.194.194.193.193.193. 192.192 .192 .192 .191 .191 .191 .191 .190 .190 .190 .189 .189 .189 .189 .188 .188 .188 .188 .187 . 187. 0 .

0.199.199.198.198.198.198.198.197.197.197.197.196.196.196.196.195.195.195.194. 194.194.194.193.193.193.193.192.192.192.192.191.191.191.191.190.190.190.190.189. 189. 0 .

0.200 .200 .200 .200 .200 .199 .199 .199 .199 .198 .198 .198 .198 .197 .197 .197 .197 .196 .196 . 196.196.195.195.195.195.194.194.194.193.193.193.193.192.192.192.192.191.191.191. 191. 0 .

0.202.202.201.201.201.201.201.200.200.200.200.199.199.199.199.198.198.198.198. 197.197.197.196.196.196.196.195.195.195.195.194.194.194.194.193.193.193.193.193. 192. 0.

0.203.203.203.202.202.202.202.202.201.201.201.201.200.200.200.200.199.199.199. 199.198.198.198.198.197.197.197.197.196.196.196.196.195.195.195.195.194.194.194. 194. 0 .

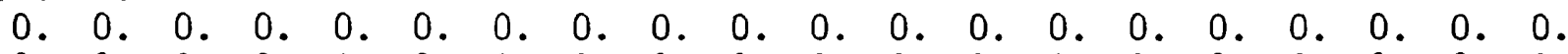
$\begin{array}{llllllllllllllllllll}0 . & 0 . & 0 . & 0 . & 0 . & 0 . & 0 . & 0 . & 0 . & 0 . & 0 . & 0 . & 0 . & 0 . & 0 . & 0 . & 0 . & 0 . & 0 . & 0 .\end{array}$ 0.0 .0 (BLANK LINE)

$\begin{array}{rllll}8.68 E-04 & 0 & 1 & 0 & 0 \\ 20 & 0 & 1 & 0 & 0 \\ 0.0 & 0 & 1 & 0 & 0 \\ 1.62 E-05 & 0 & 1 & 0 & 0 \\ 1 & 1 & 1 & 0 & 0\end{array}$

(BLANK LINE)

(BLANK LINE)

(BLANK LINE)

(BLANK LINE)

(BLANK LINE)

(BLANK LINE)

(BLANK LINE)

(BLANK LINE)

150: (BLANK LINE) 


\section{Line No.}

$\begin{array}{ll}151: & \text { (BLANK LINE) } \\ 152: & \text { (BLANK LINE) } \\ 153: & \text { (BLANK LINE) } \\ 154: & \text { (BLANK LINE) } \\ 155: & \text { (BLANK LINE) } \\ 156: & \text { (BLANK LINE) } \\ 157: & \text { (BLANK LINE) } \\ 158: & \text { (BLANK LINE) } \\ 159: & \text { (BLANK LINE) } \\ 160: & \text { (BLANK LINE) } \\ 161: & \text { (BLANK LINE) } \\ 162: & \text { (BLANK LINE) } \\ 163: & \text { (BLANK LINE) } \\ 164: & \text { (BLANK LINE) } \\ 165: & \text { (BLANK LINE) } \\ 166: & \text { (BLANK LINE) } \\ 167: & \text { (BLANK LINE) } \\ 168: & \text { (BLANK LINE) } \\ 169: & \text { (BLANK LINE) } \\ 170: & \text { (BLANK LINE) } \\ 171: & \text { (BLANK LINE) } \\ 172: & \text { (BLANK LINE) } \\ 173: & \text { (BLANK LINE) } \\ 174: & \text { (BLANK LINE) } \\ 175: & \text { (BLANK LINE) } \\ 176: & \text { (BLANK LINE) } \\ 177: & \text { (BLANK LINE) } \\ 178: & \text { (BLANK LINE) } \\ 179: & \text { (BLANK LINE) } \\ 180: & \text { (BLANK LINE) } \\ 181: & \text { (BLANK LINE) } \\ 182: & \text { (BLANK LINE) } \\ 183: & \text { (BLANK LINE) } \\ 184: & \text { (BLANK LINE) } \\ 185: & \text { (BLANK LINE) } \\ 186: & \text { (BLANK LINE) } \\ 187: & \text { (BLANK LINE) } \\ 188: & \text { (BLANK LINE) } \\ 189: & \text { (BLANK LINE) } \\ 190: & \text { (BLANK LINE) } \\ 191: & \text { (BLANK LINE) } \\ 192: & \text { (BLANK LINE) } \\ 193: & \text { (BLANK LINE) } \\ 194: & \text { (BLANK LINE) } \\ 195: & \text { (BLANK LINE) } \\ 196: & \text { (BLANK LINE) } \\ 197: & \text { (BLANK LINE) } \\ 198: & \text { (BLANK LINE) } \\ 199: & \text { (BLANK LINE) } \\ 200: & \text { (BLANK LINE) }\end{array}$




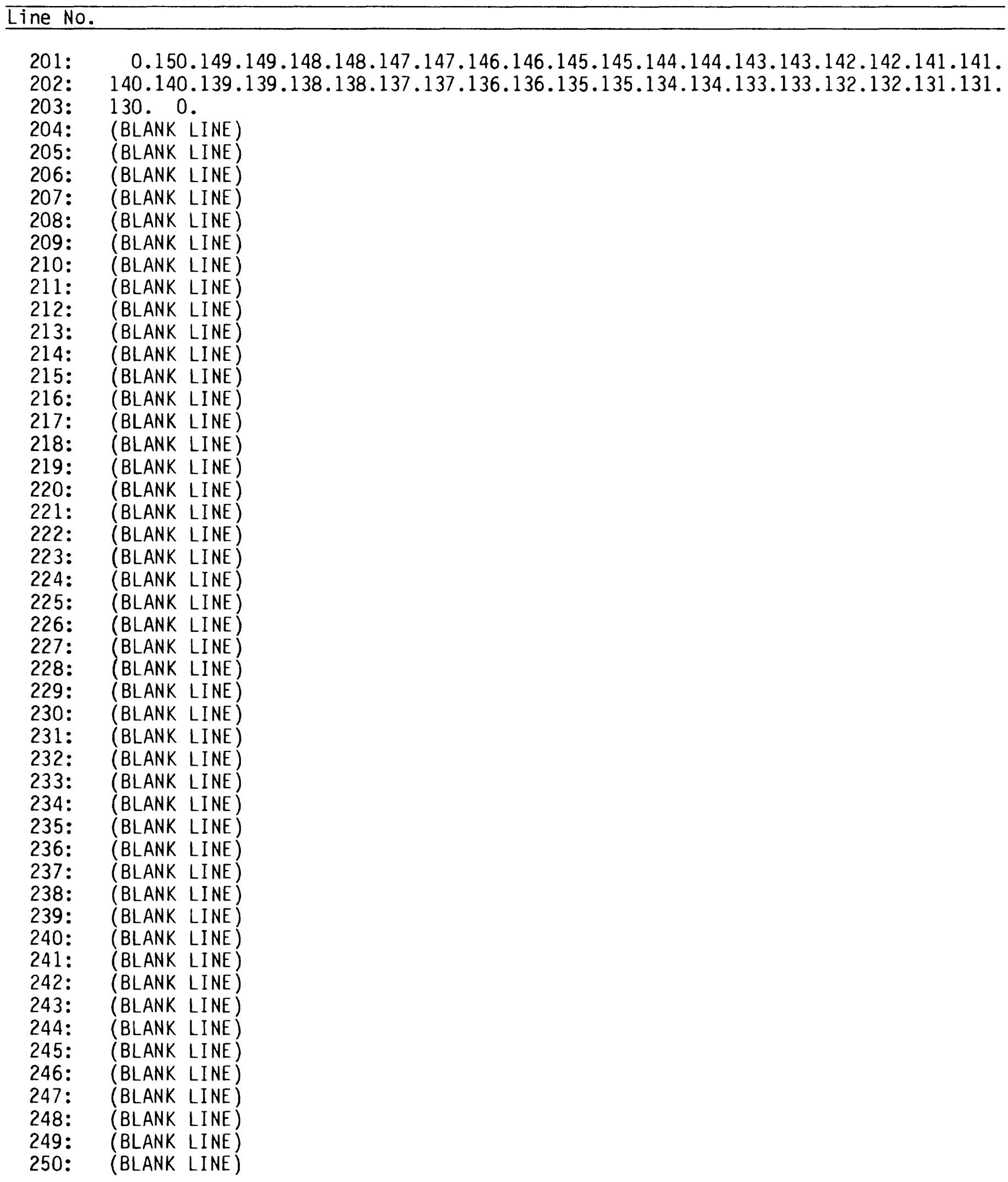


Listing of input for the initial hypothetical-aquifer model

Line No.

251: (BLANK LINE)

252: (BLANK LINE)

253: (BLANK LINE)

254: (BLANK LINE)

255: (BLANK LINE)

256: (BLANK LINE)

257: (BLANK LINE)

258: (BLANK LINE)

259: (BLANK LINE)

260: (BLANK LINE)

261: (BLANK LINE)

262: (BLANK LINE)

263: (BLANK LINE)

264: 2

265: (BLANK LINE)

266: (BLANK LINE)

267: (BLANK LINE)

268: (BLANK LINE)

269: (BLANK LINE)

270: (BLANK LINE)

271: (BLANK LINE)

272: (BLANK LINE)

273: (BLANK LINE)

274: (BLANK LINE)

275: (BLANK LINE)

276: (BLANK LINE)

277: (BLANK LINE)

278: (BLANK LINE)

279: (BLANK LINE)

280: (BLANK LINE)

281: (BLANK LINE)

282: (BLANK LINE)

283: (BLANK LINE)

284: (BLANK LINE)

285: (BLANK LINE)

286: (BLANK LINE)

287: (BLANK LINE)

288: (BLANK LINE)

289: (BLANK LINE)

290: (BLANK LINE)

291: (BLANK LINE)

292: (BLANK LINE)

293: (BLANK LINE)

294: (BLANK LINE)

295: (BLANK LINE)

296: (BLANK LINE)

297: (BLANK LINE)

298: (BLANK LINE)

299: (BLANK LINE)

300: (BLANK LINE) 


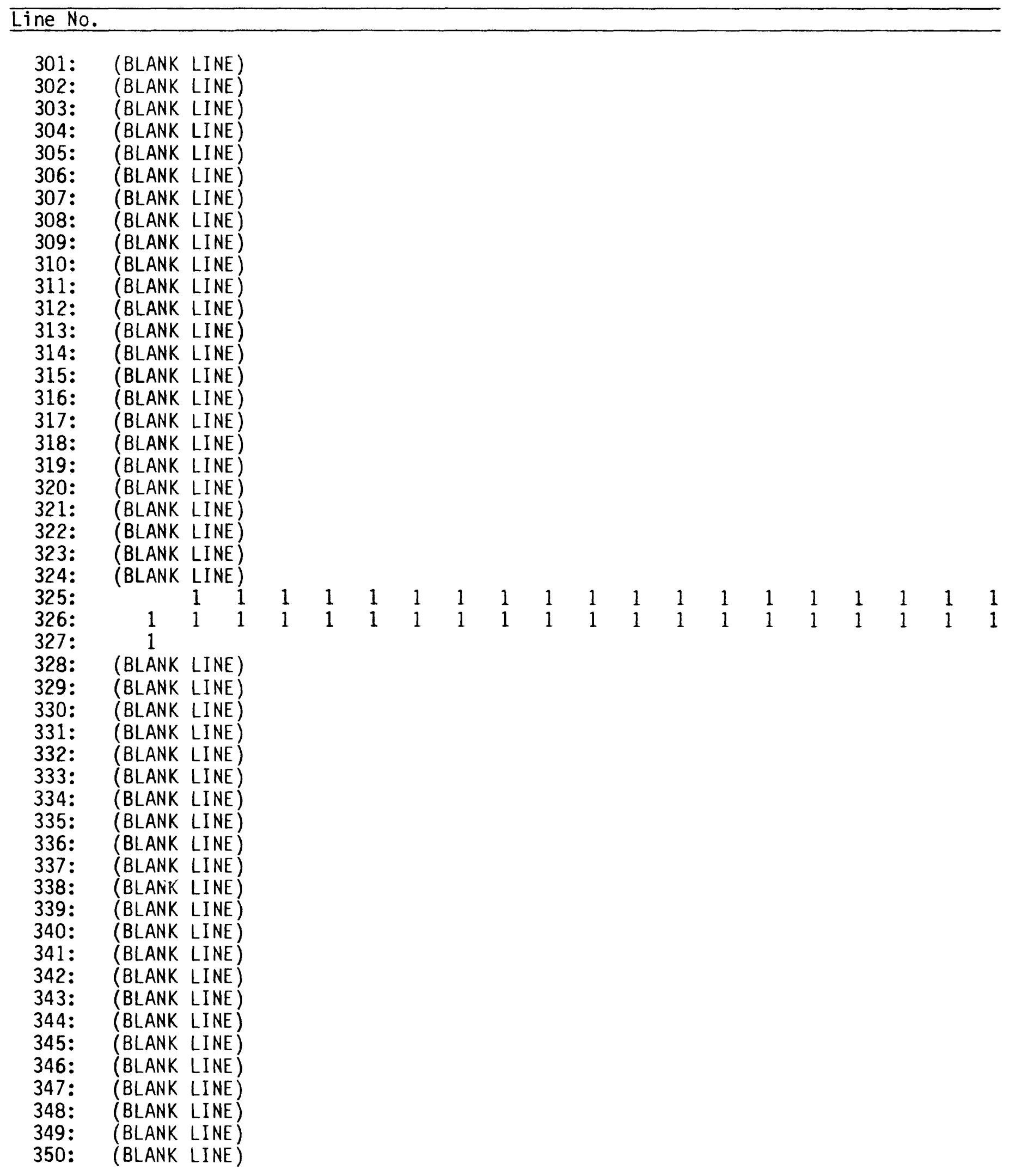




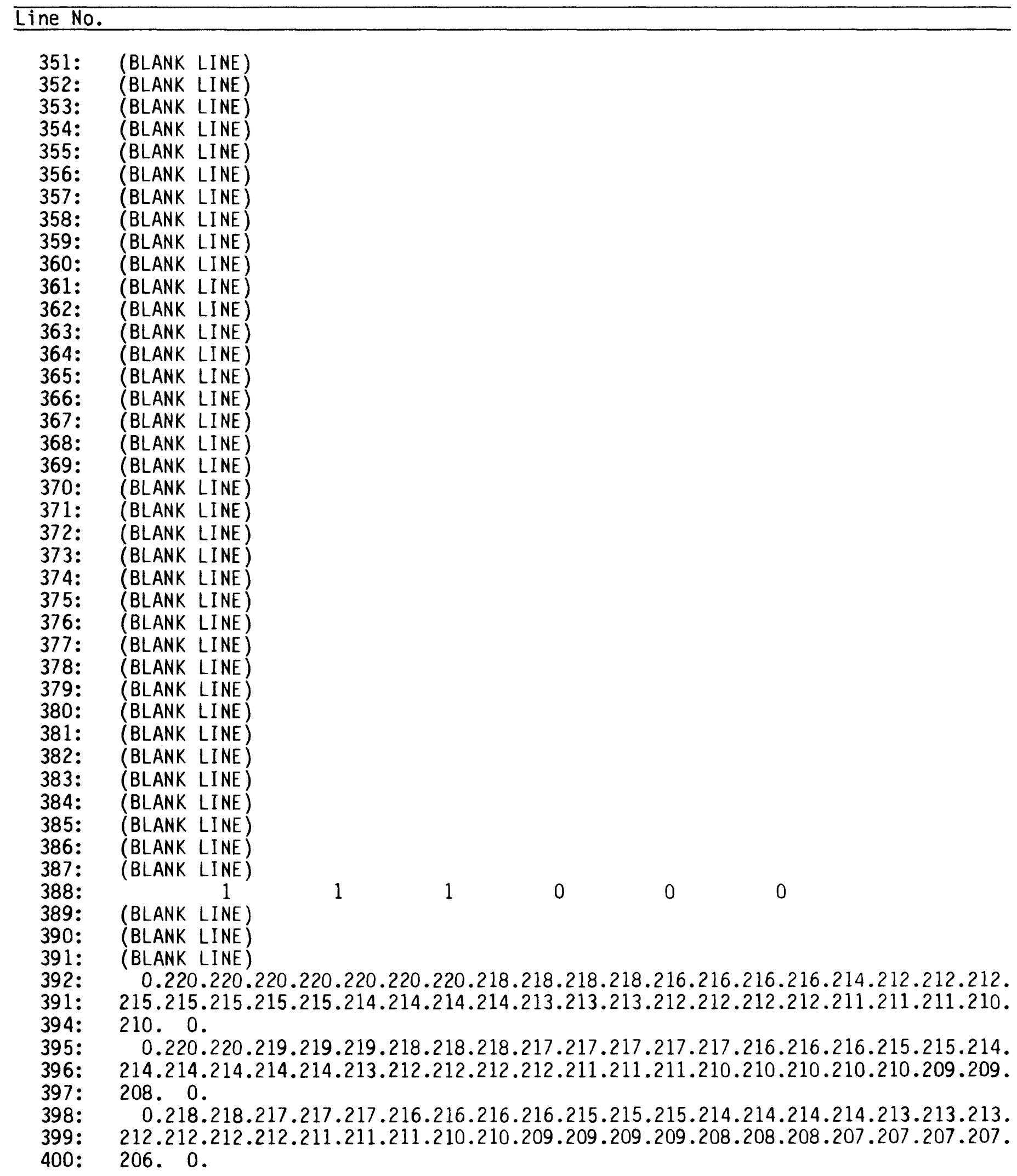


Listing of input for the initial hypothetical-aquifer model

Line No.

401: $\quad \quad \quad 0.216 .216 .216 .215 .215 .215 .214 .214 .214 .213 .213 .213 .212 .212 .212 .212 .211 .211 .211$. 402: $\quad 210.210 .210 .208 .208 .208 .208 .208 .208 .208 .207 .207 .207 .207 .206 .206 .206 .206 .205 .205$.

403:

404:

405:

406:

407:

408:

409:

410:

411:

412:

413:

414:

415:

416:

417:

418:

419:

420:

421:

422:

423:

424:

425:

426:

427:

428:

429:

430:

431:

432:

433:

434:

435:

436:

437:

438:

439:

440:

441:

442:

443:

444:

445:

446:

447:

448:

449:

450:

204. 0.

0.214 .214 .213 .213 .213 .213 .212 .212 .212 .212 .211 .211 .210 .210 .210 .208 .208 .206 .206 . 216.216 .208 .207 .207 .207 .226 .206 .206 .205 .205 .205 .205 .204 .204 .204 .204 .203 .203 .202 . 202. 0 .

0.212 .212 .211 .211 .211 .210 .210 .210 .208 .208 .208 .206 .206 .206 .206 .204 .204 .204 .203 . 206.206 .205 .205 .205 .204 .204 .204 .204 .203 .203 .203 .203 .203 .202 .202 .202 .202 .200 .200 . 200. 0 .

0.210 .210 .210 .208 .208 .208 .208 .208 .207 .207 .207 .206 .206 .206 .206 .205 .205 .205 .204 . 204.203 .203 .203 .202 .202 .202 .202 .201 .201 .201 .200 .200 .199 .199 .199 .198 .198 .198 .197 . 197. 0.

0.207 .207 .207 .206 .206 .206 .205 .205 .204 .204 .204 .204 .204 .203 .203 .202 .202 .202 .201 . 201.201 .200 .200 .200 .199 .199 .199 .198 .198 .198 .197 .197 .197 .196 .196 .196 .196 .196 .195$. 195. 0.

0.204 .204 .204 .203 .203 .203 .202 .202 .202 .202 .201 .201 .200 .200 .199 .199 .199 .198 .198 . 198.198 .197 .197 .197 .197 .166 .196 .196 .195 .195 .195 .195 .194 .193 .193 .193 .193 .192 .192 . 192. 0.

0.202 .201 .201 .201 .200 .200 .200 .199 .199 .199 .198 .198 .198 .197 .197 .197 .196 .196 .196$. 195.195 .195 .194 .194 .194 .193 .193 .193 .192 .192 .192 .191 .191 .191 .190 .190 .190 .189 .189 . 189.0 . 0.

0.199 .198 .198 .198 .197 .197 .196 .196 .196 .196 .195 .195 .194 .194 .194 .194 .193 .193 .192$. 192.192 .191 .191 .191 .190 .190 .190 .189 .189 .189 .188 .188 .188 .187 .187 .187 .186 .186 .186 . 185. 0.

0.195 .195 .195 .194 .194 .194 .193 .193 .193 .192 .192 .192 .191 .191 .190 .190 .190 .189 .189 . 189.188 .188 .188 .187 .187 .187 .186 .186 .186 .185 .185 .184 .184 .184 .184 .183 .183 .182 .182 . 182. 0.

0.192 .192 .191 .191 .190 .190 .190 .189 .189 .189 .188 .188 .188 .187 .187 .187 .186 .186 .186 . 185.185 .184 .184 .184 .183 .183 .183 .182 .182 .182 .181 .181 .180 .180 .179 .179 .179 .179 .178 . 178. 0.

$0.184 .184 .184 .183 .183 .182 .182 .182 .181 .181 .181 .180 .180 .179 .179 .179 .178 \cdot 178.178$. 177.177 .176 .176 .176 .175 .175 .175 .174 .174 .174 .173 .173 .172 .172 .172 .171 .171 .170 .170 . 170. 0 .

0.179 .179 .179 .178 .178 .177 .177 .177 .176 .176 .176 .175 .175 .175 .174 .174 .173 .173 .173$. 172.172 .171 .171 .171 .170 .170 .169 .169 .169 .168 .168 .167 .167 .167 .166 .167 .166 .166 .166 . 164. 0 .

0.174 .174 .173 .173 .173 .172 .172 .171 .171 .171 .170 .170 .169 .169 .169 .168 .168 .167 .167$. 167.166 .166 .166 .165 .165 .164 .164 .163 .163 .163 .162 .162 .161 .161 .161 .160 .160 .159 .159 . 158. 0 .

0.169 .168 .168 .167 .167 .167 .166 .166 .165 .152 .165 .164 .164 .163 .163 .162 .162 .162 .161$. 161.160 .160 .159 .159 .159 .158 .158 .157 .157 .157 .156 .156 .155 .155 .155 .154 .154 .153 .153 . 152. 0 .

0.163 .162 .162 .162 .161 .161 .160 .160 .159 .159 .158 .158 .158 .157 .157 .156 .156 .155 .155$. 154.154 .154 .153 .153 .152 .152 .152 .151 .151 .150 .150 .149 .149 .148 .148 .148 .147 .147 .146 . 146. 0.

0.157 .155 .156 .155 .155 .154 .154 .153 .153 .153 .152 .151 .151 .151 .150 .150 .149 .149 .148$. 148.147 .147 .147 .146 .145 .145 .145 .144 .144 .143 .143 .142 .142 .141 .141 .140 .140 .139 .139 . 138. 0 .

0.150 .150 .149 .148 .148 .147 .147 .146 .146 .145 .145 .144 .143 .143 .142 .142 .141 .141 .141 . 140.140 .139 .139 .138 .138 .137 .137 .136 .136 .135 .135 .134 .134 .133 .133 .132 .132 .131 .131 . 
Listing of input for the initial hypothetical-aquifer model

Line No.

451: $\quad 130.0$.

452:

453:

454:

455:

456:

457:

458:

459:

460:

461:

462:

463:

464:

465:

466:

467:

468:

469:

470:

471:

472:

473:

474:

475:

476:

477:

478:

479:

480:

481:

482:

483:

484:

485:

486:

487:

488:

489:

490:

491:

492:

493:

494:

495:

496:

497:

498:

499:

500:

0.157 .156 .156 .155 .155 .154 .154 .153 .153 .153 .152 .151 .151 .151 .150 .151 .149 .149 .148 . 148.147 .147 .146 .146 .145 .145 .145 .144 .144 .143 .143 .142 .142 .142 .141 .141 .140 .140 .139 . 138. 0.

0.163 .162 .162 .162 .161 .161 .160 .160 .159 .159 .158 .156 .158 .157 .157 .156 .156 .155 .155 . 154.154 .154 .153 .153 .152 .152 .152 .151 .151 .150 .150 .149 .149 .148 .147 .148 .147 .147 .144 . 146. 0.

0.169 .168 .168 .167 .167 .167 .166 .166 .165 .165 .165 .165 .164 .163 .163 .163 .161 .161 .161 . 160.160 .160 .159 .159 .159 .158 .158 .157 .157 .157 .156 .156 .155 .155 .155 .154 .154 .153 .153 . 151. 0 .

0.174 .174 .173 .173 .173 .171 .172 .171 .171 .171 .170 .170 .169 .169 .169 .168 .168 .167 .167$. 167.166 .166 .165 .165 .165 .164 .164 .153 .162 .162 .161 .161 .161 .161 .160 .160 .159 .159 .159$. 158. 0 .

0.179 .179 .179 .178 .178 .178 .177 .177 .176 .176 .176 .175 .175 .175 .174 .174 .174 .173 .173 . 172.172 .171 .171 .171 .170 .170 .169 .169 .169 .168 .168 .167 .167 .167 .166 .166 .165 .165 .165 . 164. 0.

0.184 .184 .184 .183 .183 .182 .182 .181 .181 .181 .181 .180 .180 .179 .179 .179 .178 .178 .178 . 177.177 .176 .176 .176 .175 .175 .175 .174 .174 .174 .173 .173 .172 .172 .172 .171 .171 .170 .170 . 170. 0.

0.192 .192 .192 .191 .190 .190 .190 .189 .189 .189 .188 .188 .188 .187 .187 .187 .186 .186 .186 . 185.185 .184 .184 .184 .183 .183 .183 .183 .182 .182 .181 .181 .180 .180 .180 .179 .179 .179 .179 . 178. 0.

0.195 .195 .195 .194 .194 .194 .193 .193 .193 .192 .192 .192 .191 .191 .190 .190 .190 .189 .189 . 189.188 .188 .188 .187 .187 .187 .186 .186 .186 .185 .185 .185 .184 .184 .184 .183 .183 .183 .182 . 182. 0.

0.199 .198 .198 .198 .197 .197 .197 .196 .196 .196 .195 .195 .195 .194 .194 .194 .194 .193 .193$. 192.192 .192 .191 .191 .190 .190 .190 .189 .189 .189 .188 .188 .188 .188 .188 .187 .186 .186 .186$. 185. 0.

0.202 .201 .201 .201 .200 .200 .199 .199 .199 .199 .198 .198 .198 .197 .197 .197 .196 .196 .196 . 195.195 .195 .194 .194 .194 .194 .194 .193 .192 .192 .192 .191 .191 .191 .190 .190 .189 .189 .189 . 189. 0.

0.204 .204 .204 .204 .203 .203 .202 .202 .202 .202 .201 .201 .201 .200 .200 .200 .199 .199 .199 . 198.198 .198 .187 .197 .197 .196 .196 .196 .195 .195 .195 .194 .194 .194 .193 .193 .193 .192 .192 . 192. 0.

0.207 .207 .206 .206 .206 .206 .206 .206 .205 .205 .204 .204 .204 .203 .203 .203 .202 .202 .202 . 201.201 .200 .200 .200 .199 .199 .198 .198 .198 .198 .197 .197 .197 .197 .196 .196 .196 .195 .195 . 195. 0 .

0.209 .209 .209 .209 .209 .208 .208 .208 .207 .207 .207 .206 .206 .206 .206 .205 .205 .205 .204 . 204.203 .203 .203 .202 .202 .202 .201 .201 .201 .200 .200 .200 .200 .199 .199 .199 .199 .198 .198 . 197. 0.

0.212 .121 .211 .211 .211 .210 .210 .210 .209 .209 .208 .208 .207 .207 .207 .207 .207 .207 .207 . 206.206.205.205.205.204.204.204.204.204.203.203.203.203.202.202.201.201.201.200. 200. 0.

0.214 .214 .214 .214 .213 .213 .213 .213 .212 .212 .212 .211 .211 .210 .210 .210 .210 .210 .208 . 208.208.208.207.207.207.207.206.206.206.205.205.205.204.204.204.204.203.203.203. 202. 0 .

0.216 .216 .216 .215 .215 .215 .214 .214 .214 .214 .213 .213 .213 .212 .212 .212 .211 .211 .211 . 211.210.210.210.209.209.209.208.208.207.207.207.207.207.207.206.206.206.206.205. 204. 0.

0.218 .218 .217 .217 .217 .217 .216 .216 .216 .215 .215 .215 .214 .214 .214 .214 .213 .213 .213 . 
Listing of input for the initial hypothetical-aquifer model

\section{Line No.}

501: $\quad 212.212 .212 .212 .211 .211 .211 .210 .210 .210 .210 .209 .209 .209 .208 .208 .208 .207 .207 .207$. 502: 207.0.

503: $\quad 0.220 .220 .219 .219 .219 .218 .218 .218 .218 .217 .217 .217 .216 .216 .216 .215 .215 .215 .215$. 504: 214.214.214.213.213.213.212.212.212.211.211.211.210.210.210.210.209.209.209.209. 505: 208.0.

506: $\quad 0.221 .221 .221 .221 .220 .220 .220 .219 .219 .219 .219 .218 .218 .218 .217 .217 .217 .216 .216$. 507: $\quad 216.216 .215 .215 .215 .214 .214 .214 .214 .213 .213 .213 .212 .212 .212 .212 .211 .211 .211 .210$. 508: 210.0.

509: (BLANK LINE)

510: (BLANK LINE)

511: (BLANK LINE)

512: $\quad 6.6 \mathrm{E}-08$

513:

514:

515:

516:

517:

518:

519:

520:

521:

$522:$

523:

$524:$

525:

526:

527:

$528:$

529:

$530:$

531 :

532:

533:

534:

535:

536:

537:

538:

539:

540:

541:

542:

543:

544:

545:

546:

547:

548:

549:

550:

500

1

24

2

2

2

2

2

2

2

2
2

2

2

2

2

2

2

2

2

2

2

2

2

2

2
2

2
2

2

2

2

2

2

2

2

2

2
0
0
0

0

20

2

3

4

$5 \quad .235$

$6 \quad .235$

$7 \quad .235$

$8 \quad .235$

$9 \quad .235$

$10 \quad .235$

$11 \quad .235$

$12 \quad .235$

$13 \quad .235$

$14 \quad .235$

$15 \quad .235$

$16 \quad .235$

$17 \quad .235$

$18 \quad .235$

$19 \quad .235$

$20 \quad .235$

$21 \quad .235$

$22 \quad .235$

$23 \quad .235$

$24 \quad .235$

$25 \quad .235$

$26 \quad .235$

$27 \quad .235$

$28 \quad .235$

$29 \quad .235$

$30 \quad .235$

$31 \quad .235$

$32 \quad .235$

$33 \quad .235$

$34 \quad .235$

$35 \quad .235$

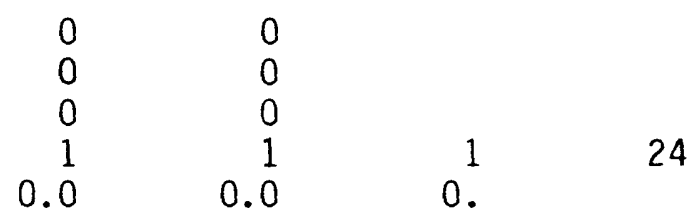

24 .65 
Listing of input for the initial hypothetical-aquifer model

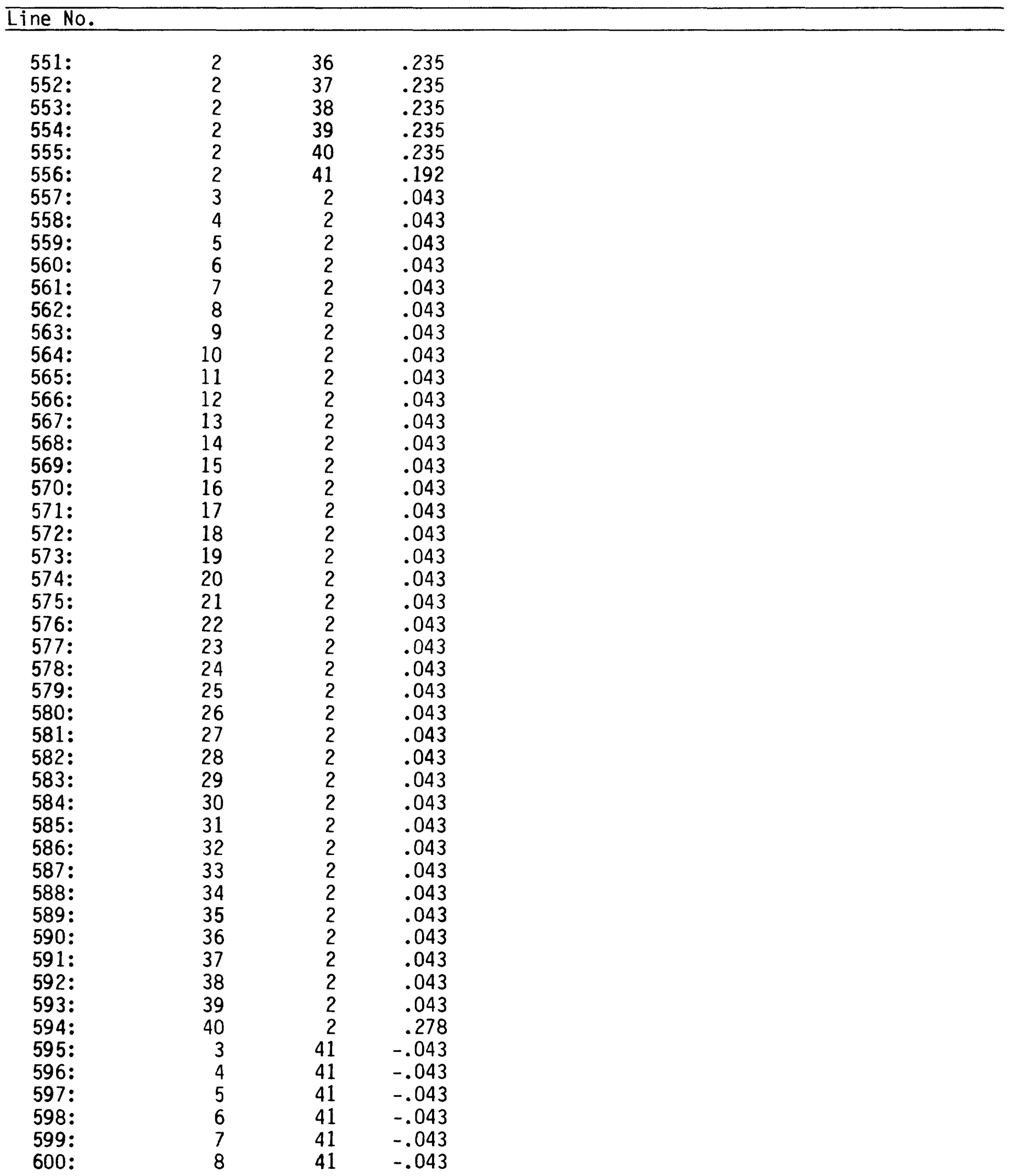


Listing of input for the initial hypothetical-aquifer model

\begin{tabular}{|c|c|c|c|}
\hline ine No & & & \\
\hline 601: & 9 & 41 & -043 \\
\hline $602:$ & 10 & 41 & -.043 \\
\hline 603: & 11 & 41 & -.043 \\
\hline 604: & 12 & 41 & -.043 \\
\hline 605: & 13 & 41 & -.043 \\
\hline 606: & 14 & 41 & -.043 \\
\hline 607: & 15 & 41 & -.043 \\
\hline 608: & 16 & 41 & -.043 \\
\hline 609: & 17 & 41 & -.043 \\
\hline 610: & 18 & 41 & -.043 \\
\hline 611: & 19 & 41 & -.043 \\
\hline 612: & 20 & 41 & -.043 \\
\hline 613: & 21 & 41 & -.043 \\
\hline 614: & 22 & 41 & -.043 \\
\hline 615: & 23 & 41 & -.043 \\
\hline 616: & 24 & 41 & -.043 \\
\hline 617: & 25 & 41 & -.043 \\
\hline 618: & 26 & 41 & -.043 \\
\hline 619: & 27 & 41 & -.043 \\
\hline 620: & 28 & 41 & -.043 \\
\hline 621: & 29 & 41 & -.043 \\
\hline 622: & 30 & 41 & -.043 \\
\hline 623: & 31 & 41 & -.043 \\
\hline 624: & 32 & 41 & -.043 \\
\hline 625: & 33 & 41 & -.043 \\
\hline 626: & 34 & 41 & -.043 \\
\hline 627: & 35 & 41 & -.043 \\
\hline 628: & 36 & 41 & -.043 \\
\hline 629: & 37 & 41 & -.043 \\
\hline 630: & 38 & 41 & -.043 \\
\hline 631: & 39 & 41 & -.043 \\
\hline 632: & 40 & 41 & .192 \\
\hline 633: & 40 & 3 & .235 \\
\hline 634: & 40 & 4 & .235 \\
\hline 635: & 40 & 5 & .235 \\
\hline 636: & 40 & 6 & .235 \\
\hline 637: & 40 & 7 & .235 \\
\hline 638: & 40 & 8 & .235 \\
\hline 639: & 40 & 9 & .235 \\
\hline 640: & 40 & 10 & .235 \\
\hline 641: & 40 & 11 & .235 \\
\hline 642: & 40 & 12 & .235 \\
\hline 643: & 40 & 13 & .235 \\
\hline 644: & 40 & 14 & .235 \\
\hline 645: & 40 & 15 & .235 \\
\hline 646: & 40 & 16 & .235 \\
\hline 647: & 40 & 17 & .235 \\
\hline 648: & 40 & 18 & .235 \\
\hline 649: & 40 & 19 & .235 \\
\hline 650: & 40 & 20 & .235 \\
\hline
\end{tabular}


Listing of input for the initial hypothetical-aquifer model

\begin{tabular}{llll}
\hline Line No. & & & \\
\hline $651:$ & 40 & 21 & .235 \\
$652:$ & 40 & 22 & .235 \\
$653:$ & 40 & 23 & .235 \\
$654:$ & 40 & 24 & .235 \\
$655:$ & 40 & 25 & .235 \\
$656:$ & 40 & 26 & .235 \\
$657:$ & 40 & 27 & .235 \\
$658:$ & 40 & 28 & .235 \\
$659:$ & 40 & 29 & .235 \\
$660:$ & 40 & 30 & .235 \\
$661:$ & 40 & 31 & .235 \\
$662:$ & 40 & 32 & .235 \\
$663:$ & 40 & 33 & .235 \\
$664:$ & 40 & 34 & .235 \\
$665:$ & 40 & 35 & .235 \\
$666:$ & 40 & 36 & .235 \\
$667:$ & 40 & 37 & .235 \\
$668:$ & 40 & 38 & .235 \\
$669:$ & 40 & 39 & .235 \\
$670:$ & 40 & 40 & .235
\end{tabular}


APPENDIX B

Listing of input for the revised hypothetical-aquifer model

Line No.

1: HYPOTHETICAL DRAWDOWN MODEL FOR AN EXTENSIVE STRATIFIED DRIFT AQUIFER IN CONN.

2: $200 \times 200-F T$ SPACING. REFERENCE RUN.

3: WATE LEAK EVAP RECH SIP CHEC

4: $\quad 40 \quad 40 \quad 100$

5: CONT $\quad 1 \quad 11400$

6:

7:

8:

9:

10:

11:

$12:$

13:

14:

15:

16:

17:

18:

19:

20:

21:

22:

23:

24:

25:

26:

27:

28:

29:

30:

31:

32:

33:

34:

35:

36:

$37:$

38:

39:

40:

41:

42:

43:

44:

45:

46:

47:

48:

49:

50:

(BLANK LINE)

(BLANK LINE)

(BLANK LINE)

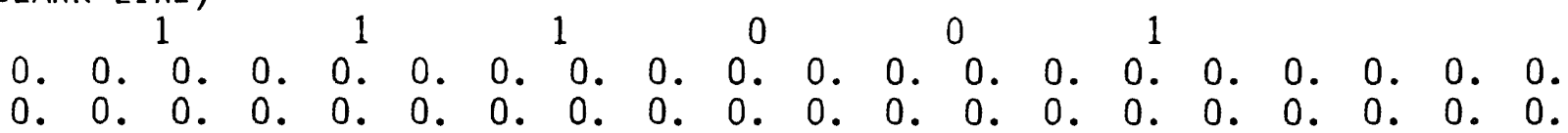
0.144 .144 .144 .144 .144 .143 .143 .143 .143 .143 .142 .142 .142 .142 .142 .141 .141 .141 .141 . 141.140 .140 .140 .140 .140 .139 .139 .139 .139 .139 .138 .138 .138 .138 .137 .137 .137 .137 .0 . 0.146 .146 .145 .145 .145 .145 .145 .145 .144 .144 .144 .144 .144 .143 .143 .143 .143 .143 .142 . 142.142 .142 .142 .141 .141 .141 .141 .141 .140 .140 .140 .140 .140 .139 .139 .139 .139 .139 .0 . 0.147 .147 .147 .147 .147 .147 .146 .146 .146 .146 .146 .145 .145 .145 .145 .145 .144 .144 .144$. 144.144 .143 .143 .143 .143 .143 .143 .142 .142 .142 .142 .142 .141 .141 .141 .141 .141 .140 . 0 . 0.149 .149 .149 .149 .148 .148 .148 .148 .148 .147 .147 .147 .147 .147 .147 .146 .146 .146 .146$. 146.145 .145 .145 .145 .145 .144 .144 .144 .144 .144 .143 .143 .143 .143 .143 .142 .142 .142 . 0 . 0.151 .150 .150 .150 .150 .150 .150 .149 .149 .149 .149 .149 .148 .148 .148 .148 .148 .148 .147$. 147.147 .147 .147 .146 .146 .146 .146 .146 .146 .145 .145 .145 .145 .145 .144 .144 .144 .144 .0 . 0.152 .152 .152 .152 .151 .151 .151 .151 .151 .151 .150 .150 .150 .150 .150 .150 .149 .149 .149 . 149.149 .148 .148 .148 .148 .148 .148 .147 .147 .147 .147 .147 .146 .146 .146 .146 .146 .145 .0 . 0.154 .153 .153 .153 .153 .153 .153 .152 .152 .152 .152 .152 .152 .151 .151 .151 .151 .151 .151 . 150.150 .150 .150 .150 .149 .149 .149 .149 .149 .149 .148 .148 .148 .148 .148 .147 .147 .147 .0 . 0.155 .155 .155 .155 .154 .154 .154 .154 .154 .154 .153 .153 .153 .153 .153 .153 .152 .152 .152 . 152.152 .152 .151 .151 .151 .151 .151 .150 .150 .150 .150 .150 .150 .149 .149 .149 .149 .149 .0 . 0.157 .156 .156 .156 .156 .156 .156 .155 .155 .155 .155 .155 .155 .154 .154 .154 .154 .154 .154 . 153.153 .153 .153 .153 .152 .152 .152 .152 .152 .152 .151 .151 .151 .151 .151 .151 .150 .150 .0 . 0.158 .158 .158 .157 .157 .157 .157 .157 .157 .156 .156 .156 .156 .156 .156 .155 .155 .155 .155$. 155.155 .154 .154 .154 .154 .154 .154 .153 .153 .153 .153 .153 .153 .152 .152 .152 .152 .152 .0 . 0.159 .159 .159 .159 .159 .159 .158 .158 .158 .158 .158 .158 .157 .157 .157 .157 .157 .157 .156 . 156.156 .156 .156 .156 .155 .155 .155 .155 .155 .155 .154 .154 .154 .154 .154 .154 .153 .153 .0$. 0.161 .160 .160 .160 .160 .160 .160 .160 .159 .159 .159 .159 .159 .159 .158 .158 .158 .158 .158 . 158.157 .157 .157 .157 .157 .157 .156 .156 .156 .156 .156 .156 .155 .155 .155 .155 .155 .155 .0$. 0.162 .162 .162 .162 .161 .161 .161 .161 .161 .161 .160 .160 .160 .160 .160 .160 .159 .159 .159 . 159.159.159.158.158.158.158.158.158.157.157.157.157.157.157.157.156.156.156. 0 . 0.163 .163 .163 .163 .163 .162 .162 .162 .162 .162 .162 .162 .161 .161 .161 .161 .161 .161 .160 . 160.160 .160 .160 .160 .159 .159 .159 .159 .159 .159 .159 .158 .158 .158 .158 .158 .158 .157 .0 .

0.164 .164 .164 .164 .164 .164 .164 .163 .163 .163 .163 .163 .163 .163 .162 .162 .162 .162 .162 . 162.161 .161 .161 .161 .161 .161 .160 .160 .160 .160 .160 .160 .160 .159 .159 .159 .159 .159 .0 . 0.166 .166 .165 .165 .165 .165 .165 .165 .165 .164 .164 .164 .164 .164 .164 .163 .163 .163 .163 . 163.163.163.162.162.162.162.162.162.161.161.161.161.161.161.161.160.160.160. 0 . 0.167 .167 .167 .166 .166 .166 .166 .166 .166 .166 .165 .165 .165 .165 .165 .165 .165 .164 .164 . 164.164 .164 .164 .163 .163 .163 .163 .163 .163 .163 .162 .162 .162 .162 .162 .162 .161 .161 .0 . 
Listing of input for the revised hypothetical-aquifer model

Line No.

51: $\quad 0.168 .168 .168 .168 .168 .167 .167 .167 .167 .167 .167 .166 .166 .166 .166 .166 .166 .166 .165$.

52: $\quad 165.165 .165 .165 .165 .165 .164 .164 .164 .164 .164 .164 .163 .163 .163 .163 .163 .163 .163 .0$.

53: $\quad 0.169 .169 .169 .169 .169 .169 .168 .168 .168 .168 .168 .168 .168 .167 .167 .167 .167 .167 .167$.

54:

55:

56:

57:

58:

59:

60:

61:

62:

63:

166.166 .166 .166 .166 .166 .166 .165 .165 .165 .165 .165 .165 .165 .164 .164 .164 .164 .164 .0$.

0.170 .170 .170 .170 .170 .170 .170 .169 .169 .169 .169 .169 .169 .168 .168 .168 .168 .168 .168 .

168.167 .167 .167 .167 .167 .167 .167 .166 .166 .166 .166 .166 .166 .166 .165 .165 .165 .165 .0$.

0.171 .171 .171 .171 .171 .171 .171 .170 .170 .170 .170 .170 .170 .170 .169 .169 .169 .169 .169 . 169.169 .168 .168 .168 .168 .168 .168 .168 .167 .167 .167 .167 .167 .167 .167 .166 .166 .166 .00$.

0.173 .172 .172 .172 .172 .172 .172 .172 .171 .171 .171 .171 .171 .171 .171 .170 .170 .170 .170 . 170.170 .170 .169 .169 .169 .169 .169 .169 .169 .168 .168 .168 .168 .168 .168 .168 .167 .167 .0$. 0.174 .173 .173 .173 .173 .173 .173 .173 .172 .172 .172 .172 .172 .172 .172 .171 .171 .171 .171 . 171.171 .171 .170 .170 .170 .170 .170 .170 .170 .169 .169 .169 .169 .169 .169 .169 .168 .168 . 0 . 0.175 .174 .174 .174 .174 .174 .174 .174 .174 .173 .173 .173 .173 .173 .173 .173 .172 .172 .172 .

64:

65:

66:

67:

68:

69:

70:

71:

72:

73:

74:

75:

76:

77:

78:

79:

80:

81:

82:

83:

84:

85:

86:

87:

88:

89:

90:

91:

92:

93:

$94:$

95:

96:

97:

98:

99:

172.172 .172 .172 .171 .171 .171 .171 .171 .171 .171 .170 .170 .170 .170 .170 .170 .170 .169 .0$. 0.176 .175 .175 .175 .175 .175 .175 .175 .175 .174 .174 .174 .174 .174 .174 .174 .173 .173 .173 . 173.173.173.173.172.172.172.172.172.172.172.171.171.171.171.171.171.171.170. 0 . 0.177 .176 .176 .176 .176 .176 .176 .176 .176 .175 .175 .175 .175 .175 .175 .175 .174 .174 .174 . 174.174 .174 .174 .173 .173 .173 .173 .173 .173 .173 .172 .172 .172 .172 .172 .172 .172 .171 .00$. 0.178 .177 .177 .177 .177 .177 .177 .177 .176 .176 .176 .176 .176 .176 .176 .176 .175 .175 .175$. 175.175 .175 .175 .174 .174 .174 .174 .174 .174 .174 .173 .173 .173 .173 .173 .173 .173 .172 .0 . 0.178 .178 .178 .178 .178 .178 .178 .178 .177 .177 .177 .177 .177 .177 .177 .176 .176 .176 .176 . 176.176 .176 .176 .175 .175 .175 .175 .175 .175 .175 .174 .174 .174 .174 .174 .174 .174 .173 .00 . 0.179 .179 .179 .179 .179 .179 .179 .178 .178 .178 .178 .178 .178 .178 .178 .177 .177 .177 .177 . 177.177 .177 .176 .176 .176 .176 .176 .176 .176 .176 .175 .175 .175 .175 .175 .175 .175 .174 .00$. 0.180 .180 .180 .180 .180 .180 .179 .179 .179 .179 .179 .179 .179 .179 .178 .178 .178 .178 .178 . 178.178 .177 .177 .177 .177 .177 .177 .177 .177 .176 .176 .176 .176 .176 .176 .176 .175 .175 .00$. 0.181 .181 .181 .181 .181 .180 .180 .180 .180 .180 .180 .180 .180 .179 .179 .179 .179 .179 .179 . 179.179 .178 .178 .178 .178 .178 .178 .178 .177 .177 .177 .177 .177 .177 .177 .177 .176 .176 .0 . 0.182 .182 .182 .182 .181 .181 .181 .181 .181 .181 .181 .181 .180 .180 .180 .180 .180 .180 .180 . 180.179 .179 .179 .179 .179 .179 .179 .178 .178 .178 .178 .178 .178 .178 .178 .177 .177 .177 . 0. 0.183 .183 .183 .182 .182 .182 .182 .182 .182 .182 .182 .181 .181 .181 .181 .181 .181 .181 .180 . 180.180 .180 .180 .180 .180 .180 .179 .179 .179 .179 .179 .179 .179 .179 .178 .178 .178 .178 . 0 .

0.184 .183 .183 .183 .183 .183 .183 .183 .183 .182 .182 .182 .182 .182 .182 .182 .182 .181 .181 . 181.181 .181 .181 .181 .181 .180 .180 .180 .180 .180 .180 .180 .180 .179 .179 .179 .179 .179 .00

0.184 .184 .184 .184 .184 .184 .184 .184 .183 .183 .183 .183 .183 .183 .183 .182 .182 .182 .182 . 182.182 .182 .182 .181 .181 .181 .181 .181 .181 .181 .181 .180 .180 .180 .180 .180 .180 .180 .00 . 0.185 .185 .185 .185 .185 .185 .184 .184 .184 .184 .184 .184 .184 .184 .183 .183 .183 .183 .183 . 183.183 .183 .182 .182 .182 .182 .182 .182 .182 .181 .181 .181 .181 .181 .181 .181 .181 .181 .00$. 0.186 .186 .186 .185 .185 .185 .185 .185 .185 .185 .185 .185 .184 .184 .184 .184 .184 .184 .184 . 184.183 .183 .183 .183 .183 .183 .183 .183 .182 .182 .182 .182 .182 .182 .182 .182 .181 .181 .0 . 0.186 .186 .186 .186 .186 .186 .186 .186 .186 .186 .185 .185 .185 .185 .185 .185 .185 .185 .184 . 184.184 .184 .184 .184 .184 .184 .183 .183 .183 .183 .183 .183 .183 .183 .182 .182 .182 .182 .00$.


$\begin{array}{lllllllllllllllllllllllll}0 . & 0 . & 0 . & 0 . & 0 . & 0 . & 0 . & 0 . & 0 . & 0 . & 0 . & 0 . & 0 . & 0 . & 0 . & 0 . & 0 . & 0 . & 0 . & 0 .\end{array}$ (BLANK LINE)

$\begin{array}{rllll}8.68 \mathrm{E}-04 & 0 & 1 & 0 & 0 \\ 0.0 & 0 & 1 & 0 & 0 \\ 0.0 & 0 & 1 & 0 & 0 \\ 4.05 \mathrm{E}-05 & 0 & 1 & 0 & 0 \\ 1 & 1 & 1 & 0 & 0\end{array}$


Listing of input for the revised hypothetical-aquifer model

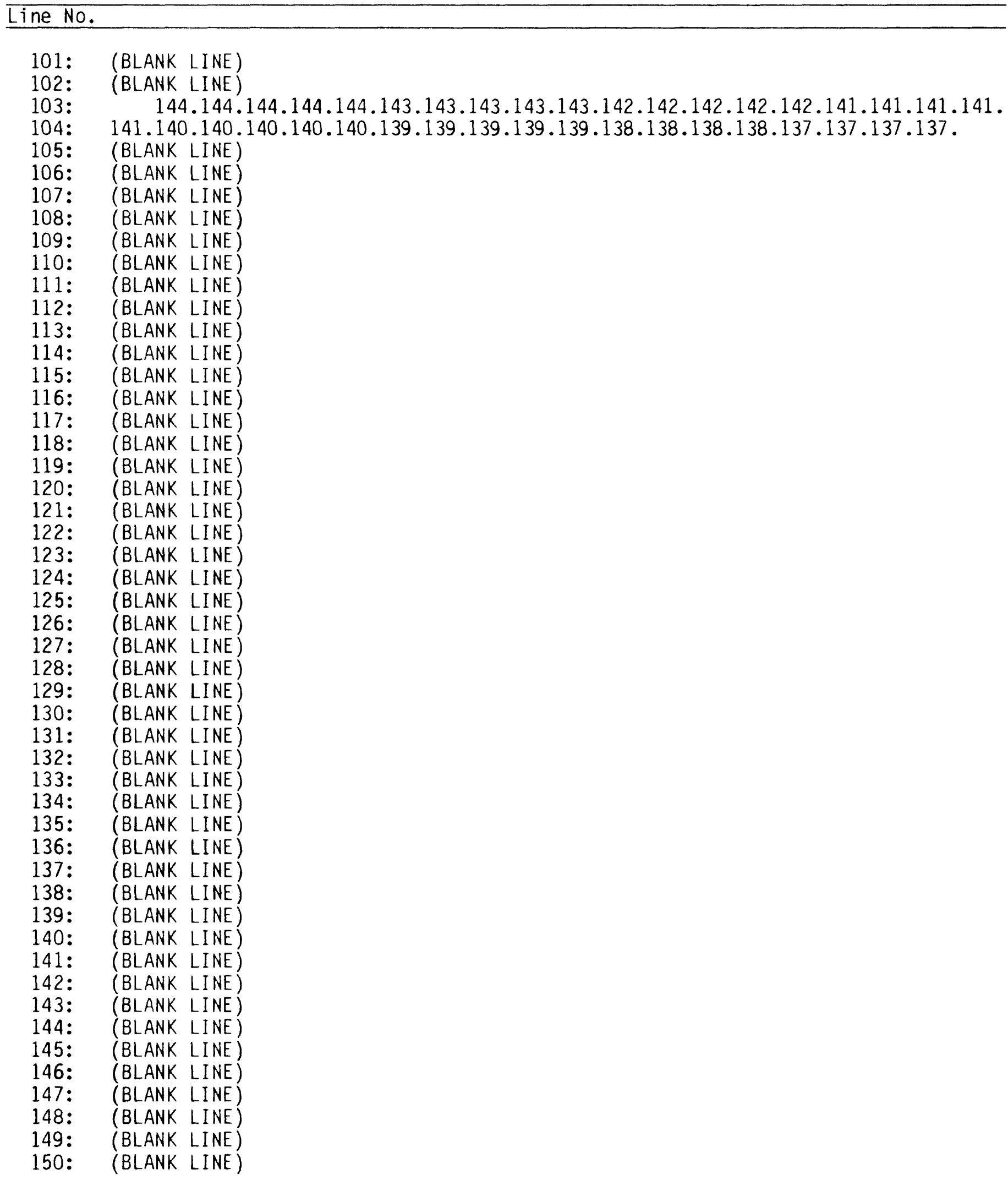


Listing of input for the revised hypothetical-aquifer model

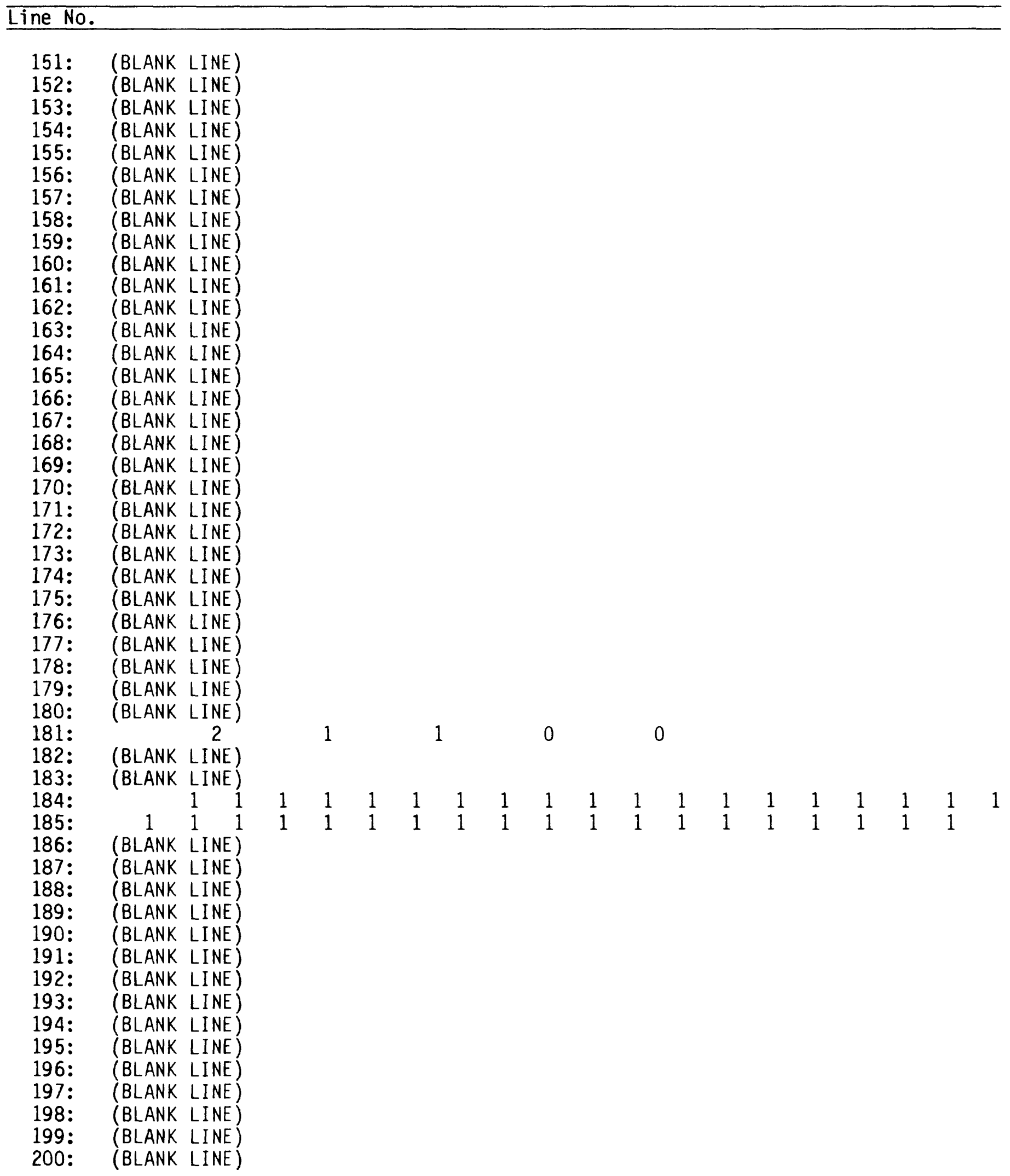


Listing of input for the revised hypothetical-aquifer model

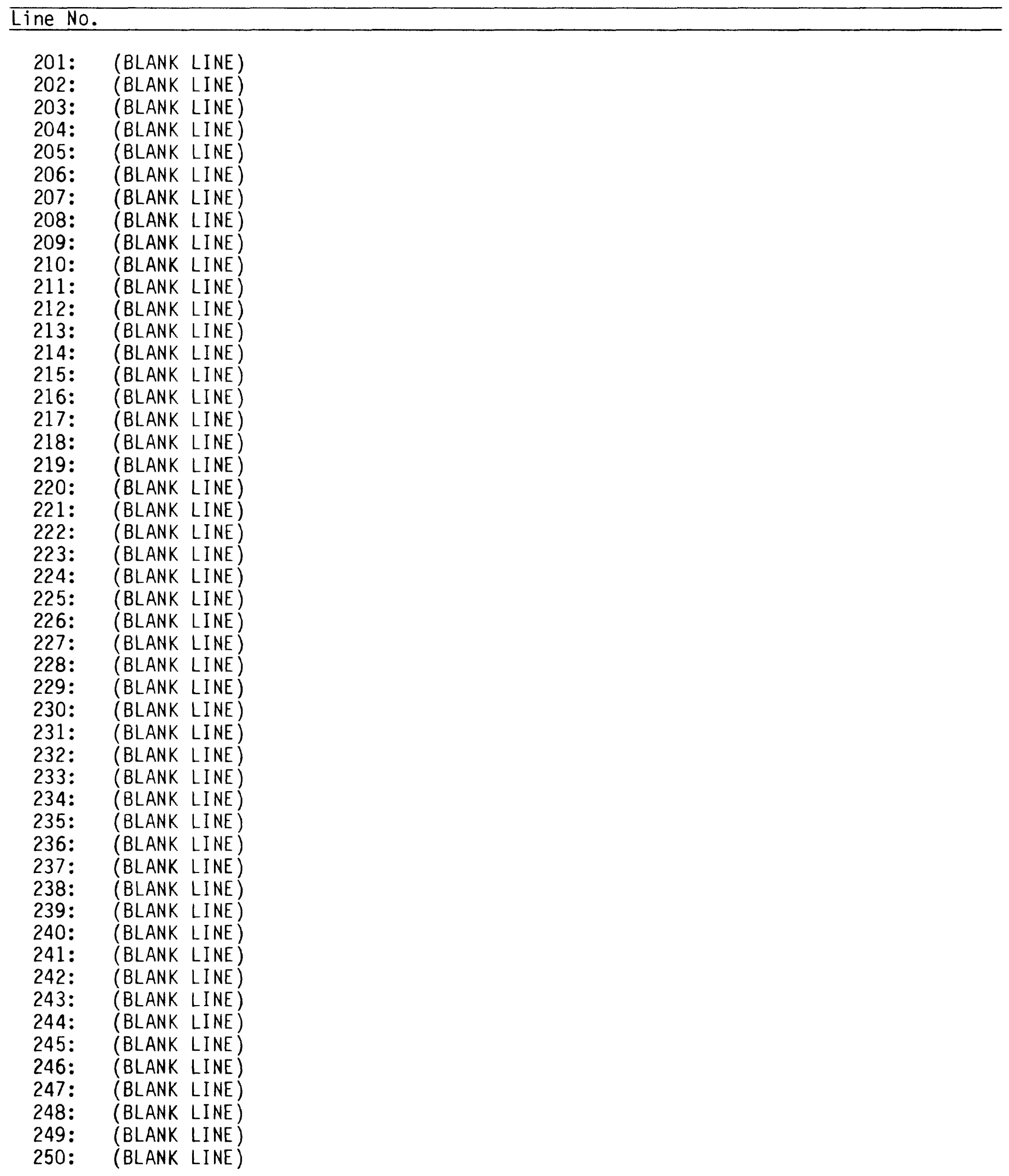


Listing of input for the revised hypothetical-aquifer model

Line No.

251:

252:

253:

254:

255:

256:

257:

258:

259:

260:

261:

262:

263:

264:

265:

266:

267:

268:

269:

270:

271:

272:

273:

274:

275:

276:

277:

278:

279:

280:

281:

282:

283:

284:

285:

286:

287:

288:

289:

290:

291:

292:

293:

294:

295:

296:

297:

298:

299:

300 :
(BLANK LINE)

(BLANK LINE)

(BLANK LINE)

(BLANK LINE)

(BLANK LINE)

(BLANK LINE)

(BLANK LINE)

(BLANK LINE)

(BLANK LINE)

(BLANK LINE)

(BLANK LINE)

(BLANK LINE)

(BLANK LINE)

145.145 .145 .145 .145 .144 .144 .144 .144 .144 .143 .143 .143 .143 .143 .142 .142 .142 .142$.

142.141 .141 .141 .141 .141 .140 .140 .140 .140 .140 .139 .139 .139 .139 .138 .138 .138 .138 . 148.148 .148 .148 .147 .147 .147 .147 .147 .146 .146 .146 .146 .146 .145 .145 .145 .145 .145$.

144.144 .144 .144 .144 .143 .143 .143 .143 .143 .142 .142 .142 .142 .142 .141 .141 .141 .141 . 151.151 .151 .151 .150 .150 .150 .150 .150 .149 .149 .149 .149 .149 .148 .148 .148 .148 .148 .

147.147 .147 .147 .147 .146 .146 .146 .146 .146 .145 .145 .145 .145 .145 .144 .144 .144 .144 . 153.153 .153 .153 .152 .152 .152 .152 .152 .151 .151 .151 .151 .151 .150 .150 .150 .150 .150 .

149.149 .149 .149 .149 .148 .148 .148 .148 .148 .147 .147 .147 .147 .147 .146 .146 .146 .146 . 155.155 .155 .155 .154 .154 .154 .154 .154 .153 .153 .153 .153 .153 .152 .152 .152 .152 .152$. 151.151 .151 .151 .151 .150 .150 .150 .150 .150 .149 .149 .149 .149 .149 .148 .148 .148 .148 . 157.157 .157 .157 .156 .156 .156 .156 .156 .155 .155 .155 .155 .155 .154 .154 .154 .154 .154 . 153.153 .153 .153 .153 .152 .152 .152 .152 .152 .151 .151 .151 .151 .151 .150 .150 .150 .150 . 160.160 .160 .160 .159 .159 .159 .159 .159 .158 .158 .158 .158 .158 .157 .157 .157 .157 .157 . 156.156 .156 .156 .156 .155 .155 .155 .155 .155 .154 .154 .154 .154 .154 .153 .153 .153 .153$. 162.162 .162 .162 .161 .161 .161 .161 .161 .160 .160 .160 .160 .160 .159 .159 .159 .159 .159 . 158.158 .158 .158 .158 .157 .157 .157 .157 .157 .156 .156 .156 .156 .156 .155 .155 .155 .155$. 164.164 .164 .164 .163 .163 .163 .163 .163 .162 .162 .162 .162 .162 .161 .161 .161 .161 .161 .

160.160 .160 .160 .160 .159 .159 .159 .159 .159 .158 .158 .158 .158 .158 .157 .157 .157 .157$. 166.166 .166 .166 .165 .165 .165 .165 .165 .164 .164 .164 .164 .164 .163 .163 .163 .163 .163$.

162.162 .162 .162 .162 .161 .161 .161 .161 .161 .160 .160 .160 .160 .160 .159 .159 .159 .159 . 168.168 .168 .168 .167 .167 .167 .167 .167 .166 .166 .166 .166 .166 .165 .165 .165 .165 .165 .

164.164 .164 .164 .164 .163 .163 .163 .163 .163 .162 .162 .162 .162 .162 .161 .161 .161 .161 . 171.171 .171 .171 .170 .170 .170 .170 .170 .169 .169 .169 .169 .169 .168 .168 .168 .168 .168 .

167.167 .167 .167 .167 .166 .166 .166 .166 .166 .165 .165 .165 .165 .165 .164 .164 .164 .164 . 173.173 .173 .173 .172 .172 .172 .172 .172 .171 .171 .171 .171 .171 .170 .170 .170 .170 .170 . 169.169 .169 .169 .169 .168 .168 .168 .168 .168 .167 .167 .167 .167 .167 .166 .166 .166 .166 . 175.175 .175 .175 .174 .174 .174 .174 .174 .173 .173 .173 .173 .173 .172 .172 .172 .172 .172 . 171.171 .171 .171 .171 .170 .170 .170 .170 .170 .169 .169 .169 .169 .169 .168 .168 .168 .168 . 177.177 .177 .177 .176 .176 .176 .176 .176 .175 .175 .175 .175 .175 .174 .174 .174 .174 .174 . 173.173.173.173.173.172.172.172.172.172.171.171.171.171.171.170.170.170.170. 179.179 .179 .179 .178 .178 .178 .178 .178 .177 .177 .177 .177 .177 .176 .176 .176 .176 .176 . 175.175 .175 .175 .175 .174 .174 .174 .174 .174 .173 .173 .173 .173 .173 .172 .172 .172 .172 . 182.182 .182 .182 .181 .181 .181 .181 .181 .180 .180 .180 .180 .180 .179 .179 .179 .179 .179 . 178.178 .178 .178 .178 .177 .177 .177 .177 .177 .176 .176 .176 .176 .176 .175 .175 .175 .175 . 184.184 .184 .184 .183 .183 .183 .183 .183 .182 .182 .182 .182 .182 .181 .181 .181 .181 .181 . 180.180 .180 .180 .180 .179 .179 .179 .179 .179 .178 .178 .178 .178 .178 .177 .177 .177 .177 . 
Listing of input for the revised hypothetical-aquifer model

Line No.

301:

302:

303:

304:

305:

306:

307:

308:

309:

310:

311:

312:

313:

314:

315:

316:

317:

318:

319:

320:

321 :

322:

323:

324:

325:

326:

327:

328:

329:

330:

331:

332:

333:

334:

335:

336:

337:

338:

339:

340:

341:

342:

343:

344:

345:

346:

347:

348:

349:

350:
186.186 .186 .186 .185 .185 .185 .185 .185 .184 .184 .184 .184 .184 .183 .183 .183 .183 .183$. $182.182 .182 .182 .182 .181 .181 .181 .181 .181 .180 .180 .180 .180 \cdot 180.179 .179 .179 .179$. 188.188 .188 .188 .187 .187 .187 .187 .187 .186 .186 .186 .186 .186 .185 .185 .185 .185 .185$. 184.184 .184 .184 .184 .183 .183 .183 .183 .183 .182 .182 .182 .182 .182 .181 .181 .181 .181$. 189.189 .189 .189 .188 .188 .188 .188 .188 .187 .187 .187 .187 .187 .186 .186 .186 .186 .186$. 185.185 .185 .185 .185 .184 .184 .184 .184 .184 .183 .183 .183 .183 .183 .182 .182 .182 .182 . 191.191 .191 .191 .190 .190 .190 .190 .190 .189 .189 .189 .189 .189 .188 .188 .188 .188 .188 . 187.187 .187 .187 .187 .186 .186 .186 .186 .186 .185 .185 .185 .185 .185 .184 .184 .184 .184$. 192.192 .192 .192 .191 .191 .191 .191 .191 .190 .190 .190 .190 .190 .189 .189 .189 .189 .189$. 188.188 .188 .188 .188 .187 .187 .187 .187 .187 .186 .186 .186 .186 .186 .185 .185 .185 .185$. 193.193 .193 .193 .192 .192 .192 .192 .192 .191 .191 .191 .191 .191 .190 .190 .190 .190 .190 . 189.189 .189 .189 .189 .188 .188 .188 .188 .188 .187 .187 .187 .187 .187 .186 .186 .186 .186$. 194.194 .194 .194 .193 .193 .193 .193 .193 .192 .192 .192 .192 .192 .191 .191 .191 .191 .191 . 190.190 .190 .190 .190 .189 .189 .189 .189 .189 .188 .188 .188 .188 .188 .187 .187 .187 .187 . 195.195 .195 .195 .194 .194 .194 .194 .194 .193 .193 .193 .193 .193 .192 .192 .192 .192 .192 . 191.191 .191 .191 .191 .190 .190 .190 .190 .190 .189 .189 .189 .189 .189 .188 .188 .188 .188$. 197.197 .197 .197 .196 .196 .196 .196 .196 .195 .195 .195 .195 .195 .194 .194 .194 .194 .194$. 193.193 .193 .193 .193 .192 .192 .192 .192 .192 .191 .191 .191 .191 .191 .190 .190 .190 .190$. 198.198 .198 .198 .197 .197 .197 .197 .197 .196 .196 .196 .196 .196 .195 .195 .195 .195 .195$. 194.194.194.194.194.193.193.193.193.193.192.192.192.192.192.191.191.191.191. 199.199 .199 .199 .198 .198 .198 .198 .198 .197 .197 .197 .197 .197 .196 .196 .196 .196 .196$. 195.195.195.195.195.194.194.194.194.194.193.193.193.193.193.192.192.192.192. 200.200.200.200.199.199.199.199.199.198.198.198.198.198.197.197.197.197.197.

196.196 .196 .196 .196 .195 .195 .195 .195 .195 .194 .194 .194 .194 .194 .193 .193 .193 .193$. 201.201 .201 .201 .200 .200 .200 .200 .200 .199 .199 .199 .199 .199 .198 .198 .198 .198 .198$.

197.197 .197 .197 .197 .196 .196 .196 .196 .196 .195 .195 .195 .195 .195 .194 .194 .194 .194$. 203.203.203.203.202.202.202.202.202.201.201.201.201.201.200.200.200.200.200. 199.199.199.199.199.198.198.198.198.198.197.197.197.197.197.196.196.196.196. 204.204.204.204.203.203.203.203.203.202.202.202.202.202.201.201.201.201.201. 200.200 .200 .200 .200 .199 .199 .199 .199 .199 .198 .198 .198 .198 .198 .197 .197 .197 .197 . 205.205.205.205.204.204.204.204.204.203.203.203.203.203.202.202.202.202.202 . 201.201 .201 .201 .201 .200 .200 .200 .200 .200 .199 .199 .199 .199 .199 .198 .198 .198 .198 . 206.206 .206 .206 .205 .205 .205 .205 .205 .204 .204 .204 .204 .204 .203 .203 .203 .203 .203 . 202.202 .202 .202 .202 .201 .201 .201 .201 .201 .200 .200 .200 .200 .200 .199 .199 .199 .199 . 207.207 .207 .207 .206 .206 .206 .206 .206 .205 .205 .205 .205 .205 .204 .204 .204 .204 .204 . 203.203.203.203.203.202.202.202.202.202.201.201.201.201.201.200.200.200.200. 209.209.290.209.208.208.208.208.208.207.207.207.207.207.206.206.206.206.206 . 205.205.205.205.205.204.204.204.204.204.203.203.203.203.203.202.202.202.202. 210.210 .210 .210 .209 .209 .209 .209 .209 .208 .208 .208 .208 .208 .207 .207 .207 .207 .207 • 206.206 .206 .206 .206 .205 .205 .205 .205 .205 .204 .204 .204 .204 .204 .203 .203 .203 .203 .

(BLANK LINE)

(BLANK LINE)

$\begin{array}{rrr}6.61 \mathrm{E}-08 & 0 & 1 \\ 200 & 0 & 1 \\ 200 & 0 & 1 \\ 1 & 0 & 110 \\ 3 & 2 & .02 \\ 4 & 2 & .02 \\ 5 & 2 & .02 \\ 6 & 2 & .02\end{array}$


Listing of input for the revised hypothetical-aquifer model

Line No.

$\begin{array}{lrrl}\text { 351: } & 7 & 2 & .02 \\ \text { 352: } & 8 & 2 & .02 \\ \text { 353: } & 9 & 2 & .02 \\ \text { 354: } & 10 & 2 & .02 \\ \text { 355: } & 11 & 2 & .02 \\ \text { 356: } & 12 & 2 & .02 \\ \text { 357: } & 13 & 2 & .02 \\ 358: & 14 & 2 & .02 \\ 359: & 15 & 2 & .02 \\ 360: & 16 & 2 & .02 \\ 361: & 17 & 2 & .02 \\ 362: & 18 & 2 & .02 \\ 363: & 19 & 2 & .02 \\ 364: & 20 & 2 & .02 \\ 365: & 21 & 2 & .02 \\ 366: & 22 & 2 & .02 \\ 367: & 23 & 2 & .02 \\ 368: & 24 & 2 & .02 \\ 369: & 25 & 2 & .02 \\ 370: & 26 & 2 & .02 \\ 371: & 27 & 2 & .02 \\ 372: & 28 & 2 & .02 \\ 373: & 29 & 2 & .02 \\ 374: & 30 & 2 & .02 \\ 375: & 31 & 2 & .02 \\ 376: & 32 & 2 & .02 \\ 377: & 33 & 2 & .02 \\ 378: & 34 & 2 & .02 \\ 379: & 35 & 2 & .02 \\ 380: & 36 & 2 & .02 \\ 381: & 37 & 2 & .02 \\ 382: & 38 & 2 & .02 \\ 383: & 39 & 2 & .11 \\ 384: & 3 & 39 & -.02 \\ 385: & 4 & 39 & -.02 \\ 386: & 5 & 39 & -.02 \\ 387: & 6 & 39 & -.02 \\ 388: & 7 & 39 & -.02 \\ 389: & 8 & 39 & -.02 \\ 390: & 9 & 39 & -.02 \\ 391: & 10 & 39 & -.02 \\ 392: & 11 & 39 & -.02 \\ 391: & 12 & 39 & -.02 \\ 394: & 13 & 39 & -.02 \\ 395: & 14 & 39 & -.02 \\ 396: & 15 & 39 & -.02 \\ 397: & 16 & 39 & -.02 \\ 398: & 17 & 39 & -.02 \\ 399: & 18 & 39 & -.02 \\ \text { 400: } & 19 & 39 & -.02 \\ & & & \end{array}$


Listing of input for the revised hypothetical-aquifer model




Listing of input for the revised hypothetical-aquifer model

Line No.

$\begin{array}{llll}\text { 451: } & 39 & 33 & .11 \\ \text { 452: } & 39 & 34 & .11 \\ \text { 453: } & 39 & 35 & .11 \\ \text { 454: } & 39 & 36 & .11 \\ \text { 455: } & 39 & 37 & .11 \\ \text { 456: } & 39 & 38 & .11\end{array}$


APPENDIX C

Listing of input for the Farmington aquifer mode?

Line No.

1: STEADY-STATE SIMULATION OF THE FARMINGTON AQUIFER, FIELD KAVE AND 25 INCHES OF $R$

2: ECHARGE. REFERENCE RUN.

3: WATE LEAK EVAP RECH SIP CHEC

$\begin{array}{llrlrlll}\text { 4: } & & 42 & 72 & 0 & 50 & 4 & \\ \text { 5: } & \text { CONT } & & 1 & 1 & 667 & 1 & 1\end{array}$

6:

7:

8:

9:

10:

11:

12:

13:

14:

15:

16:

17:

18:

19:

20 :

$21:$

22:

23:

24:

25:

26:

27:

28:

29:

$30:$

$31:$

32:

33:

$34:$

$35:$

36 :

37:

$38:$

39 :

40 :

41:

42:

43:

44:

45:

46 :

47:

48:

49:

50 :

(BLANK LINE)

(BLANK LINE)

(BLANK LINE)


$\begin{array}{llllllllllllllllllllllllll}0 . & 0 . & 0 . & 0 . & 0 . & 0 . & 0 . & 0 . & 0 . & 0 . & 0 . & 0 . & 0 . & 0 . & 0 . & 0 . & 0 . & 0 . & 0 . & 0 .\end{array}$

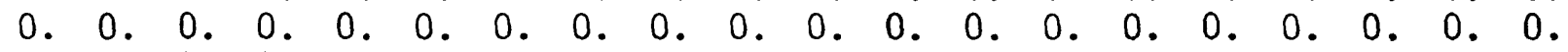

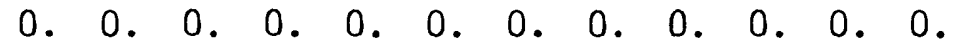

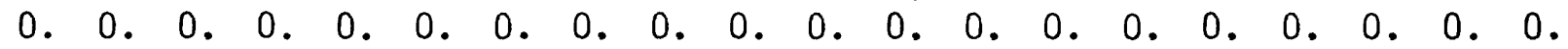



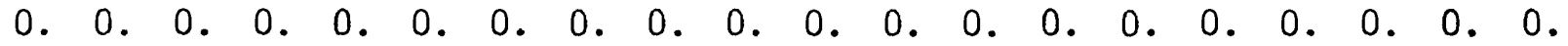
0.0 .0 .0 .0 .0 .533 .417 .353 .316 .319 .0 . 0.

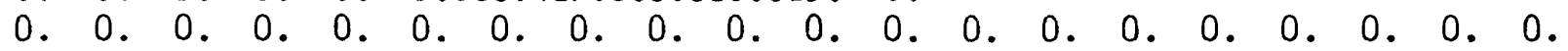

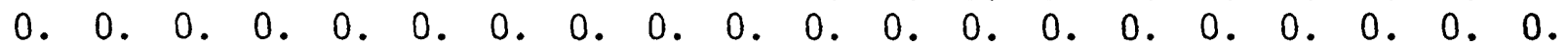
$\begin{array}{llllllllllllllllllllllllllllll}0 . & 0 . & 0 . & 0 . & 0 . & 0 . & 0 . & 0 . & 0 . & 0 . & 0 . & 0 . & 0 . & 0 . & 0 . & 0 . & 0 . & 0 . & 0 . & 0 .\end{array}$ 0.0 .0 .0 .0 .382 .345 .237 .232 .232 .272 .0 .

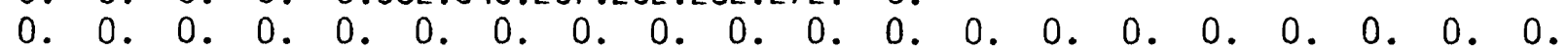


0.0 .0 .0 .0 .0 .0 .0 .0 .0 .277 .276 .274 .271 .268 .265 .264 .262 .261 .259 . 252.236.225.224.233.236.221.209.214.219.219. 0 .

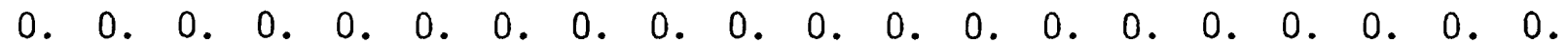

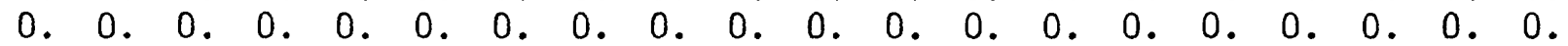
0. 0.0 .0 .0 .0 .0 .0 .0 .0 .280 .277 .275 .273 .270 .267 .264 .261 .257 .253 . 238.214.204.198.198.198.199.204.271.294.313. 0 .

$\begin{array}{llllllllllllllllllll}0 . & 0 . & 0 . & 0 . & 0 . & 0 . & 0 . & 0 . & 0 . & 0 . & 0 . & 0 . & 0 . & 0 . & 0 . & 0 . & 0 . & 0 . & 0 . & 0 .\end{array}$ 0 . 0.0 .0 .0 .377 .377 .377 .378 .379 .380 .382 .384 .385 .387 .390 .391 .392 .391 .391 . 389.387 .385 .382 .378 .374 .370 .365 .360 .351 .336 .319 .305 .291 .277 .268 .265 .261 .256 .251 . 232.207.197.189.189.194.207.217.287. 0.0 .0 .

$\begin{array}{llllllllllllllllllll}0 . & 0 . & 0 . & 0 . & 0 . & 0 . & 0 . & 0 . & 0 . & 0 . & 0 . & 0 . & 0 . & 0 . & 0 . & 0 . & 0 . & 0 . & 0 . & 0 .\end{array}$ 0.0 .0 .0 .0 .369 .370 .370 .370 .370 .370 .370 .370 .370 .369 .369 .368 .367 .365 .364 . 361.359 .356 .352 .348 .343 .338 .331 .324 .311 .301 .296 .291 .286 .280 .274 .268 .261 .254 .247 . 225.201.192.184.192.204.220.230.292. 0.0 . 0 .

$\begin{array}{llllllllllllllllllll}0 . & 0 . & 0 . & 0 . & 0 . & 0 . & 0 . & 0 . & 0 . & 0 . & 0 . & 0 . & 0 . & 0 . & 0 . & 0 . & 0 . & 0 . & 0 . & 0 .\end{array}$

0.0 .0 .0 .0 .361 .361 .361 .361 .361 .360 .359 .358 .357 .355 .353 .351 .349 .346 .343 . 340.336 .331 .326 .320 .315 .311 .306 .302 .296 .291 .287 .281 .276 .270 .264 .258 .251 .244 .235 , 212.194 .189 .186 .195 .222 .244 .257 .306 .0 .0 .0$.

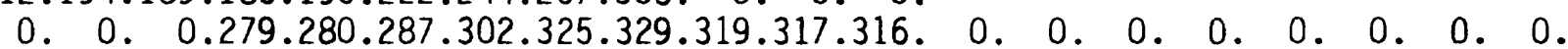

0.0 .0 .0 .0 .354 .354 .354 .353 .353 .352 .350 .348 .346 .343 .340 .337 .333 .328 .323 . 318.314 .310 .306 .301 .296 .292 .288 .283 .278 .273 .267 .261 .254 .246 .239 .233 .226 .217 .204 . 
Listing of input for the Farmington aquifer mode 1

Line No.

51: $\quad 193.188 .184 .185 .205 .248 .273 .316 .337 .0 .0 .0$.

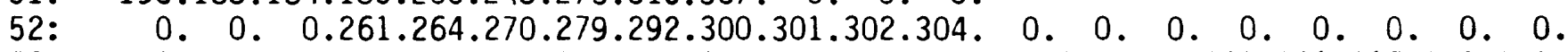

53: $\quad 0.0 .0 .0 .0 .350 .350 .349 .347 .345 .342 .339 .336 .333 .329 .325 .321 .315 .308 .301$. 54: $\quad 297.293 .288 .282 .274 .266 .259 .253 .247 .241 .235 .231 .227 .223 .218 .214 .210 .205 .200 .194$.



56:

57:

58:

59:

60:

61:

62:

63:

64:

65:

66:

67:

68:

69:

70 :

71:

72 :

73:

74 :

75:

76:

77:

78:

79 :

80:

81:

82:

83:

84:

85:

86:

87:

88:

89:

90:

91:

92:

93:

94:

95:

96:

97:

98:

99:

100:

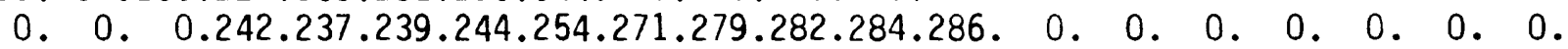

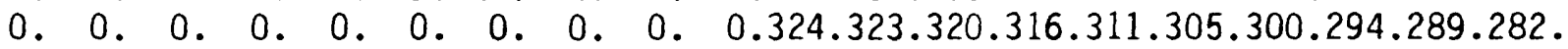
276.270 .262 .252 .231 .214 .213 .211 .208 .206 .204 .202 .200 .198 .196 .193 .191 .189 .187 .186 . 183.179 .201 .286 .310 .316 .326 .349 . 0.0 . 0.0 .0 .

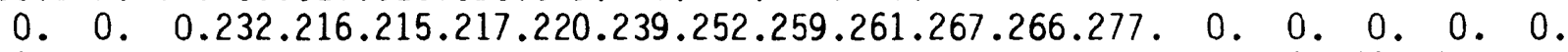

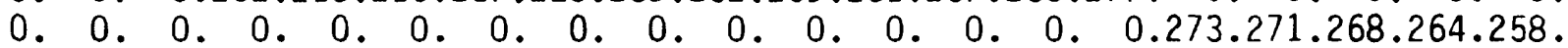
251.245 .238 .229 .213 .200 .199 .197 .195 .193 .191 .189 .186 .184 .181 .179 .177 .176 .176 .176 . 179.179.213.289. 0.0 .0 .0 .0 .0 .0 .0 . 0.00.

0. $0 . \quad 0.225 .210 .210 .210 .211 .216 .224 .235 .238 .235 .235 .245 .238 .237 .236 .235 .235$. 234.234 .233 .233 .233 .233 .233 .233 .233 .234 .238 .241 .243 .245 .245 .245 .242 .238 .229 .219 . 214.211 .207 .201 .194 .189 .187 .185 .182 .179 .176 .173 .169 .169 .169 .173 .174 .174 .175 .176 . 181.187 .221 .295 . 0.0 .0 .0 .0 .0 .0 .0 .006

0. 0. 0.219.205.205.205.203.200.200.207.208.206.204.200.201.201.201.201.201. 201.201 .201 .201 .201 .201 .201 .201 .200 .200 .199 .198 .198 .197 .197 .196 .196 .195 .194 .193 . 193.191 .189 .186 .180 .175 .175 .173 .172 .170 .169 .168 .167 .169 .171 .173 .175 .176 .178 .179 . 185.193.212.279. 0.0 .0 .0 .0 .0 .0 .0$.

0. 0. 0.209 .195 .196 .196 .195 .193 .190 .185 .183 .180 .178 .176 .175 .175 .174 .174 .174 . $173.173 .173 .173 .173 .173 .173 .173 .172 .172 .172 .172 .172 .171 .171 .171 .171 .170 \cdot 170.169$. 168.168 .167 .166 .166 .165 .165 .164 .164 .164 .164 .165 .165 .168 .170 .173 .175 .178 .180 .182 . 188.199.208.226.233.237.238. 0.0 . 0.0 . 0 .

0 . 0.0 .166 .166 .181 .185 .186 .184 .181 .178 .176 .174 .172 .169 .168 .167 .167 .166 .166 . 166.166 .165 .165 .165 .165 .165 .165 .165 .166 .166 .166 .166 .166 .166 .166 .166 .166 .165 .165 . 165.164 .164 .164 .164 .164 .164 .164 .166 .167 .169 .170 .172 .173 .175 .177 .179 .181 .183 .185 . 190.200 .207 .216 .222 .225 .227 . 0.0 .0 .0 .0 . 0.

0. 0.0 .182 .165 .176 .180 .181 .180 .177 .174 .173 .171 .169 .166 .164 .163 .163 .162 .162 . 162.161 .161 .161 .161 .161 .161 .162 .162 .163 .163 .163 .164 .164 .164 .164 .164 .164 .163 .164 . 164.164 .164 .164 .165 .166 .167 .168 .169 .170 .171 .173 .174 .175 .177 .178 .180 .181 .183 .184 . 190.199.207.212.217.220.222. 0 . 0.0 .0 .0 . 0.

0 . $0.0 .186 .165 .174 .178 .179 .177 .175 .172 .171 .170 .168 .165 .163 \cdot 162.161 .161 .160$. 160.160 .160 .160 .160 .160 .160 .161 .161 .162 .162 .163 .163 .163 .163 .163 .163 .163 .163 .163 . 164.164 .164 .165 .165 .166 .167 .169 .170 .171 .172 .173 .175 .176 .177 .178 .180 .181 .183 .184 . 190.199 .206 .211 .216 .219 .221 . 0.0 .0 .0 .0 . 0.

0 . 0.0 .189 .165 .173 .176 .176 .175 .172 .171 .169 .169 .167 .164 .162 .161 .159 .159 .159 . 159.159 .159 .159 .159 .159 .159 .159 .160 .161 .162 .162 .162 .163 .163 .163 .163 .163 .163 .163 . 163.164 .164 .165 .166 .167 .168 .169 .170 .171 .172 .174 .175 .176 .177 .179 .180 .182 .183 .184 . 190.198 .205 .210 .215 .218 .219 . 0.0 .0 .0 .0$.

0. 0. 0.192.165.171.173.174.172.170.169.167.167.166.163.161.160.159.159.159. 159.159 .159 .159 .159 .159 .159 .159 .160 .160 .161 .162 .162 .162 .162 .163 .163 .163 .163 .163 . 164.164 .165 .166 .166 .167 .169 .170 .171 .172 .173 .174 .175 .177 .178 .179 .181 .182 .183 .184 . 189.198.205.209.213.216.218. 0.0 . 0.0 .0$.

0 . 0. 0.195 .165 .169 .171 .171 .169 .168 .166 .165 .166 .165 .162 .160 .159 .159 .159 .159 . 159.159 .159 .159 .159 .159 .159 .159 .159 .160 .161 .161 .161 .162 .162 .162 .162 .162 .163 .163 . 164.165 .165 .166 .167 .168 .169 .170 .171 .172 .174 .175 .176 .177 .178 .179 .181 .182 .183 .184 . 189.197 .204 .207 .212 .215 .216 . 0.0 .0 .0 .0$.

0 . 0.0 .199 .165 .167 .169 .168 .167 .165 .164 .163 .165 .164 .160 .159 .159 .158 .158 .159 . 
Listing of input for the Farmington aquifer model

Line No.

101: $\quad 159.159 .159 .159 .159 .159 .159 .159 .159 .160 .160 .161 .161 .161 .162 .162 .162 .162 .163 .163$.

102: $\quad 164.165 .166 .167 .168 .169 .170 .171 .172 .173 .174 .175 .176 .177 .178 .180 .181 .182 .184 .185$.

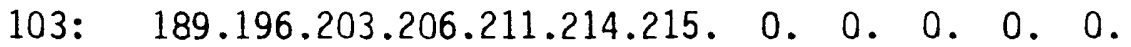

104:

105:

106:

107:

108:

109:

110:

111:

112:

113:

114:

115:

116:

117:

118:

119:

120:

121:

122:

123:

124:

125:

126:

127:

128:

129:

130:

131:

132:

133:

134:

135:

136:

137:

138:

139:

140:

141:

0 . 0.0 .204 .165 .166 .166 .166 .164 .163 .162 .161 .164 .163 .159 .158 .158 .158 .158 .159 . 159.159 .159 .159 .159 .159 .159 .159 .159 .159 .160 .161 .161 .161 .161 .162 .162 .162 .163 .164 . 164.165 .166 .167 .168 .169 .170 .171 .172 .173 .174 .176 .177 .178 .179 .180 .181 .183 .184 .185 . 189.196 .202 .206 .210 .213 .214 . 0.0 .0 .0 .0 .0$.

0.0 .0 .209 .165 .164 .164 .163 .162 .160 .159 .159 .163 .162 .157 .158 .158 .158 .158 .159 . 159.159 .159 .159 .159 .159 .159 .159 .159 .159 .161 .161 .161 .161 .161 .162 .162 .162 .163 .164 . 165.166 .167 .168 .169 .170 .171 .172 .173 .174 .175 .176 .177 .178 .179 .180 .182 .183 .184 .185 .

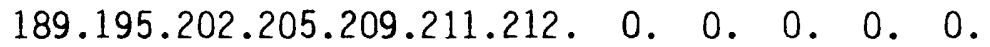

0 . 0.0 .216 .171 .168 .167 .168 .166 .163 .161 .159 .162 .162 .157 .158 .158 .158 .158 .159 . 159.159 .159 .159 .159 .159 .159 .159 .159 .160 .160 .161 .161 .161 .161 .162 .162 .163 .163 .164 . 165.166 .167 .168 .169 .170 .171 .172 .173 .174 .175 .176 .177 .178 .179 .180 .182 .183 .184 .185 . 189.195.201.204.208.210.211. 0. 0. 0. 0.0 .

0.0 .0 .224 .176 .172 .170 .172 .170 .166 .162 .159 .161 .161 .157 .158 .158 .158 .159 .159 . 159.159 .159 .159 .159 .159 .159 .160 .160 .160 .160 .161 .161 .161 .162 .162 .163 .163 .164 .165 . 165.167 .168 .168 .169 .170 .171 .172 .173 .174 .175 .176 .177 .178 .179 .181 .182 .183 .184 .186 . 189.195 .200 .204 .207 .209 .210 . 0. 0. 0. 0. 0.0 .

0.0 .0 .235 .191 .185 .179 .176 .174 .170 .164 .159 .161 .161 .157 .158 .158 .158 .159 .159 . 159.159 .159 .160 .160 .160 .160 .160 .160 .160 .161 .161 .161 .162 .162 .163 .163 .164 .164 .165 . 166.167 .168 .169 .170 .171 .172 .173 .174 .174 .175 .176 .177 .179 .180 .181 .182 .183 .184 .186 . 189.194.200.203.205.207.208. 0.0 .0 .0 .0$.

0 . 0.0 .246 .211 .203 .191 .181 .178 .173 .167 .159 .160 .160 .157 .158 .158 .158 .159 .159 . 159.159 .160 .160 .160 .160 .160 .160 .161 .161 .161 .161 .162 .162 .163 .163 .164 .164 .165 .166 . 166.167 .168 .169 .170 .171 .172 .173 .174 .175 .176 .177 .178 .179 .180 .181 .182 .183 .185 .186 . 189.194.199.202.204.206.206. 0.0 .0 .0 .0 .0$.

0.0 .0 .257 .226 .216 .201 .186 .181 .176 .169 .159 .159 .160 .157 .158 .158 .158 .159 .159 . 159.160 .160 .160 .160 .160 .160 .161 .161 .161 .161 .162 .162 .163 .163 .164 .164 .165 .165 .166 . 167.168 .169 .169 .170 .171 .172 .173 .174 .175 .176 .177 .178 .179 .180 .181 .182 .183 .185 .186 .

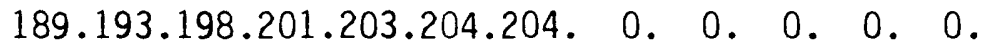

0 . 0.0 .267 .238 .228 .210 .190 .185 .179 .171 .162 .159 .159 .157 .158 .158 .158 .159 .159 . 159.160 .160 .160 .160 .160 .161 .161 .161 .161 .162 .162 .162 .163 .163 .164 .164 .165 .166 .166 . 167.168 .169 .170 .170 .171 .172 .173 .174 .175 .176 .177 .178 .179 .180 .181 .182 .183 .185 .186 . 189.193 .197 .201 .202 .202 .202 . 0.0 .0 .0 .0 .0$.

0.0 .0 .277 .249 .238 .219 .193 .188 .182 .173 .164 .159 .159 .157 .158 .158 .158 .159 .159 . 159.160 .160 .160 .160 .160 .161 .161 .161 .161 .162 .162 .163 .163 .163 .164 .165 .165 .166 .167 . 167.168 .169 .170 .171 .171 .172 .173 .174 .175 .176 .177 .178 .179 .180 .181 .182 .183 .185 .186 . 188.192.196.200.200.201.200. 0.0 .0 .0 .0 .0$.

0.0 .0 .316 .280 .268 .246 .213 .202 .194 .184 .173 .159 .159 .157 .158 .158 .158 .159 .159 . 159.159 .160 .160 .160 .160 .161 .161 .161 .162 .162 .162 .163 .163 .163 .164 .165 .166 .166 .167 . 142: $\quad 168.169 .169 .170 .171 .172 .173 .173 .174 .175 .176 .177 .178 .179 .180 .181 .182 .183 .184 .186$.

143:

144:

145:

146:

147:

148:

149:

150:

188.191.193.195.196.196.196. 0.0 .0 .0 .0 .0 .00$.

0.0 .0 .415 .400 .405 .384 .362 .347 .328 .268 .205 .159 .158 .157 .157 .157 .157 .157 .157 . 157.158 .158 .158 .159 .159 .159 .160 .160 .160 .160 .161 .161 .162 .162 .162 .163 .164 .165 .165 . 166.167 .167 .168 .169 .170 .170 .171 .172 .173 .174 .175 .176 .176 .177 .178 .179 .180 .181 .182 . 184.188 .189 .189 .189 .189 .189 .0 .0 .0 .0 .0$.

0.0 .0 .0 .0 .0 .0 .0 .0 .0 .0 .310 .250 .231 .213 .184 .157 .156 .154 .154 .154 . 154.154 .154 .155 .156 .156 .157 .157 .158 .158 .159 .159 .159 .160 .160 .160 .161 .161 .162 .162 . 163.163 .164 .164 .165 .165 .166 .167 .168 .169 .169 .170 .171 .172 .173 .174 .175 .175 .176 .177 . 
Listing of input for the Farmington aquifer mode?

Line No.

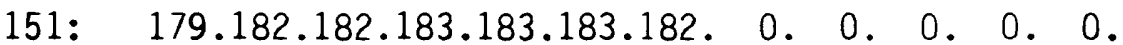

152:

153:

154:

155:

156:

157:

158:

159:

160:

161:

162:

163:

164:

165:

166:

167:

168:

169:

170:

171:

172:

173:

174:

175:

176:

177:

178:

179:

180:

181:

182:

183:

184:

185:

186:

187:

188:

189:

190:

191:

192:

0.0 .0 .0 .0 .0 .0 .0 .0 .0 .339 .278 .257 .239 .207 .170 .167 .164 .163 .161 . 159.157 .154 .154 .154 .154 .154 .154 .155 .155 .156 .156 .157 .157 .157 .157 .158 .158 .158 .159 . 159.159 .160 .160 .160 .161 .161 .162 .162 .163 .163 .164 .165 .166 .166 .167 .167 .168 .168 .169 .

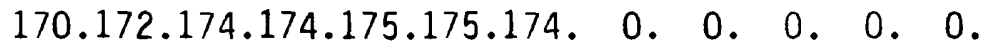

0. 0.0 .0 .0 .0 .0 .0 .0 .0 .0 .367 .330 .301 .296 .237 .215 .208 .202 .194 .182 . 172.170 .168 .165 .162 .159 .157 .154 .154 .154 .154 .154 .154 .154 .154 .154 .154 .154 .154 .154 . 154.154 .154 .155 .156 .157 .157 .158 .158 .158 .158 .158 .159 .159 .159 .159 .159 .160 .160 .160 . 161.162 .165 .166 .166 .165 .164 .0 .0 .0 .0 .0$.

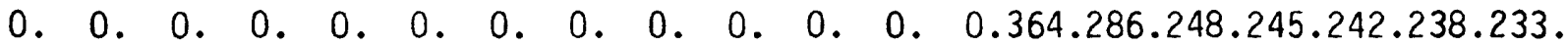
227.222 .217 .214 .210 .207 .204 .201 .199 .196 .193 .191 .187 .182 .175 .169 .168 .167 .165 .163 . 160.158 .154 .154 .154 .154 .154 .154 .154 .154 .154 .154 .154 .154 .154 .154 .154 .154 .154 .154 . 154.154 .154 .158 .154 .154 .154 .0 .0 .0 .0 .0$.

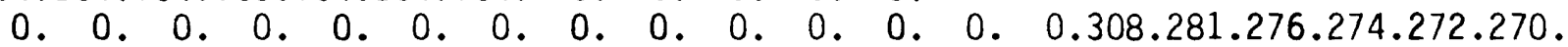
269.267 .265 .264 .262 .261 .259 .258 .256 .254 .251 .248 .245 .241 .236 .230 .225 .221 .217 .212 . 208.205.203.201.199.198.197.196.196.195.194.193.192.191.190.189.188.187.186.184. 179.164 .154 .154 .154 .161 .162 . 0.0 .0 .0 .0 . 0.

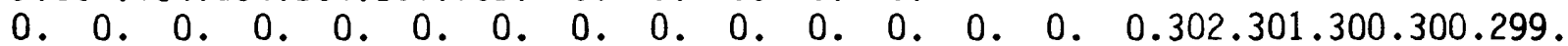
298.298 .297 .297 .296 .295 .294 .293 .292 .291 .290 .288 .287 .285 .283 .280 .278 .276 .274 .272 . 269.266 .263 .260 .258 .256 .254 .253 .252 .251 .250 .248 .247 .246 .243 .240 .238 .237 .236 .235 . 229.202 .191 .187 .187 .196 .227 . 0.0 .0 .0 .0 . 0.

0. 0.0 .0 .0 .0 .0 .0 .0 .0 .0 .0 .0 .0 .0 .0 .0 .327 .326 .326 .326 .326 . $326.326 .326 .327 .328 .328 .329 \cdot 329.329 .329 .328 .328 \cdot 327.325 .323 .321 \cdot 317.313 \cdot 310.308$. 306.303 .301 .298 .295 .292 .290 .288 .286 .286 .285 .286 .286 .287 .288 .297 .311 .322 .334 .347 . 368.331 .323 .321 .322 .327 .347 .0 .0 .0 .0 .0$.

$\begin{array}{lllllllllllllll}0 . & 0 . & 0 . & 0 . & 0 . & 0 . & 0 . & 0 . & 0 . & 0 . & 0 . & 0 . & 0 . & 0 . & 0.350 .350 .350 .351 .353 \text {. }\end{array}$ 375.402 .420 .436 .452 .474 .490 .501 .509 .516 .523 .525 .520 .510 .495 .474 .455 .438 .420 .399 . 380.371 .364 .359 .356 .353 .350 .348 .348 .347 .348 .349 .350 .353 .357 .362 .368 .372 .375 .376 .

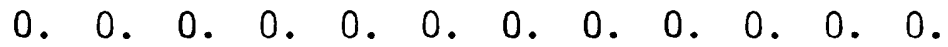

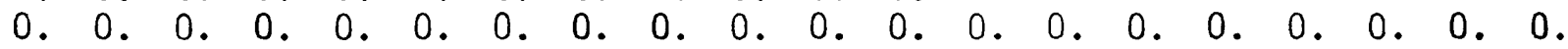

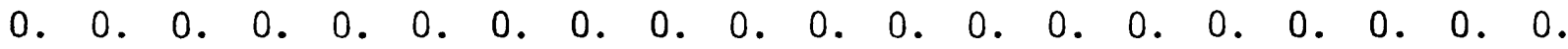

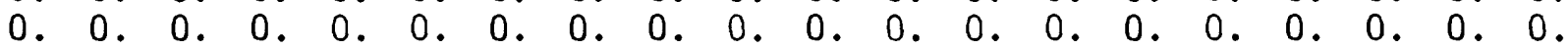

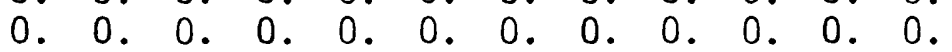

(BLANK LINE)

1.157E-05

1

(BLANK LINE)

(BLANK LINE)

(BLANK LINE)

(BLANK LINE)

(BLANK LINE)

(BLANK LINE)

193:

194:

195:

196:

197:

198:

199:

200:

(BLANK LINE)

(BLANK LINE)

(BLANK LINE)

(BLANK LINE)

(BLANK LINE)

$$
\text { 2. 2. 2. 2. } 2 \text {. }
$$

2. 2.100 .100 .100 .2 . 


\section{Line No.}

201: 10. 10. 10. 10. 10. 25. 50.100.100.100. 2 .

202: (BLANK LINE)

203: (BLANK LINE)

204:

205:

206:

207:

208:

209:

210:

211:

212:

213:

214:

215:

216:

217:

218:

219:

220:

221:

222:

223:

224:

225:

226:

227:

228:

229:

230:

231:

232:

233:

234:

235:

236:

237:

238:

239:

240:

241:

242:

243:

244:

245:

246:

247:

248:

249:

250:

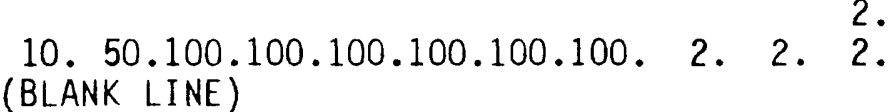

2. 10.10.10.10.10.10.10.10.10.

5. 5. 5. 5. 5. 5. 5. 5. 5. 5. 5. 5. 5. 5. 5. 5. 5. 5. 5. 5. 5. 5. 5. 5. 2. 2. 2. 2. 2. 2. 10. 10. 10. 10. 10. 10. 50.100.100.100.100.50.50. 2.

(BLANK LINE)

5. 10. 10. 10.10.10.10.10.10.10.10.10.10.10.10. 10. 10. 10.10.10.10.10.10.10.10.10.10.10.10.10.10.10.10.10. 10. 10. 50.100.100.50.50.50.50. 2.

(BLANK LINE)

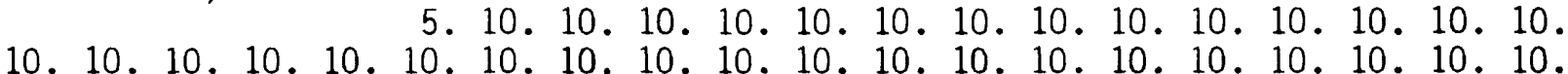
10. 50.100 .100 .50 .10 .10 .10 .2 .

5. 10. 10. 10.10.10.10.10. 5.

5. 10. 10. 10. 10. 10.10.10.10, 10.10.10,10.10.10.

10. 10. 10. 10. 10. 10.10.10.10, 10.10.10.10.10.10.10,10.10.10.10. 100.100 .100 .100 .50 .10 .10 .2 .2 .

5. 10. 10. 10. 10.10.10.10. 5 .

5. 10. 10. 10. 10.10.10.10.10.10.10.10.10.10.10.

10. 10. 10. 10. 10. 10. 10.10.10.10.10.10.10.10.10.10.10.10.10. 10. 100.100 .100 .2 .2 .10 .10 .2 .

5. 10. 10. 10. 10.10. 10.10. 5. 5.

10. 10. 10.10.10.10.10.10.10.10.

10. 10. 10. 10. 10. 50.50.50.50.50.50.50.50.50.50.100.100.100.100.100. 100.100. 10. 2. 2.2.2. 2. 2 .

5.100.100.100.100. 10. 10. 10. 10. 2. 2. 2 .

10. $10,10,10,10,50,50,50,50,50,50,50,50,50,50,100,100,100,100.100$. 100.100 .10 .2 .

$5.100 .100 .100 .100 .10 .10 .10 .10 \cdot 10.10 .2 .5 .5 .5 .5 .5$.

5. 5. 5. 5. 5. 5. 5. 5. 5. 5. 2. 2. 2. 2. 2. 2. 2. 2. 2. 2. 2. 10. 10. 10. 10.10.50.50.50.50.50.50.50.50.50.50.100.100.100.100.100. 100.100 .10 .2 .

5.100.100.100.100.100.100.10.10.10.10.10.10.10.10.10.10. 10. 10. 10. 10. 10. 10. 10. 10. 10. 10.10.10.10.10.10.10.10.10. 10. 10. 10. 10. 10. 10. 10.50.50.50.50.50.50.50.50.50.50.100.100.100.100.100. 100.100 .10 .2 .

5. 50. 50. 50.100.100.100.100.100.100.100.100.100.100.100.100.100. 100.100 .100 .100 .100 .100 .100 .100 .100 .100 .100 .100 .100 .100 .100 .100 .100 .100 .100 .100 . $100.100 .100 .100 .100 .100 .100 .100 .100 .100 .100 .100 .100 .100 .100 \cdot 100.100 .100 \cdot 100.100$. 100.100. 90. 40. 40. 40. 40 .

2. 50.50.50.100.100.100.100.100.100.100.100.100.100.100.100.100. $100.100 .100 \cdot 100.100 .100 .100 .100 .100 .100 .100 .100 .100 .100 .100 .100 .100 .100 .100 .100$. 100.100 .100 .100 .100 .100 .100 .100 .100 .100 .100 .100 .100 .100 .100 .100 .100 .100 .100 .100 . 100.100. 90. 80. 70.60.50.

2. 50.50.50.75.75.75.75.75.100.100.100.100.100.100.100.100. 


\section{Listing of input for the Farmington aquifer mode 1}

\section{Line No.}

251:

252:

253:

254:

255:

256:

257:

258:

259:

260:

261:

262:

263:

264:

265:

266:

267:

268:

269:

270:

271:

272:

273:

274:

275:

276:

277:

278:

279:

280:

281:

282:

283:

284:

285:

286:

287:

288:

289:

290:

291:

292:

293:

294:

295:

296:

297:

298:

299:

300:
$100.100 .100 .100 \cdot 100 \cdot 100 \cdot 100.100 \cdot 100.100 .100 .100 \cdot 100 \cdot 100 \cdot 100 \cdot 100 \cdot 100 \cdot 100 \cdot 100 \cdot 100$. $100.100 .100 .100 .100 .100 .100 .100 .100 .100 .100 .100 .100 \cdot 100.100 .100 .100 .100 .100 .100$. 50. 50.100 .100 .100 .100 .60 .

2. 50. 50. 50.75. 75. 75. 75. 75.100.100.100.100.100.100.100.100. $100.100 .100 .100 .100 .100 .100 .100 .100 .100 .100 .100 .100 .100 .100 .100 .100 \cdot 100 \cdot 100.100$. 100.100 .100 .100 .100 .100 .100 .100 .100 .100 .100 .100 .100 .100 .100 .100 .100 .100 .100 .100 . 50. 50.100.100.100.100.60.

2. 50. 50. 50.75.75.75.75. 75.100.100.100.100.100.100.100.100. 100.100 .100 .100 .100 .100 .100 .100 .100 .100 .100 .100 .100 .100 .100 .100 .100 .100 .100 .100 . 100.100 .100 .100 .100 .100 .100 .100 .100 .100 .100 .100 .100 .100 .100 .100 .100 .100 .100 .100 . 50. 50.100 .100 .100 .100 .60 .

2. 50. 50. 50.75.75.75.75. 75.100.100.100.100.100.100.100.100. $100.100 .100 .100 .100 .100 .100 .100 .100 .100 .100 .100 .100 \cdot 100 \cdot 100.100 .100 .100 .100 .100$. 100.100 .100 .100 .100 .100 .100 .100 .100 .100 .100 .100 .100 .100 .100 .100 .100 .100 .100 .100 . 50. 50.100 .100 .100 .100 .60 .

2. 50. 50. 50.75.75.75.75.75.100.100.100.100.100.100.100.100. 100.100 .100 .100 .100 .100 .100 .100 .100 .100 .100 .100 .100 .100 .100 .100 .100 .100 .100 .100 . 100.100 .100 .100 .100 .100 .100 .100 .100 .100 .100 .100 .100 .100 .100 .100 .100 .100 .100 .100 . 50. 50.100 .100 .100 .100 .60 .

2. 50. 50. 50.75.75.75.75.75.100.100.75.75.75.75.75.75. 100.100 .100 .100 .100 .100 .100 .100 .100 .100 .100 .100 .100 .100 .100 .100 .100 .100 .100 .100 . $100.100 .100 .100 .100 .100 .100 .100 .100 .100 .100 .100 \cdot 100 \cdot 100 \cdot 100.100 .100 .100 .100 .100$. 100.100 .100 .200 .100 .100 .70 .

2. 50. 50. 50.75.75.75.75.75.100.100.75.75.75.75.75.75. $100.100 .100 .100 \cdot 100.100 .100 .100 .100 .100 .100 .100 .100 .100 .100 .100 .100 .100 .100 .100$. 100.100 .100 .100 .100 .100 .100 .100 .100 .100 .100 .100 .100 .100 .100 .100 .100 .100 .100 .100 . 100.100 .100 .200 .100 .100 .70 .

2. 50. 50. 50.75.75.75.75. 75.100.100.75.75.75.75. 75. 75. $100.100 .100 .100 .100 .100 .100 .100 .100 .100 .100 .100 .100 .100 .100 .100 .100 \cdot 100 \cdot 100.100$. 100.100 .100 .100 .100 .100 .100 .100 .100 .100 .100 .100 .100 .100 .100 .100 .100 .100 .100 .100 . 100.100 .100 .200 .100 .100 .70 .

2. 50. 50. 50.75.75.75.75.75.100.100.75.75.75.75.75.75. 100.100 .100 .100 .100 .100 .100 .100 .100 .100 .100 .100 .100 .100 .100 .100 .100 .100 .100 .100 . $100.100 .100 .100 .100 .100 .100 .100 .100 .100 .100 .100 .100 .100 .100 \cdot 100.100 .100 .100 .100$. 100.100 .100 .200 .100 .100 .70 .

2. 50. 50. 50.75.75.75.75.75.100.100.75.75.75.75.75. 75. 100.100 .100 .100 .100 .100 .100 .100 .100 .100 .100 .100 .100 .100 .100 .100 .100 .100 .100 .100 . 100.100 .100 .100 .100 .100 .100 .100 .100 .100 .100 .100 .100 .100 .100 .100 .100 .100 .100 .100 . 100.100.100.200.100.100.70.

2. 10. 10. 10.75.75.75.75.75.75.75.75.75.75.75.75.75.

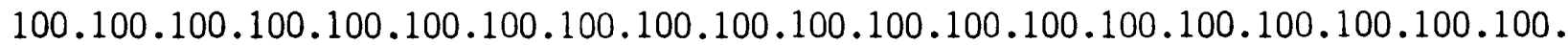
100.100 .100 .100 .100 .100 .100 .100 .100 .100 .100 .100 .100 .100 .100 .100 .100 .100 .100 .100 . 100.100 .100 .200 .100 .100 .70 .

2. 10. 10. 10.75. 75. 75. 75. 75. 75. 75. 75. 75. 75. 75. 75. 75. 100.100 .100 .100 .100 .100 .100 .100 .100 .100 .100 .100 .100 .100 .100 .100 .100 .100 .100 .100 . 100.100 .100 .100 .100 .100 .100 .100 .100 .100 .100 .100 .100 .100 .100 .100 .100 .100 .100 .100 . 100.100 .100 .200 .100 .100 .70 .

2. 10.10.10.75.75.75.75.75.75.75.75.75.75.75.75.75. 100.100 .100 .100 .100 .100 .100 .100 .100 .100 .100 .100 .100 .100 .100 .100 .100 .100 .100 .100 . 100.100 .100 .100 .100 .100 .100 .100 .100 .100 .100 .100 .100 .100 .100 .100 .100 .100 .100 .100 . 
Listing of input for the Farmington aquifer model

Line No.

301: $\quad 100.100 .100 .200 .100 .100 .70$.

302:

303:

304:

305:

306:

307:

308:

309:

310:

311:

312:

313:

314:

315:

316:

317:

318:

319:

320:

321:

322:

323:

324:

325:

326:

$327:$

328:

329:

330:

331:

332:

333:

334:

335:

336:

337:

338:

339:

340:

$341:$

342:

343:

$344:$

345:

346:

347 :

348:

349:

350:

2. 10. 10. 10.75.75.75.75.75.75.75.75.75.75.75. 75. 75. $100.100 .100 .100 .100 .100 .100 .100 .100 \cdot 100 \cdot 100.100 \cdot 100 \cdot 100 \cdot 100 \cdot 100 \cdot 100 \cdot 100 \cdot 100 \cdot 100$.

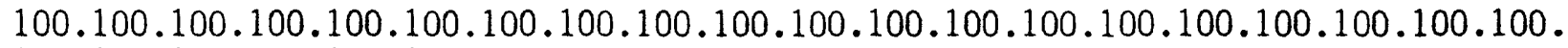
$100.100 .100 .200 \cdot 100 \cdot 100.70$.

2. $10.10,10.75 .75 .75 .75 .75 .75 .75,75.75,75.75 .75,75$. $100 \cdot 100 \cdot 100 \cdot 100 \cdot 100 \cdot 100 \cdot 100 \cdot 100 \cdot 100 \cdot 100 \cdot 100 \cdot 100 \cdot 100 \cdot 100 \cdot 100 \cdot 100 \cdot 100 \cdot 100 \cdot 100 \cdot 100$. 100.100 .100 .100 .100 .100 .100 .100 .100 .100 .100 .100 .100 .100 .100 .100 .100 .100 .100 .100 . 100.100 .100 .200 .100 .100 .70 .

2. 10. 10. 10. 50. 50. 50. 50. 50.50.75.75.75.75.75.75. 75. 75. 75. 75. 75. 75.100.100.100.100.100.100.100.100.100.100.50.50.50.50. 50 . 50.50 .50 .50 .50 .50 .50 .50 .50 .50 .50 .50 .50 .50 .50 .50 .50 .50 .50 .50$. $100.100 .100 \cdot 100 \cdot 100 \cdot 100.80$.

2. 2. 2. 2. 2. 2. 2. 2. 10.10.10.10.100.100.100.100.100. 100.100 .100 .100 .100 .100 .100 .100 .100 .100 .100 .100 .100 .100 .100 .50 .50 .50 .50 .50$. 50.50 .50 .50 .50 .50 .50 .50 .50 .50 .50 .50 .50 .50 .50 .50 .50 .50 .50 .50$. 50. $50.100 .100 \cdot 100.100 .80$.

100.100 .100 .100 .100 .100 .100 .100 .100 .100 .100 .10 . 10.100.100.100.100.100. $100.100 \cdot 100 \cdot 100 \cdot 100 \cdot 100 \cdot 100 \cdot 100.100 .100 \cdot 100 \cdot 100 \cdot 100 \cdot 100.100 .50 .50 .50 .50 .50$. $50.50 .50 .50 .50 .50 .50 .50 .50 .50 \cdot 50.50 .50 .50 .50 \cdot 50 \cdot 50.50 .50 .50$. 50. 50.100 .100 .100 .100 .80 .

$100.100 .100 .100 .100 .100 .100 .100 .100 .100 .100 .100 .10 \cdot 10 \cdot 10.100 \cdot 100 \cdot 100 \cdot 100.100$ $100.100 .100 .100 .100 .100 \cdot 100 \cdot 100 \cdot 100 \cdot 100 \cdot 100 \cdot 100 \cdot 100 \cdot 100 \cdot 100 \cdot 100 \cdot 100 \cdot 100 \cdot 100 \cdot 100$. 25. 25. 25. 25. 25. 25. 25. 25. 25. 25. 25.100 .100 .100 .100 .80 .

$100.100 .100 .100 .100 .100 \cdot 100 \cdot 100.100 \cdot 100 \cdot 100 \cdot 100 \cdot 100 \cdot 100 \cdot 100 \cdot 100 \cdot 100 \cdot 100 \cdot 100 \cdot 100$ $100.100 .100 .100 .100 .100 .100 .100 .100 \cdot 100.100 .100 \cdot 100.100 .100 .100 \cdot 100.100 \cdot 100.100$. $100.100 .100 \cdot 100 \cdot 100 \cdot 100.80$. 10. 10. 10. 10. 10. 10.10.10.10.10.10. 10. 10. 10.10.100.100.100.100.100. $100.100 .100 \cdot 100 \cdot 100 \cdot 100 \cdot 100 \cdot 100 \cdot 100 \cdot 100.100 .100 .100 .100 \cdot 100.100 \cdot 100 \cdot 100 \cdot 100 \cdot 100$. 100.100 .100 .100 .100 .100 .80 .

$10 \cdot 10 \cdot 10.10 \cdot 10.10 \cdot 10 \cdot 10 \cdot 10.2 .10 .10 .10$. 10. 10. 10. 10. 10. 10. 10. 10. 10. 10. 10. 10. 10. 10. 10.10.10.10.10.10. 10. 10. 10. 10. 10.10.10.10.10.10.10.10.10.10.10.10.10.10.10.10. 10.100 .100 .100 .100 .100 .80 .

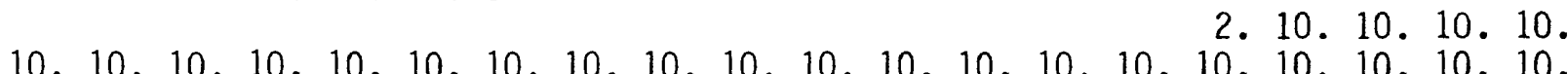

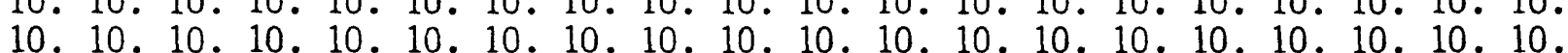
10. 10. 10. 10.10.10. 5 .

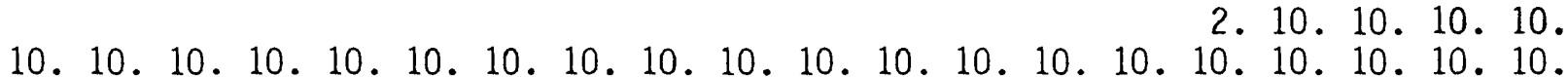
10. 10. 10.10.10.10.10.10.10.10.10.10.10.10.10.1.1. 1. 1. 1. 1. 1.1 .1 .1 .1 .1 .

1. 1. 1. 1. 1. 1. 1. 1. 1. 1. 1. 1. 1. 1. 2. 10. 10. 10. 10. 2. 2. 2. 2. 2. 1. 1. 1. 1. 1. 1. 1. 1. 1. 1. 1. 1. 1. 1. 1. (BLANK LINE) (BLANK LINE) 
Listing of input for the Farmington aquifer model

\section{Line No.}

351:

352:

353:

354:

355:

356:

357:

358:

359:

360:

$361:$

362:

363:

364:

365:

366:

$367:$

368:

369:

370:

371:

372:

373:

374:

375:

376:

377:

378:

379:

380:

381:

382:

383:

384:

385:

386:

387:

388:

389:

390:

391:

392:

393:

394:

395:

396:

397:

398:

399:

400:
(BLANK LINE)

(BLANK LINE)

(BLANK LINE)

.9

(BLANK LINE)

(BLANK LINE)

(BLANK LINE)

(BLANK LINE)

(BLANK LINE)

(BLANK LINE)

(BLANK LINE)

(BLANK LINE)

(BLANK LINE)

(BLANK LINE)

(BLANK LINE)

(BLANK LINE)
1

410.320 .310 .240 .210

300.260 .215 .220 .200 .190 .

220.240 .200 .210 .210 .190 .210 .190 .195 .210 .200 .

200.200 .200 .200 .200 .200 .200 .200 .200 .200

(BLANK LINE)

(BLANK LINE)

190.190 .190 .180 .180 .180 .180 .185 .230 .230 .230 .

210.210 .210 .210 .210 .200 .200 .200 .200 .200 (BLANK LINE)

$320.320 .310 \cdot 310.300 .300 .290 .280 .270 .260 .250 .240 .230 .220 .210 .200 .200 \cdot 200 \cdot 200.200$. 190.180 .170 .160 .160 .175 .185 .185 .220 .

(BLANK LINE) $330.330 .330 \cdot 330 \cdot 330 \cdot 320 \cdot 320 \cdot 320 \cdot 320 \cdot 320.230 .230 .230 \cdot 230 \cdot 230 \cdot 220 \cdot 220 \cdot 220 \cdot 220 \cdot 220$. 180.170 .160 .145 .170 .195 .195 .195 .210$.

(BLANK LINE)

$280.280 .280 .280 \cdot 280 \cdot 330 \cdot 330.330 \cdot 330 \cdot 330 \cdot 310 \cdot 310 \cdot 310 \cdot 310 \cdot 310$. $310.310 .310 \cdot 310 \cdot 310.250 .250 .250 \cdot 250.250 .230 .230 .230 .230 .230 \cdot 220.220 .220 \cdot 220.220$. 180.160 .160 .157 .160 .205 .200 .215 .220 . 220.220 .235 .275 .275 .270 .240 .250 .260 .

$290.290 .290 .290 .290 \cdot 310 \cdot 310.310 \cdot 310 \cdot 310 \cdot 310 \cdot 310 \cdot 310 \cdot 310 \cdot 310$. $260.260 .260 .260 .260 .230 .230 .230 .230 .230 .230 .230 .230 .230 .230 \cdot 190.190 \cdot 190 \cdot 190.190$. 160.150 .145 .166 .205 .215 .215 .240 .240 . 200.215 .225 .230 .230 .230 .230 .230 .260 .

$310 \cdot 310 \cdot 310 \cdot 310 \cdot 310 \cdot 310 \cdot 310 \cdot 310 \cdot 310 \cdot 310 \cdot 310 \cdot 310 \cdot 310 \cdot 310 \cdot 260$. $250.250 .250 .250 .250 .230 .230 .230 .230 .230 .190 .190 .190 \cdot 190.190 \cdot 170.170 \cdot 170 \cdot 170.170$. 160.165 .164 .185 .215 .215 .215 .265 .

180.200 .210 .210 .220 .220 .220 .220 .210 .230 .

290.290 .290 .290 .290 .260 .260 .260 .260 .260 .

$240.240 .240 .240 .240 .170 .170 \cdot 170.170 .170 .160 .160 .160 \cdot 160.160 \cdot 190.190 .190 .190 .190$. 170.140 .185 .230 .230 .230 .230 .230 .

170.170 .170 .190 .190 .200 .200 .205 .205 .210 .220 .235 .

235.235 .235 .235 .235 
Listing of input for the Farmington aquifer model

\section{Line No.}

401: $\quad 220.220 .220 .220 .220 .160 .160 .160 .160 .160 .160 .160 .160 .160 .160 .137 .137 .137 .137 .137$. 402: $\quad 150.170 .185 .200$.

403:

404:

405:

406:

407:

408:

409:

410:

411:

412:

413:

414:

415:

416:

417:

418:

419:

420:

421:

422:

423:

424:

425:

426:

427:

428:

429:

430:

431:

432:

433:

434:

435:

436:

437:

438:

439:

440:

441:

442:

443:

444:

445:

446:

447:

448:

449:

450:

$160.160 .110 .160 .170 \cdot 180.180 \cdot 180 \cdot 195.200 \cdot 200 \cdot 210.210 \cdot 210 \cdot 210 \cdot 210 \cdot 210$. $210.210 .210 .210 .210 .180 .180 .180 .180 .180 .220 .220 .220 .220 .220 .220 .220 .220 .220 \cdot 170$. 160.160 .160 .160 .160 .150 .150 .150 .150 .150 .130 .130 .130 .130 .130 .135 .135 .135 .135 .135 . 168.175 .210 .200 .

160.110 .110 .135 .160 .170 .180 .185 .185 .185 .185 .180 .190 .190 .190 .190 .190$. $190.190 .190 .190 .190 .190 .190 .190 .190 .190 .190 .190 .190 \cdot 190 \cdot 190.190 .190 .190 .190 .190$. 190.190 .190 .190 .190 .165 .165 .165 .165 .165 .128 .128 .128 .128 .128 .150 .150 .150 .150 .150 . 170.180 .160 .230 .

$160.130 .140 .155 \cdot 160 \cdot 165 \cdot 165 \cdot 170 \cdot 170.150 \cdot 150 \cdot 170.170 \cdot 170 \cdot 170 \cdot 170.170$. $170.170 .170 .170 .170 .170 .170 .170 .170 .170 .170 .170 .170 .170 \cdot 170.165 .165 .165 .165 .165$. 155.155 .155 .155 .155 .125 .125 .125 .125 .125 .136 .136 .136 .136 .136 .160 .160 .160 .160 .160 . 175.180 .160 .210 .210 .210 .190 .

137.139 .140 .140 .140 .150 .143 .140 .140 .140 .141 .143 .133 .133 .133 .133 .133$. 133.133 .133 .133 .133 .135 .135 .135 .135 .135 .125 .125 .125 .125 .125 .145 .145 .145 .145 .145 . 145.145 .145 .145 .145 .145 .145 .145 .145 .145 .155 .155 .155 .155 .155 .170 .170 .170 .170 .170 . 175.185 .160 .210 .200 .190 .190 .

140.136 .139 .140 .150 .150 .132 .130 .140 .140 .140 .130 .130 .130 .130 .130 .130 . 120.120 .120 .120 .120 .120 .120 .120 .120 .120 .125 .125 .125 .125 .125 .80 .80 .80 .80 .80 . 85. 85. 85. 85. 85.128.128.128.128.128.145.145.145.145.145.160.160.160.160.160. 170.190 .200 .200 .210 .190 .190 .

140.136 .139 .140 .150 .150 .132 .130 .140 .140 .140 .130 .130 .130 .130 .130 .130$. 120.120 .120 .120 .120 .120 .120 .120 .120 .120 .125 .125 .125 .125 .125 .80 .80 .80 .80 .80 .

85. 85. 85. 85. 85.128.128.128.128.128.145.145.145.145.145.160.160.160.160.160. 170.190 .200 .200 .160 .190 .190 .

140.136 .139 .140 .150 .150 .132 .130 .140 .140 .140 .130 .130 .130 .130 .130 .130 . 120.120 .120 .120 .120 .120 .120 .120 .120 .120 .125 .125 .125 .125 .125 .80 .80 .80 .80 .80 . 85. 85. 85. 85. 85.128.128.128.128.128.145.145.145.145.145.160.160.160.160.160. 170.190 .200 .200 .210 .190 .190 .

140.136 .139 .140 .150 .150 .132 .130 .140 .140 .140 .130 .130 .130 .130 .130 .130$. 120.120 .120 .120 .120 .120 .120 .120 .120 .120 .125 .125 .125 .125 .125 . 80.80.80.80.80. 85. 85. 85. 85. 85.128.128.128.128.128.145.145.145.145.145.160.160.160.160.160. 170.190 .200 .200 .160 .190 .190 .

$140.136 .139 .140 .150 .150 .132 .130 .140 .140 .140 .130 .130 .130 \cdot 130.130 .130$. 120.120 .120 .120 .120 .120 .120 .120 .120 .120 .125 .125 .125 .125 .125 . 80. 80. 80. 80. 80 . 85. 85. 85. 85. 85.128.128.128.128.128.145.145.145.145.145.160.160.160.160.160. 170.190 .200 .200 .160 .190 .190 .

140.136 .135 .135 .134 .133 .131 .130 .130 .130 .128 .128 .130 .130 .130 .130 .130$. $120.120 .120 .120 .120 .80 .80 .80 .80 .80 .82 \cdot 82.82 .82 .82 .83 .83 .83 .83 .83$. 124.124 .124 .124 .124 .125 .125 .125 .125 .125 .130 .130 .130 .130 .130 .150 .150 .150 .150 .150 . 150.180 .180 .180 .190 .190 .190 .

140.136 .135 .135 .134 .133 .131 .130 .130 .130 .128 .128 .130 .130 .130 .130 .130$. 120.120 .120 .120 .120 .80 .80 .80 .80 .80 .82 .82 .82 .82 .82 .83 .83 .83 .83 .83$. $124.124 .124 .124 .124 .125 .125 .125 .125 .125 .130 .130 .130 \cdot 130.130 .150 .150 .150 .150 .150$. 150.180 .180 .180 .190 .190 .190 .

140.136 .135 .135 .134 .133 .131 .130 .130 .130 .128 .128 .130 .130 .130 .130 .130$. $120.120 .120 .120 .120 .80 .80,80.80 .80,82.82 .82 .82 .82 .83 .83 .83 .83 .83$. 124.124 .124 .124 .124 .125 .125 .125 .125 .125 .130 .130 .130 .130 .130 .150 .150 .150 .150 .150 . 150.180 .180 .180 .190 .190 .190 . 
Listing of input for the Farmington aquifer model

Line No.

451:

452:

453:

454:

455:

456:

457:

458:

459:

460:

461:

462:

463:

464:

465:

466:

467:

468:

469:

470:

471:

472:

473:

474:

475:

476:

477:

478:

479:

480:

481:

482:

483:

484:

485:

486:

487:

488:

489:

490:

491:

492:

493:

494:

495:

496:

497:

498:

499:

500:

140.136 .135 .135 .134 .133 .131 .130 .130 .130 .128 .128 .130 .130 .130 .130 .130$. 120.120 .120 .120 .120 .80 .80 .80 .80 .80 .82 .82 .82 .82 .82 .83 .83 .83 .83 .83 . 124.124 .124 .124 .124 .125 .125 .125 .125 .125 .130 .130 .130 .130 .130 .150 .150 .150 .150 .150 . 150.180 .180 .180 .190 .190 .190 .

140.136 .135 .135 .134 .133 .131 .130 .130 .130 .128 .128 .130 .130 .130 .130 .130$. $120.120 .120 .120 .120 .80 .80 .80,80,80.82 .82 .82 .82 .82 .83 .83 .83 .83 .83$. $124.124 .124 .124 .124 .125 .125 .125 .125 .125 .130 .130 .130 .130 .130 .150 .150 .150 \cdot 150.150$. 150.180 .180 .180 .190 .190 .190 .

170.155 .155 .155 .150 .147 .145 .150 .130 .130 .132 .128 .131 .131 .131 .131 .131$. 140.140 .140 .140 .140 .134 .134 .134 .134 .134 .134 .134 .134 .134 .134 .134 .134 .134 .134 .134 . 135.135 .135 .135 .135 .137 .137 .137 .137 .137 .140 .140 .140 .140 .140 .155 .155 .155 .155 .155 . 155.170 .180 .180 .190 .190 .190 .

150.155 .155 .155 .150 .147 .145 .150 .130 .130 .132 .128 .131 .131 .131 .131 .131$. 140.140 .140 .140 .140 .134 .134 .134 .134 .134 .134 .134 .134 .134 .134 .134 .134 .134 .134 .134 . 135.135 .135 .135 .135 .137 .137 .137 .137 .137 .140 .140 .140 .140 .140 .155 .155 .155 .155 .155 . 155.170 .180 .180 .190 .190 .190$.

150.155 .155 .155 .150 .147 .145 .150 .130 .130 .132 .128 .131 .131 .131 .131 .131$. 120.120 .120 .120 .120 .134 .134 .134 .134 .134 .134 .134 .134 .134 .134 .134 .134 .134 .134 .134 . 135.135 .135 .135 .135 .137 .137 .137 .137 .137 .140 .140 .140 .140 .140 .155 .155 .155 .155 .155 . 155.170 .180 .180 .190 .190 .190 .

150.155 .155 .155 .150 .147 .145 .150 .130 .130 .132 .128 .131 .131 .131 .131 .131$. 140.140 .140 .140 .140 .134 .134 .134 .134 .134 .134 .134 .134 .134 .134 .134 .134 .134 .134 .134 . 135.135 .135 .135 .135 .137 .137 .137 .137 .137 .140 .140 .140 .140 .140 .155 .155 .155 .155 .155 . 155.170 .180 .180 .190 .190 .190 .

150.155 .155 .155 .150 .147 .145 .150 .130 .130 .132 .128 .131 .131 .131 .131 .131$. 140.140 .140 .140 .140 .134 .134 .134 .134 .134 .134 .134 .134 .134 .134 .134 .134 .134 .134 .134 . 135.135 .135 .135 .135 .137 .137 .137 .137 .137 .140 .140 .140 .140 .140 .155 .155 .155 .155 .155 . 155.170.180.180.190.190.190.

210.190 .190 .190 .190 .165 .160 .170 .145 .150 .131 .128 .132 .132 .132 .132 .132 . 130.130 .130 .130 .130 .140 .140 .140 .140 .140 .140 .140 .140 .140 .140 .143 .143 .143 .143 .143 . 145.145 .145 .145 .145 .147 .147 .147 .147 .147 .150 .150 .150 .150 .150 .165 .165 .165 .165 .165 . $180.150 .160 .180 \cdot 180.170 .160$.

$320.300 .320 .300 \cdot 280.270 .250 .220 .150 .150 .149 .138 .128 \cdot 128.128 \cdot 128.128$. 129.129.129.129.129. 78. 78. 78. 78. 78.118.118.118.118.118.130.130.130.130.130. 143.143 .143 .143 .143 .145 .145 .145 .145 .145 .150 .150 .150 .150 .150 .155 .155 .155 .155 .155 . 160.150 .150 .150 .150 .165 .150 .

134.134 .134 .134 .134 .125 .125 .125 .125 .125 .117 .117 .117 .117 .117 .120 .120 .120 .120 .120 . 120.120 .120 .120 .120 .124 .124 .124 .124 .124 .128 .128 .128 .128 .128 .133 .133 .133 .133 .133 . 135.160 .160 .165 .140 .140 .140 .

$270.200 .190 .190 \cdot 190 \cdot 170.160 .150 .130 .150$. 145.145 .145 .145 .145 .115 .115 .115 .115 .115 .125 .125 .125 .125 .125 .125 .125 .125 .125 .125 . $117.117 .117 .117 .117 .120 .120 .120 .120 .120 .120 \cdot 120.120 \cdot 120.120 .120 .120 \cdot 120.120 .120$. 125.134 .139 .138 .138 .150 .150 .

$270.250 .260 .260 .210 \cdot 180.180 .180 .180 .180$ 160.160 .160 .160 .160 .125 .125 .125 .125 .125 .135 .135 .135 .135 .135 .135 .135 .135 .135 .135 . $127.127 .127 .127 .127 .135 .135 .135 .135 .135 .126 .126 .126 \cdot 126.126 .127 .127 \cdot 127.127 .127$. 125.126 .135 .138 .140 .149 .148 .

$270.210 .180 .180 \cdot 180 \cdot 180.180$. $180.180 .180 .180 \cdot 180.170 \cdot 170.170 .170 .170 .155 \cdot 155 \cdot 155 \cdot 155.155 .150 .150 \cdot 150 \cdot 150 \cdot 150$. 
Listing of input for the Farmington aquifer model

Line No.

501: $\quad 145.145 .145 .145 .145 .145 .145 .145 .145 .145 .135 .135 .135 .135 .135 .135 .135 .135 .135 .135$. 502: $\quad 135.135 .135 .127 .125 .125 .125$.

503:

504:

505:

506:

507:

508:

509:

510:

511:

512:

513:

514:

515:

516:

517:

518:

519:

520:

521:

522:

523:

524:

525:

526:

527:

528:

529:

530:

531:

532:

533:

534:

535:

536:

537:

538:

539:

540:

541:

542:

543:

544:

545:

546:

547:

548:

549:

550:

210.210 .210 .210 .210 .180 .180 .180 .180 .180 .180 .180 .180 .180 .180 .180 .180 .180 .180 .180 . 167.167 .167 .167 .167 .167 .167 .167 .167 .167 .167 .167 .167 .167 .167 .160 .160 .160 .160 .160 . 160.160 .145 .145 .135 .155 .155 .

235.235 .235 .235 .235 $235.235 .235 .235 .235 .180 .180 .180 .180 .180 .180 .180 .180 \cdot 180 \cdot 180.190 .190 \cdot 190.190 .190$. 240.240 .240 .240 .240 .210 .210 .210 .210 .210 .220 .220 .220 .220 .220 .210 .210 .210 .210 .210 . 210.160 .160 .150 .150 .150 .210 .

260.260 .260 .260 .260 . $310.260 .260 .260 .260 .260 .260 .260 .260 .250 .250 .250 .250 \cdot 250 \cdot 250 \cdot 275.275 \cdot 275.240 .230$. $230.230 .230 .230 .230 .230 .230 .230 .230 .230 .220 .220 .220 .220 .220 .250 .250 \cdot 250.250 .250$. 280.260 .260 .260 .260 .250 .260 .

$310 \cdot 310 \cdot 310 \cdot 310 \cdot 310$. $360 \cdot 360 \cdot 360 \cdot 360 \cdot 360 \cdot 410 \cdot 410 \cdot 410 \cdot 410 \cdot 410 \cdot 435.435 .420 \cdot 410 \cdot 380 \cdot 360 \cdot 360 \cdot 340 \cdot 330 \cdot 320$. 280.280 .280 .280 .280 .290 .290 .290 .290 .290 .270 .270 .270 .270 .270 .300 .300 .300 .300 .300 . (BLANK LINE)

(BLANK LINE)

(BLANK LINE)

(BLANK LINE)

(BLANK LINE)

$$
0.0
$$

1. 157E-05

(BLANK LINE)

(BLANK LINE)

(BLANK LINE)

(BLANK LINE)

(BLANK LINE)

(BLANK LINE)

(BLANK LINE)

(BLANK LINE)

(BLANK LINE)

(BLANK LINE)

(BLANK LINE)

(BLANK LINE)

(BLANK LINE)

(BLANK LINE)

(BLANK LINE)

(BLANK LINE)

1. 1.1 . 1 .

(BLANK LINE)

(BLANK LINE)

(BLANK LINE)

1. 1.1 .

(BLANK LINE)

(BLANK LINE)

(BLANK LINE)

1. 1.1 .

(BLANK LINE) 


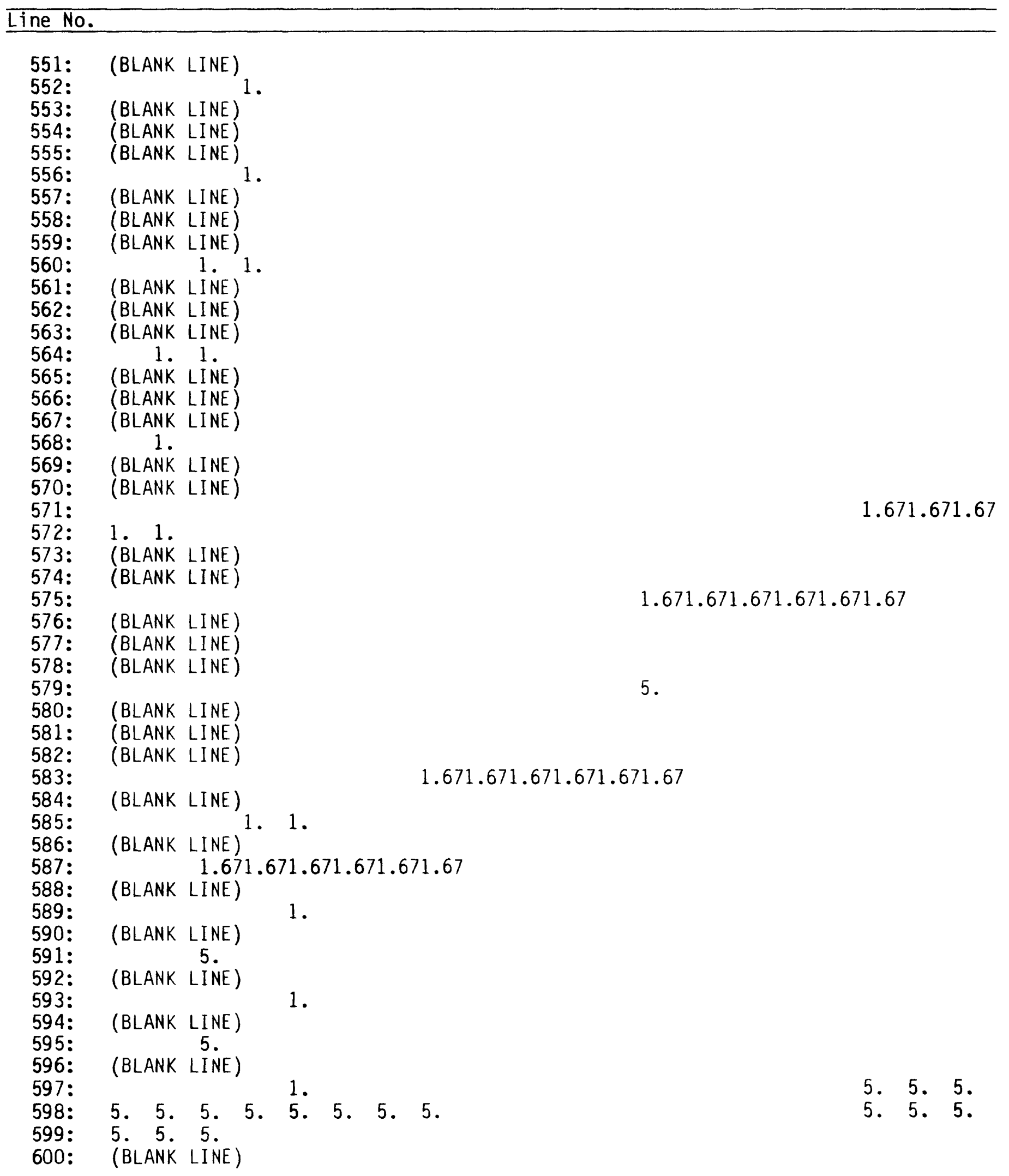




\section{Line No.}

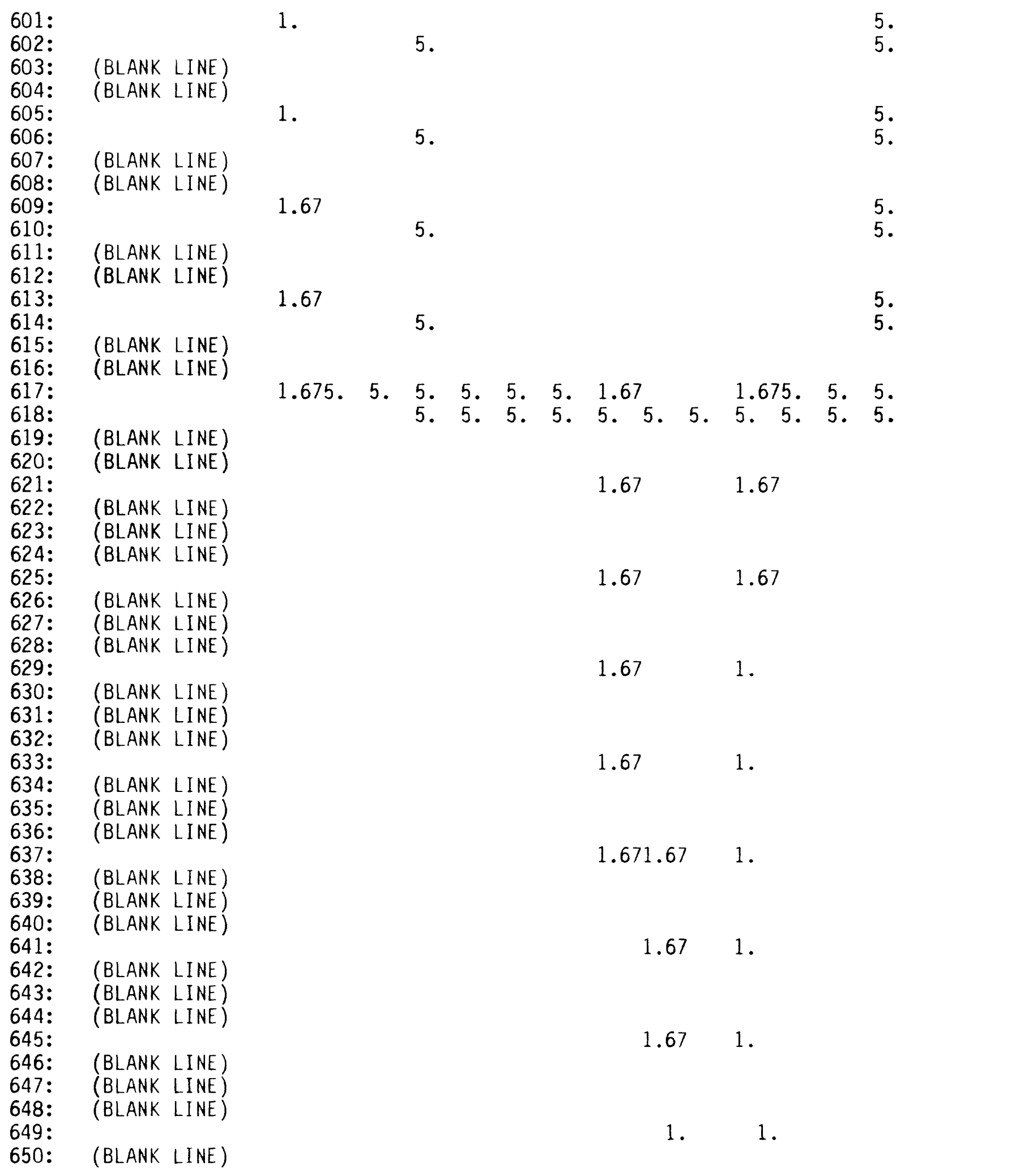


Listing of input for the Farmington aquifer model

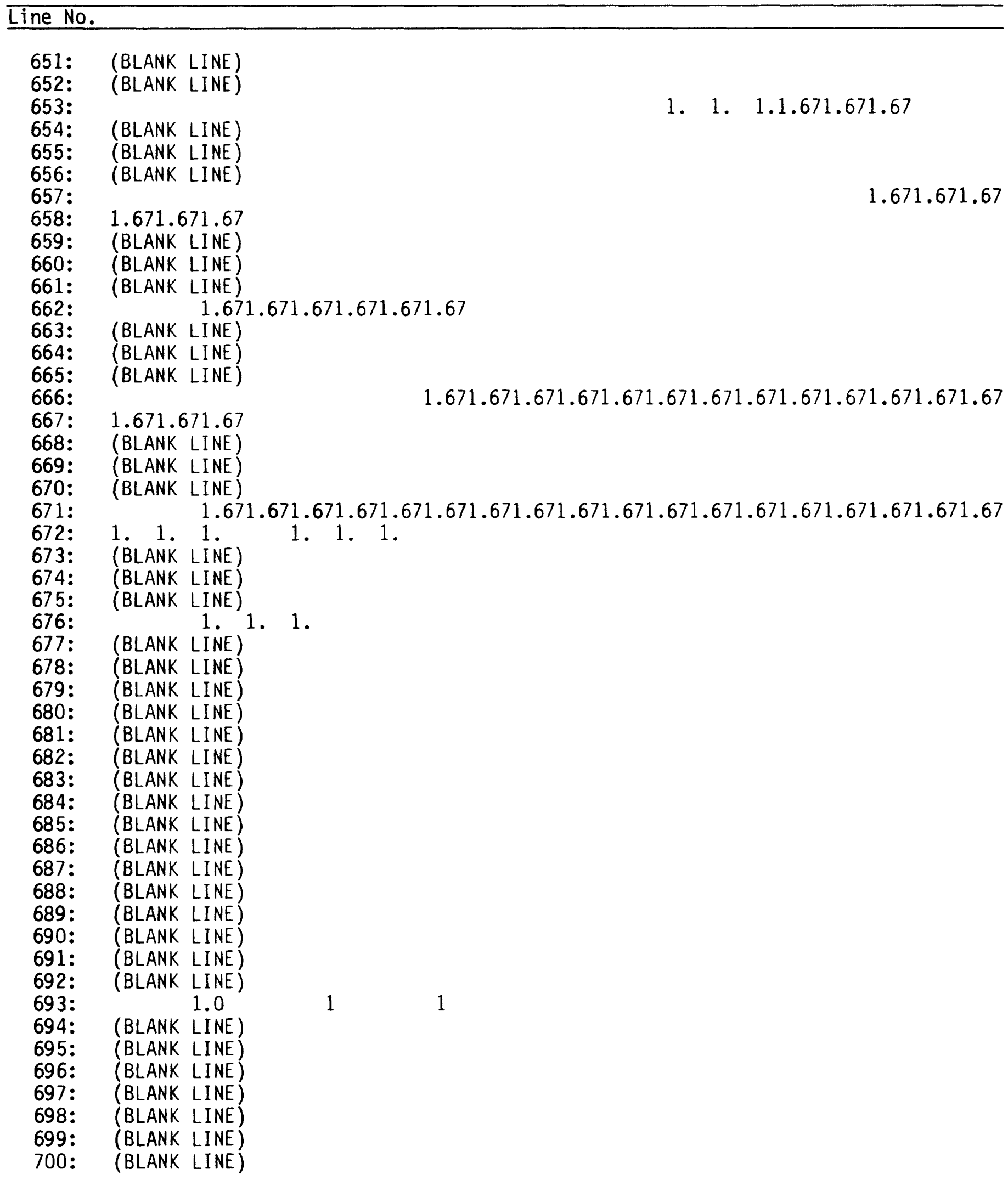


Line No.

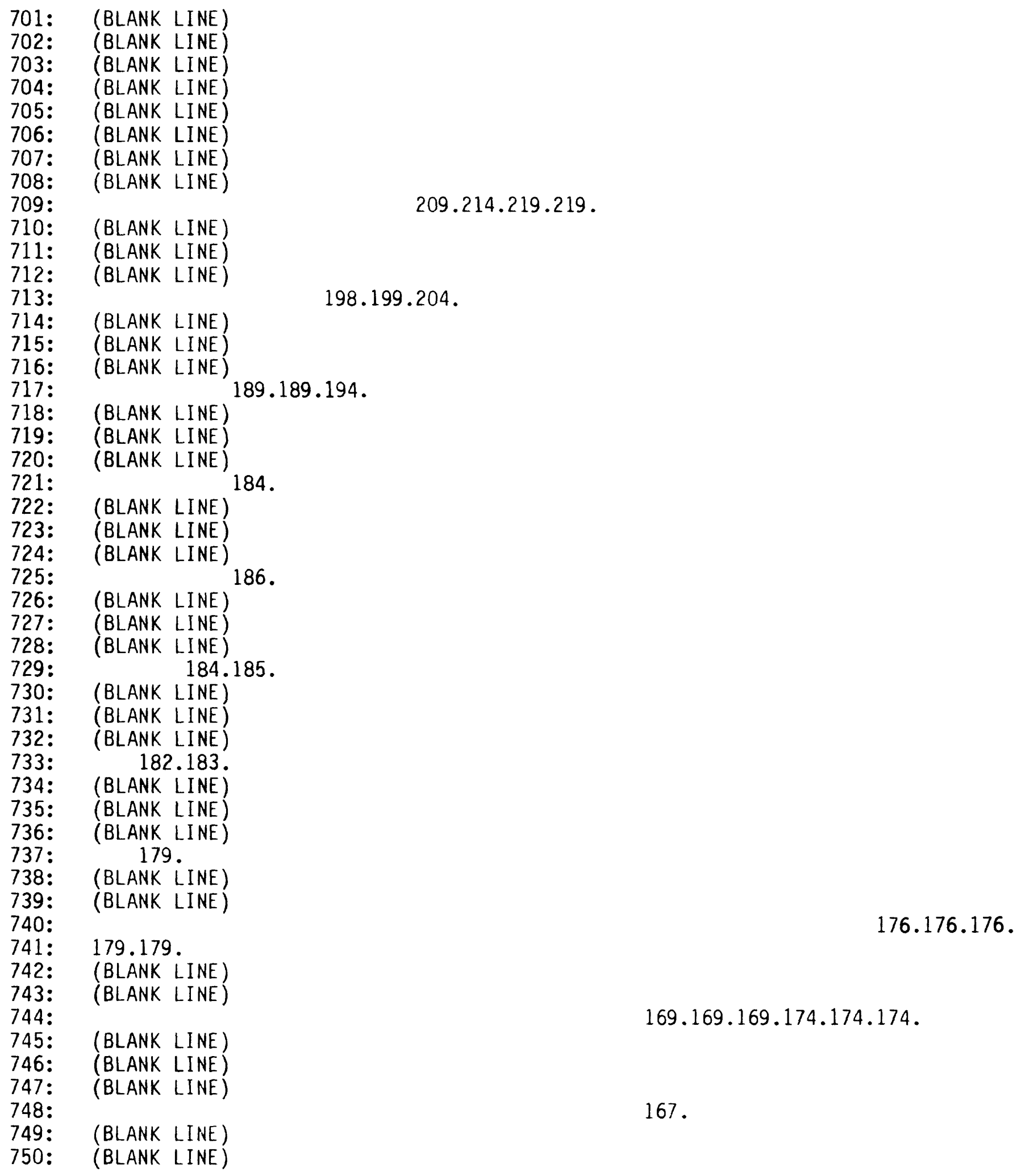


Listing of input for the Farmington aquifer model

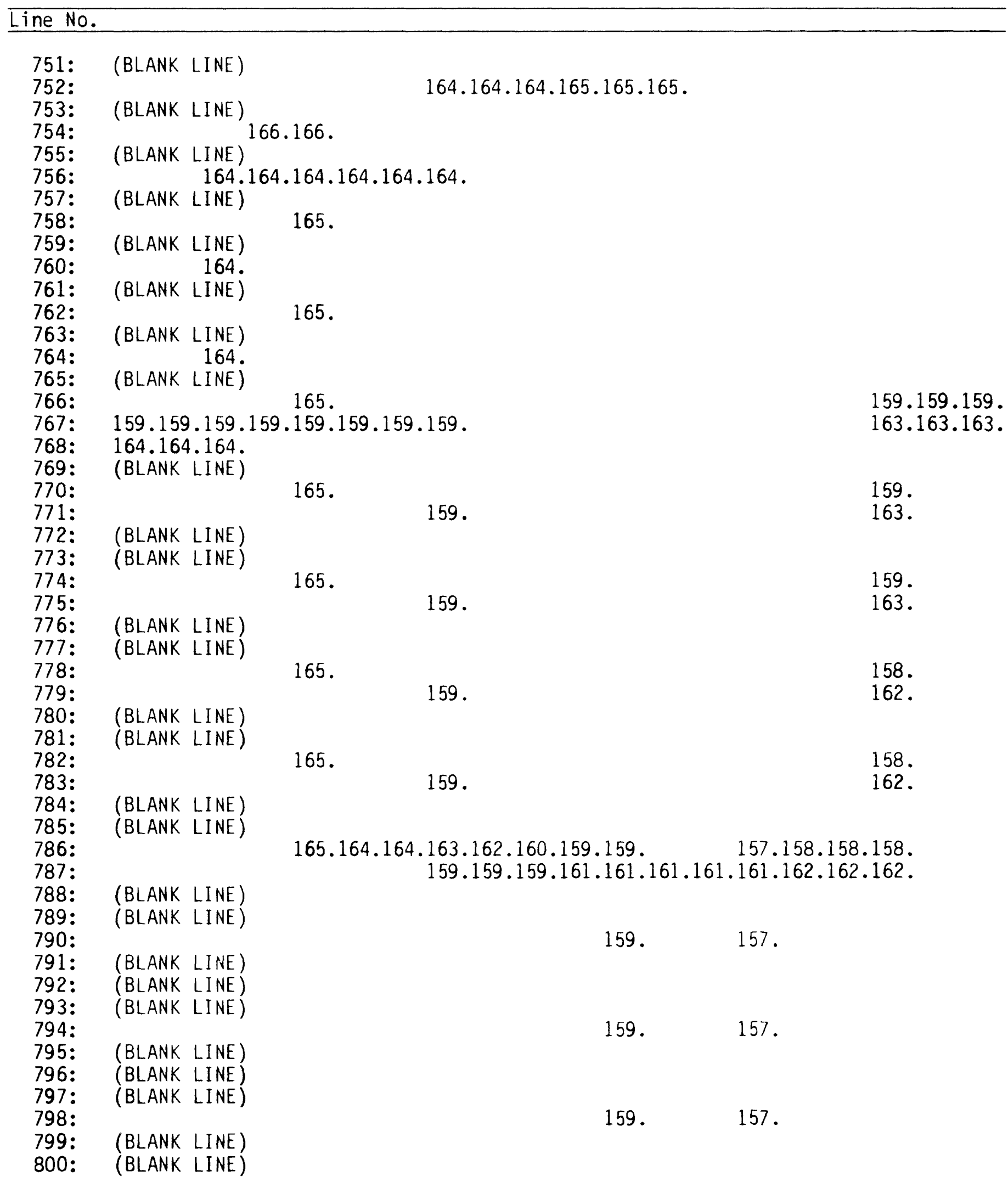


Listing of input for the Farmington aquifer mode 1

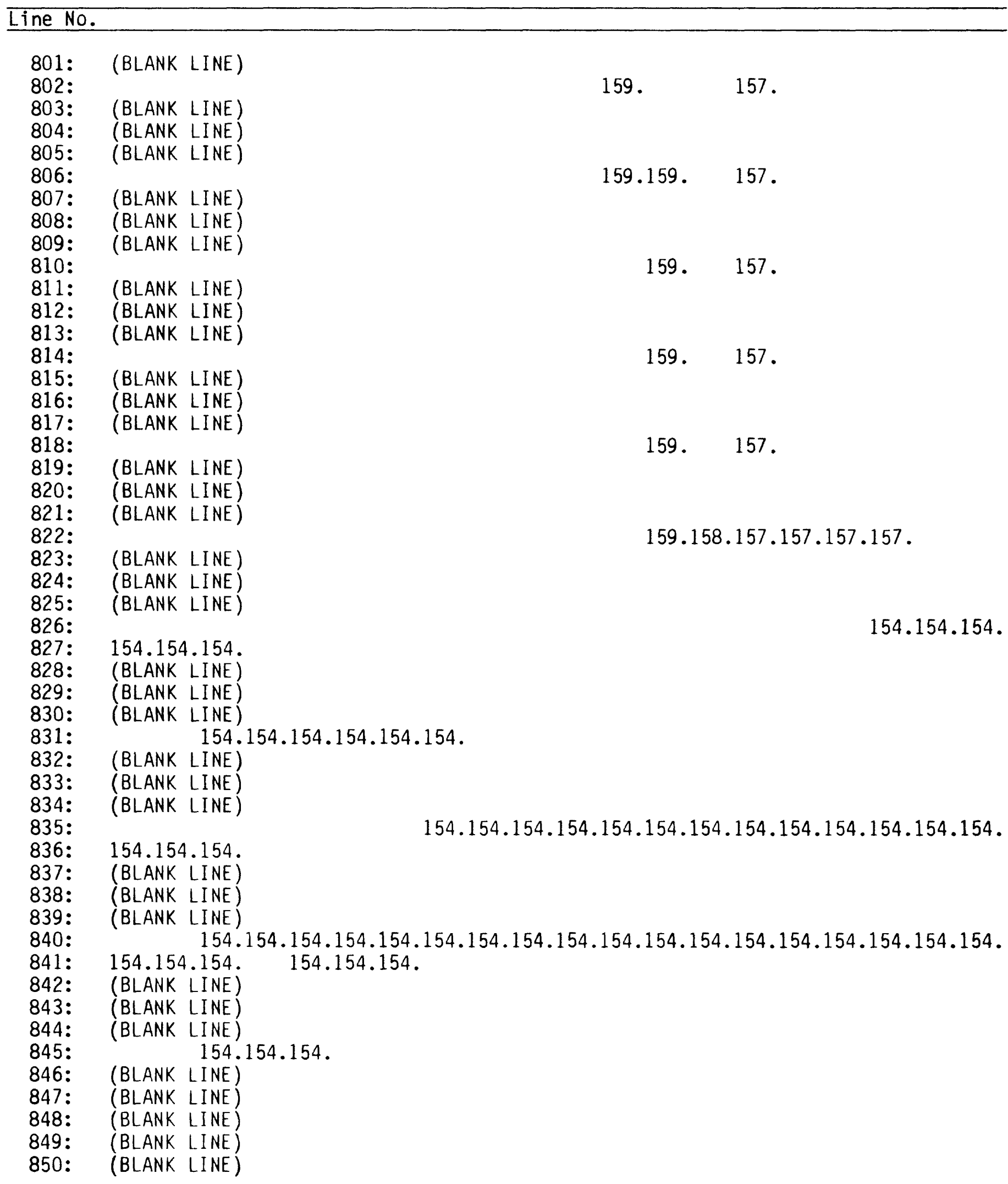




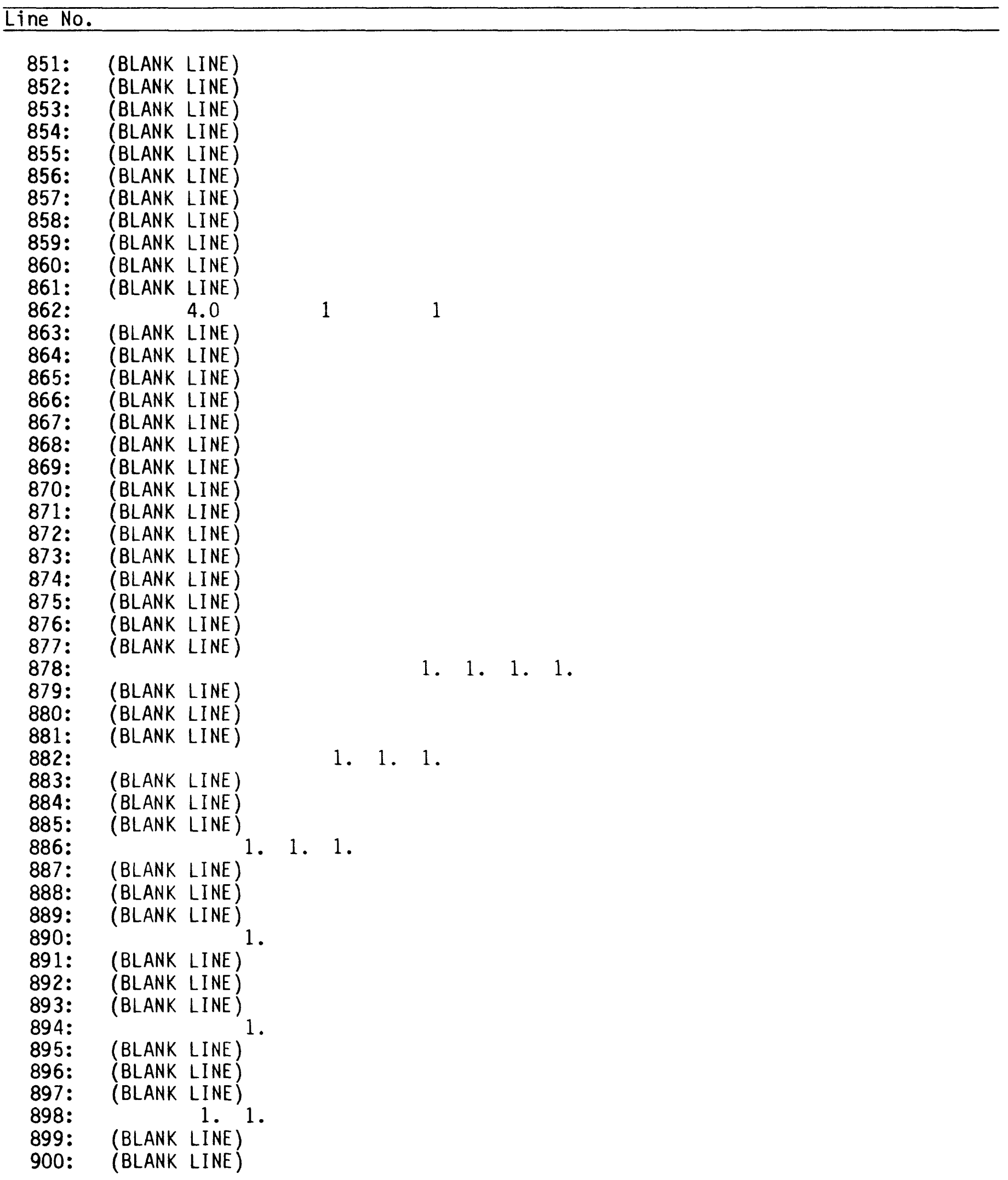




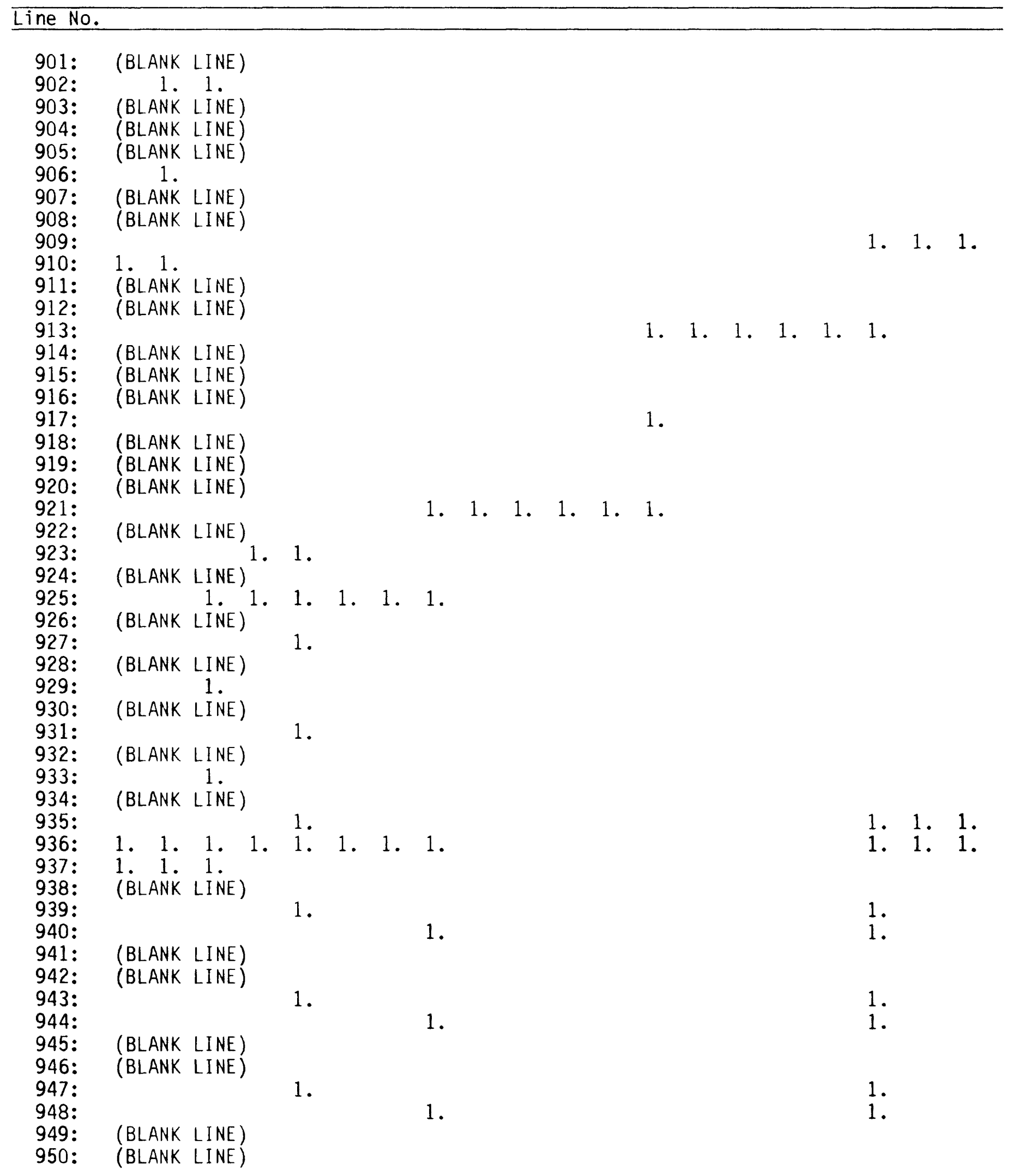




\section{Line No.}

951:

952:

953:

954:

955:

956:

957:

958:

959:

960:

961:

962:

963:

964:

965:

966:

967:

968:

969:

970:

971:

972:

973:

974:

975:

976:

977:

978:

979:

980:

981:

982:

983:

984:

985:

986:

987:

988:

989:

990:

991:

992:

993:

994:

995:

996:

997:

998:

999:

1000:
1.

(BLANK LINE)

(BLANK LINE)

(BLANK LINE)

(BLANK LINE)

(BLANK LINE)

(BLANK LINE)

(BLANK LINE)

(BLANK LINE)

(BLANK LINE)

(BLANK LINE)

(BLANK LINE)

(BLANK LINE)

(BLANK LINE)

(BLANK LINE)

(BLANK LINE)

(BLANK LINE)

(BLANK LINE)

(BLANK LINE)

(BLANK LINE)

(BLANK LINE)

(BLANK LINE)

(BLANK LINE)

(BLANK LINE)

(BLANK LINE)

(BLANK LINE)

(BLANK LINE)

(BLANK LINE)

(BLANK LINE)

(BLANK LINE)

(BLANK LINE)

(BLANK LINE)

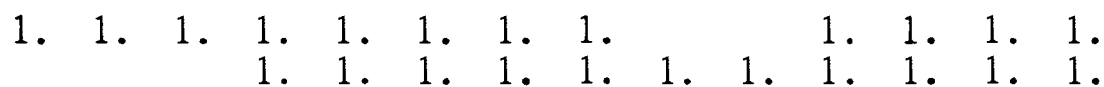

1.

1.

1.
1.

1 . 1 .

1. 1 .

1. 1.1 .

1. 1 .

1.

1. 1 .

1. 1. 1. 1. 1. 1 .

1. 1.1 .

1. 1.1 .

(BLANK LINE)

(BLANK LINE)

(BLANK LINE)

1. 1. 1. 1. 1. 1 . 


\section{Listing of input for the Farmington aquifer model}

\section{Line No.}

$\begin{array}{ll}\text { 1001: } & \text { (BLANK LINE) } \\ \text { 1002: } & \text { (BLANK LINE) } \\ \text { 1003: } & \text { (BLANK LINE) }\end{array}$

1004:

1005:

1006:

1007:

1008:

1009:

1010:

1011:

1012:

1013:

1014:

1015:

1016:

1017:

1018:

1019:

1020:

1021:

1022:

1023:

1024:

1025:

1026:

1027:

1028:

1029:

1030:

1031:

1032:

1033:

1034:

1035:

1036:

1037:

1038:

1039:

1040:

1041:

1042:

1043:

1044:

1045:

1046:

1047:

1048:

1049:

1050:

1. 1.1 .

(BLANK LINE)

(BLANK LINE)

(BLANK LINE)

(BLANK LINE)

(BLANK LINE)

(BLANK LINE)

(BLANK LINE)

(BLANK LINE)

(BLANK LINE)

(BLANK LINE)

(BLANK LINE)

(BLANK LINE)

(BLANK LINE)

(BLANK LINE)

(BLANK LINE)

(BLANK LINE)

(BLANK LINE)

(BLANK LINE)

(BLANK LINE)

(BLANK LINE)

(BLANK LINE)

(BLANK LINE)

(BLANK LINE)

(BLANK LINE)

(BLANK LINE)

(BLANK LINE)

(BLANK LINE)

(BLANK LINE)

(BLANK LINE)

(BLANK LINE)

(BLANK LINE)

(BLANK LINE)

(BLANK LINE)

(BLANK LINE)

(BLANK LINE)
1. 1. 1. 1. 1. 1. 1. 1. 1. 1. 1. 1. 1.

1. 1. 1. 1. 1. 1. 1. 1.

$1 \quad 1$

600.600 .400 .280 .260

$260.280 .300 .300 .325 \cdot 350.300 .210 .218 .222 .224$.

(BLANK LINE) 
Listing of input for the Farmington aquifer model

Line No.

1051: $\quad 230.250 .250 .200 .200 .200 .200 .205 .280 .340 .400$.

1052: (BLANK LINE)

1053:

1054:

1055:

1056:

1057:

1058:

1059:

1060:

1061:

1062:

1063:

1064:

1065:

1066:

1067:

1068:

1069:

1070:

1071:

1072:

1073:

1074:

1075:

1076:

1077:

1078:

1079:

1080:

1081:

1082:

1083:

1084:

1085:

1086:

1087:

1088:

1089:

1090:

1091:

1092:

1093:

1094:

1095:

1096:

1097:

1098:

1099:

1100:

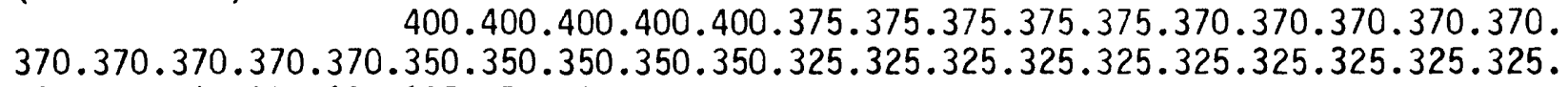
280.225 .210 .190 .190 .195 .270 .280 .300 .

(BLANK LINE)

$360.360 .360 .360 \cdot 360 \cdot 360 \cdot 360 \cdot 360 \cdot 360.360 \cdot 360 \cdot 360 \cdot 360 \cdot 360.360$. $360.360 \cdot 360 \cdot 360.360 \cdot 330 \cdot 330 \cdot 330 \cdot 330 \cdot 330 \cdot 323 \cdot 323.323 \cdot 323 \cdot 323 \cdot 320 \cdot 320 \cdot 320 \cdot 320 \cdot 320$. 300.280 .250 .188 .225 .250 .250 .240 .250 .

(BLANK LINE)

$300 \cdot 300 \cdot 300 \cdot 300 \cdot 300 \cdot 350 \cdot 350 \cdot 350 \cdot 350 \cdot 350 \cdot 330 \cdot 330 \cdot 330 \cdot 330 \cdot 330$. $330.330 .330 .330 .330 .325 .325 .325 .325 .325 \cdot 330 \cdot 330 \cdot 330 \cdot 330 \cdot 330 \cdot 325 \cdot 325 \cdot 325 \cdot 325 \cdot 325$. 320.250 .210 .187 .250 .250 .250 .235 .240 .

$260.260 .275 \cdot 315 \cdot 315 \cdot 310.280 .290 .300$

$340 \cdot 340.340 \cdot 340 \cdot 340 \cdot 355.355 .355 .355 .355 .330 \cdot 330.330 \cdot 330.330$. $330 \cdot 330 \cdot 330 \cdot 330 \cdot 330 \cdot 330 \cdot 330 \cdot 330 \cdot 330 \cdot 330 \cdot 340 \cdot 340 \cdot 340 \cdot 340 \cdot 340 \cdot 330 \cdot 330 \cdot 330 \cdot 330 \cdot 330$. 300.225 .186 .186 .250 .250 .275 .300 .300 . 225.245 .250 .264 .260 .260 .260 .275 .300 .

335.335 .335 .335 .335 .325 .325 .325 .325 .325 .330 .330 .330 .330 .330 . $325.325 .325 \cdot 325.325 .330 .330 \cdot 330 \cdot 330.330 \cdot 330 \cdot 330 \cdot 330 \cdot 330 \cdot 330 \cdot 330 \cdot 330 \cdot 330 \cdot 330 \cdot 330$. 250.183 .185 .245 .250 .250 .250 .250 . 200.225 .230 .235 .240 .240 .250 .250 .250 .270 $330.330 \cdot 330 \cdot 330 \cdot 330 \cdot 300 \cdot 300 \cdot 300 \cdot 300 \cdot 300$. $270.270 .270 .270 \cdot 270.260 .260 .260 .260 .260 .315 .315 .315 .315 .315 .250 .250 \cdot 250 \cdot 250.250$. $200.182 .200 .250 \cdot 250.250 .310 .300$. 200.190 .210 .225 .225 .230 .235 .235 .250 .250 .260 .275 275.275 .275 .275 .275 . $260.260 .260 .260 .260 .250 .250 .520 .250 .250 .220 .220 .220 .220 .220 .179 .179 \cdot 179 \cdot 179 \cdot 179$. 180.180 .250 .275 .

$200.180 .180 .200 \cdot 200 \cdot 200 \cdot 200 \cdot 200 \cdot 220 \cdot 230.240 .250 \cdot 250 \cdot 250 \cdot 250 \cdot 250.250$. $250.250 .250 .250 .250 .300 .300 .300 .300 .300 .275 .275 .275 .275 .275 .250 .250 .250 \cdot 250.250$. 250.250 .250 .250 .250 .225 .225 .225 .225 .225 .178 .178 .178 .178 .178 .179 .179 .179 .179 .179 . 235.250 .280 .300 .

$180.180 .185 .210 \cdot 190.200 .220 .230 .230 .225 .240 .240 .240 \cdot 240 \cdot 240.240 .240$. 240.240 .240 .240 .240 .250 .250 .250 .250 .250 .250 .250 .250 .250 .250 .250 .250 .250 .250 .250 . 250.250 .250 .250 .250 .225 .225 .225 .225 .225 .178 .178 .178 .178 .178 .220 .220 .220 .220 .220 . 230.250 .275 .300 .

180.175 .185 .190 .200 .216 .200 .195 .200 .155 .165 .200 .200 .200 .200 .200 .200 . 200.200 .200 .200 .200 .200 .200 .200 .200 .200 .200 .200 .200 .200 .200 .200 .200 .200 .200 .200 . 200.200 .200 .200 .200 .175 .175 .175 .175 .175 .178 .178 .178 .178 .178 .185 .185 .185 .185 .185 . 210.240 .250 .280 .280 .280 .280 .

170.168 .175 .190 .200 .200 .168 .161 .162 .161 .162 .165 .165 .165 .165 .165 .165 . 165.165 .165 .165 .165 .170 .170 .170 .170 .170 .175 .175 .175 .175 .175 .175 .175 .175 .175 .175 . 175.175 .175 .175 .175 .175 .175 .175 .175 .175 .180 .180 .180 .180 .180 .190 .190 .190 .190 .190 . 200.230 .250 .245 .245 .250 .260 .

180.167 .185 .185 .200 .195 .163 .161 .161 .161 .162 .165 .160 .160 .160 .160 .160$. 160.160 .160 .160 .160 .160 .160 .160 .160 .160 .175 .175 .175 .175 .175 .170 .170 .170 .170 .170 . 173.173 .173 .173 .173 .180 .180 .180 .180 .180 .176 .176 .176 .176 .176 .180 .180 .180 .180 .180 . 195.230 .250 .240 .250 .255 .255 .

180.167 .185 .185 .200 .195 .163 .161 .161 .161 .162 .165 .160 .160 .160 .160 .160 . 
Listing of input for the Farmington aquifer model

\section{Line No.}

1101:

1102:

1103:

1104:

1105:

1106:

1107:

1108:

1109:

1110:

1111:

1112:

1113:

1114:

1115:

1116:

1117:

1118:

1119:

1120:

1121:

1122:

1123:

1124:

1125:

1126:

1127:

1128:

1129:

1130:

1131:

1132:

1133:

1134:

1135:

1136:

1137:

1138:

1139:

1140:

1141:

1142:

1143:

1144:

1145:

1146:

1147:

1148:

1149:

1150:
$160.160 .160 .160 .160 .160 .160 \cdot 160 \cdot 160 \cdot 160.175 \cdot 175.175 .175 .175 .170 \cdot 170 \cdot 170 \cdot 170.170$. 173.173 .173 .173 .173 .180 .180 .180 .180 .180 .176 .176 .176 .176 .176 .180 .180 .180 .180 .180 . 195.230 .250 .240 .250 .255 .255 .

$180.167 .185 .185 .200 .195 \cdot 163.161 .161 .161 .162 .165 \cdot 160.160 .160 .160 .160$. 160.160 .160 .160 .160 .160 .160 .160 .160 .160 .175 .175 .175 .175 .175 .170 .170 .170 .170 .170 . 173.173 .173 .173 .173 .180 .180 .180 .180 .180 .176 .176 .176 .176 .176 .180 .180 .180 .180 .180 . 195.230 .250 .240 .250 .255 .255 .

$180.167 .185 .185 .200 .195 \cdot 163.161 .161 .161 .162 .165 .160 .160 .160 .160 .160$. 160.160 .160 .160 .160 .160 .160 .160 .160 .160 .175 .175 .175 .175 .175 .170 .170 .170 .170 .170 . 173.173 .173 .173 .173 .180 .180 .180 .180 .180 .176 .176 .176 .176 .176 .180 .180 .180 .180 .180 . 195.230 .250 .240 .250 .255 .255 .

$180.167 .185 .185 .200 .195 \cdot 163.161 .161 .161 .162 .165 .160 .160 .160 .160 .160$. 160.160 .160 .160 .160 .160 .160 .160 .160 .160 .175 .175 .175 .175 .175 .170 .170 .170 .170 .170 . 173.173 .173 .173 .173 .180 .180 .180 .180 .180 .176 .176 .176 .176 .176 .180 .180 .180 .180 .180 . 195.230 .250 .240 .250 .255 .255 .

185.167 .166 .165 .164 .163 .162 .161 .161 .161 .163 .159 .160 .160 .160 .160 .160 . $162.162 .162 .162 .162 .160 .160 .160 .160 .160 .165 .165 \cdot 165 \cdot 165.165 .170 \cdot 170.170 \cdot 170.170$. 175.175 .175 .175 .175 .177 .177 .177 .177 .177 .180 .180 .180 .180 .180 .185 .185 .185 .185 .185 . 195.230 .250 .230 .250 .250 .250 .

185.167 .166 .165 .164 .163 .162 .161 .161 .161 .163 .159 .160 .160 .160 .160 .160$. $162.162 .162 .162 .162 .160 .160 .160 .160 .160 .165 .165 \cdot 165 \cdot 165 \cdot 165 \cdot 170 \cdot 170 \cdot 170 \cdot 170.170$. 175.175 .175 .175 .175 .177 .177 .177 .177 .177 .180 .180 .180 .180 .180 .185 .185 .185 .185 .185 . 195.230 .250 .230 .250 .250 .250 .

185.167 .166 .165 .164 .163 .162 .161 .161 .161 .163 .159 .160 .160 .160 .160 .160 . 162.162 .162 .162 .162 .160 .160 .160 .160 .160 .165 .165 .165 .165 .165 .170 .170 .170 .170 .170 . 175.175 .175 .175 .175 .177 .177 .177 .177 .177 .180 .180 .180 .180 .180 .185 .185 .185 .185 .185 . 195.230 .250 .230 .250 .250 .250 .

185.167 .166 .165 .164 .163 .162 .161 .161 .161 .163 .159 .160 .160 .160 .160 .160 . $162.162 .162 .162 .162 .160 .160 .160 .160 .160 .165 .165 .165 .165 \cdot 165 \cdot 170.170 \cdot 170 \cdot 170.170$. 175.175 .175 .175 .175 .177 .177 .177 .177 .177 .180 .180 .180 .180 .180 .185 .185 .185 .185 .185 . 195.230 .250 .230 .250 .250 .250 .

$185.167 .166 .165 .164 .163 \cdot 162.161 .161 .161 .163 .159 .160 .160 .160 .160 .160$. 162.162 .162 .162 .162 .160 .160 .160 .160 .160 .165 .165 .165 .165 .165 .170 .170 .170 .170 .170 . 175.175 .175 .175 .175 .177 .177 .177 .177 .177 .180 .180 .180 .180 .180 .185 .185 .185 .185 .185 . 195.230 .250 .230 .250 .250 .250 .

$200.185 .185 .185 .180 .180 \cdot 170.165 .160 .160 .163 .159 .161 .161 .161 .161 .161$. 164.164 .164 .164 .164 .165 .165 .165 .165 .165 .172 .172 .172 .172 .172 .172 .172 .172 .172 .172 . 174.174 .174 .174 .174 .176 .176 .176 .176 .176 .175 .175 .175 .175 .175 .190 .190 .190 .190 .190 . 190.200 .210 .220 .250 .255 .260 .

$200.185 .185 .185 .180 .180 \cdot 170 \cdot 165.160 .160 .163 .159 .161 .161 .161 .161 .161$. 164.164 .164 .164 .164 .165 .165 .165 .165 .165 .172 .172 .172 .172 .172 .172 .172 .172 .172 .172 . 174.174 .174 .174 .174 .176 .176 .176 .176 .176 .175 .175 .175 .175 .175 .190 .190 .190 .190 .190 . 190.200 .210 .220 .250 .255 .260 .

$200.185 .185 .185 .180 .180 \cdot 170.165 .160 .160 .163 .159 .161 .161 .161 .161 .161$. 164.164 .164 .164 .164 .165 .165 .165 .165 .165 .172 .172 .172 .172 .172 .172 .172 .172 .172 .172 . 174.174 .174 .174 .174 .176 .176 .176 .176 .176 .175 .175 .175 .175 .175 .190 .190 .190 .190 .190 . 190.200 .210 .220 .250 .255 .260 .

200.185 .185 .185 .180 .180 .170 .165 .160 .160 .163 .159 .161 .161 .161 .161 .161$. 164.164 .164 .164 .164 .165 .165 .165 .165 .165 .172 .172 .172 .172 .172 .172 .172 .172 .172 .172 . 174.174 .174 .174 .174 .176 .176 .176 .176 .176 .175 .175 .175 .175 .175 .190 .190 .190 .190 .190 . 
Listing of input for the Farmington aquifer model

\section{Line No.}

1151:

1152:

1153:

1154:

1155:

1156:

1157:

1158:

1159:

1160:

1161:

1162:

1163:

1164:

1165:

1166:

1167:

1168:

1169:

1170:

1171:

1172:

1173:

1174:

1175:

1176:

1177:

1178:

1179:

1180:

1181:

1182:

1183:

1184:

1185:

1186:

1187:

1188:

1189:

1190:

1191:

1192:

1193:

1194:

1195:

1196:

1197:

1198:

1199:

1200:

190.200 .210 .220 .250 .255 .260 . 200.185 .185 .185 .180 .180 .170 .165 .160 .160 .163 .159 .161 .161 .161 .161 .161$. 164.164.164.164.164.165.165.165.165.165.172.172.172.172.172.172.172.172.172.172. 174.174 .174 .174 .174 .176 .176 .176 .176 .176 .175 .175 .175 .175 .175 .190 .190 .190 .190 .190$. 190.200 .210 .220 .250 .255 .260 . 250.225 .235 .215 .225 .188 .175 .200 .170 .160 .161 .159 .162 .162 .162 .162 .162$. 165.165 .165 .165 .165 .168 .168 .168 .168 .168 .169 .169 .169 .169 .169 .171 .171 .171 .171 .171 . 173.173 .173 .173 .173 .175 .175 .175 .175 .175 .175 .175 .175 .175 .175 .210 .210 .210 .210 .210 . 210.220 .240 .250 .235 .250 .260 .

$400.400 .475 .450 .450 .450 .400 .280 .175 .160 .159 .159 .158 .158 \cdot 158 \cdot 158.158$. $159.159 .159 .159 .159 .165 .165 .165 .165 .165 .169 .169 .169 .169 .169 .170 .170 \cdot 170.170 .170$. 170.170 .170 .170 .170 .175 .175 .175 .175 .175 .180 .180 .180 .180 .180 .210 .210 .210 .210 .210 . 215.250 .240 .250 .250 .250 .250 .

375.260 .200 .200 .190 .158 .158 .158 .158 .158 . 158.158 .158 .158 .158 .160 .160 .160 .160 .160 .165 .165 .165 .165 .165 .165 .165 .165 .165 .165 . 165.165 .165 .165 .165 .170 .170 .170 .170 .170 .175 .175 .175 .175 .175 .180 .180 .180 .180 .180 . 185.225 .250 .250 .250 .250 .250 .

400.300 .240 .250 .245 .200 .200 .200 .200 .200 158.158 .158 .158 .158 .158 .158 .158 .158 .158 .163 .163 .163 .163 .163 .160 .160 .160 .160 .160 . 160.160 .160 .160 .160 .165 .165 .165 .165 .165 .175 .175 .175 .175 .175 .170 .170 .170 .170 .170 . 180.190 .235 .240 .200 .175 .175 .

382.350 .300 .300 .245 .200 .200 .200 .200 .200 175.175 .175 .175 .175 .158 .158 .158 .158 .158 .157 .157 .157 .157 .157 .157 .157 .157 .157 .157$. 157.157 .157 .157 .157 .160 .160 .160 .160 .160 .160 .160 .160 .160 .160 .160 .160 .160 .160 .160 . 165.165 .175 .175 .170 .170 .170 .

400.250 .200 .200 .200 .200 .200 . 200.200 .200 .200 .200 .185 .185 .185 .185 .185 .165 .165 .165 .165 .165 .165 .165 .165 .165 .165 . 157.157 .157 .157 .157 .157 .157 .157 .157 .157 .156 .156 .156 .156 .156 .156 .156 .156 .156 .156$. 156.156 .155 .170 .155 .155 .155 .

330.240 .240 .240 .240 .240 . 250.250 .250 .250 .250 .200 .200 .200 .200 .200 .200 .200 .200 .200 .200 .195 .195 .195 .195 .195 . $200.200 .200 .200 .200 .187 .187 .187 .187 .187 .187 .187 .187 .187 .187 .180 .180 \cdot 180.180 .180$. 180.175 .155 .155 .155 .180 .180 .

275.275 .275 .275 .275 $275.275 .275 .275 .275 .260 .260 .260 .260 .260 .250 .250 .250 \cdot 250 \cdot 250 \cdot 240.240 \cdot 240 \cdot 240.240$. 255.255 .255 .255 .255 .240 .240 .240 .240 .240 .250 .250 .250 .250 .250 .250 .250 .250 .250 .250 . 230.240 .240 .245 .250 .250 .250 .

$300.300 .300 \cdot 300 \cdot 300$ $350 \cdot 350 \cdot 350 \cdot 350 \cdot 350 \cdot 350 \cdot 350 \cdot 350 \cdot 350 \cdot 350 \cdot 350 \cdot 350 \cdot 350 \cdot 350 \cdot 350 \cdot 325 \cdot 325 \cdot 325 \cdot 325 \cdot 325$. $270.270 .270 .270 .270 .270 .270 .270 .270 .270 .300 .300 .300 .300 .300 \cdot 350.350 \cdot 350 \cdot 350.350$. 350.325 .325 .325 .325 .340 .350 .

$350 \cdot 350 \cdot 350 \cdot 350 \cdot 350$ 400.400 .400 .400 .400 .450 .450 .450 .450 .450 .475 .475 .475 .475 .475 .400 .400 .400 .400 .400 . $375.375 .375 .375 .375 .350 .350 .350 .350 .350 .360 \cdot 360 \cdot 360 \cdot 360 \cdot 360 \cdot 400.400 .400 \cdot 400.400$. (BLANK LINE)

(BLANK LINE)

(BLANK LINE)

(BLANK LINE)

(BLANK LINE)

7.90E-08 
Listing of input for the Farmington aquifer mode 1

\begin{tabular}{|c|c|c|c|c|c|c|c|c|}
\hline 1201: & 1 & 1 & & & & & & \\
\hline 1202: & 1000 & 1000 & 1000 & 1000 & 1000 & 1000 & 1000 & 1000 \\
\hline 1203: & 1000 & 1000 & 1000 & 1000 & 1000 & 1000 & 1000 & 200 \\
\hline 1204: & 200 & 200 & 200 & 200 & 200 & 200 & 200 & 200 \\
\hline 1205: & 200 & 200 & 200 & 200 & 200 & 200 & 200 & 200 \\
\hline 1206: & 200 & 200 & 200 & 200 & 200 & 200 & 200 & 200 \\
\hline 1207: & 200 & 200 & 200 & 200 & 200 & 200 & 200 & 200 \\
\hline 1208: & 200 & 200 & 200 & 200 & 200 & 200 & 200 & 200 \\
\hline 1209: & 200 & 200 & 200 & 200 & 1000 & 1000 & 1000 & 1000 \\
\hline 1210: & 1000 & 1000 & 1000 & 1000 & 1000 & 1000 & 1000 & 1000 \\
\hline 1211: & 1 & 1 & & & & & & \\
\hline 1212: & 1000 & 1000 & 1000 & 1000 & 1000 & 1000 & 1000 & 1000 \\
\hline 1213: & 1000 & 1000 & 1000 & 1000 & 1000 & 1000 & 1000 & 1000 \\
\hline 1214: & 200 & 200 & 200 & 200 & 200 & 200 & 200 & 200 \\
\hline 1215: & 200 & 200 & 200 & 200 & 200 & 200 & 200 & 1000 \\
\hline 1216: & 1000 & 1000 & 1000 & 1000 & 1000 & 1000 & 1000 & 1000 \\
\hline 1217: & 1000 & 1000 & & & & & & \\
\hline 1218: & 1 & 0 & 249 & 1 & 1 & 1 & 24 & 1.00 \\
\hline 1219: & 21 & 45 & -0.00 & 1.5 & 0.1 & 25. & & \\
\hline 1220: & 24 & 40 & -0.00 & 1.5 & 0.1 & 15. & & \\
\hline 1221: & 25 & 44 & -0.00 & 1.5 & 0.1 & 25. & & \\
\hline 1222: & 2 & 67 & .90 & & & & & \\
\hline 1223: & 2 & 68 & .70 & & & & & \\
\hline 1224: & 2 & 69 & .267 & & & & & \\
\hline 1225: & 2 & 70 & .267 & & & & & \\
\hline 1226: & 2 & 71 & .10 & & & & & \\
\hline 1227: & 3 & 66 & .70 & & & & & \\
\hline 1228: & 3 & 67 & .35 & & & & & \\
\hline 1229: & 3 & 71 & .089 & & & & & \\
\hline 1230: & 4 & 51 & .002 & & & & & \\
\hline 1231: & 4 & 52 & .002 & & & & & \\
\hline 1232: & 4 & 53 & .002 & & & & & \\
\hline 1233: & 4 & 54 & .002 & & & & & \\
\hline 1234: & 4 & 55 & .002 & & & & & \\
\hline 1235: & 4 & 56 & .0008 & & & & & \\
\hline 1236: & 4 & 57 & .0008 & & & & & \\
\hline 1237: & 4 & 58 & .0008 & & & & & \\
\hline 1238: & 4 & 59 & .0008 & & & & & \\
\hline 1239: & 4 & 60 & .009 & & & & & \\
\hline 1240: & 4 & 61 & $8.83 E-03$ & & & & & \\
\hline 1241: & 4 & 62 & $8.83 E-03$ & & & & & \\
\hline 1242: & 4 & 63 & .10 & & & & & \\
\hline 1243: & 4 & 64 & .089 & & & & & \\
\hline 1244: & 4 & 65 & .267 & & & & & \\
\hline 1245: & 4 & 66 & .55 & & & & & \\
\hline 1246: & 4 & 71 & $2.21 E-01$ & & & & & \\
\hline 1247: & 5 & 51 & .02 & & & & & \\
\hline 1248: & 5 & 69 & $2.21 E-01$ & & & & & \\
\hline 1249: & 5 & 70 & $2.21 E-01$ & & & & & \\
\hline 1250: & 5 & 71 & .10 & & & & & \\
\hline
\end{tabular}




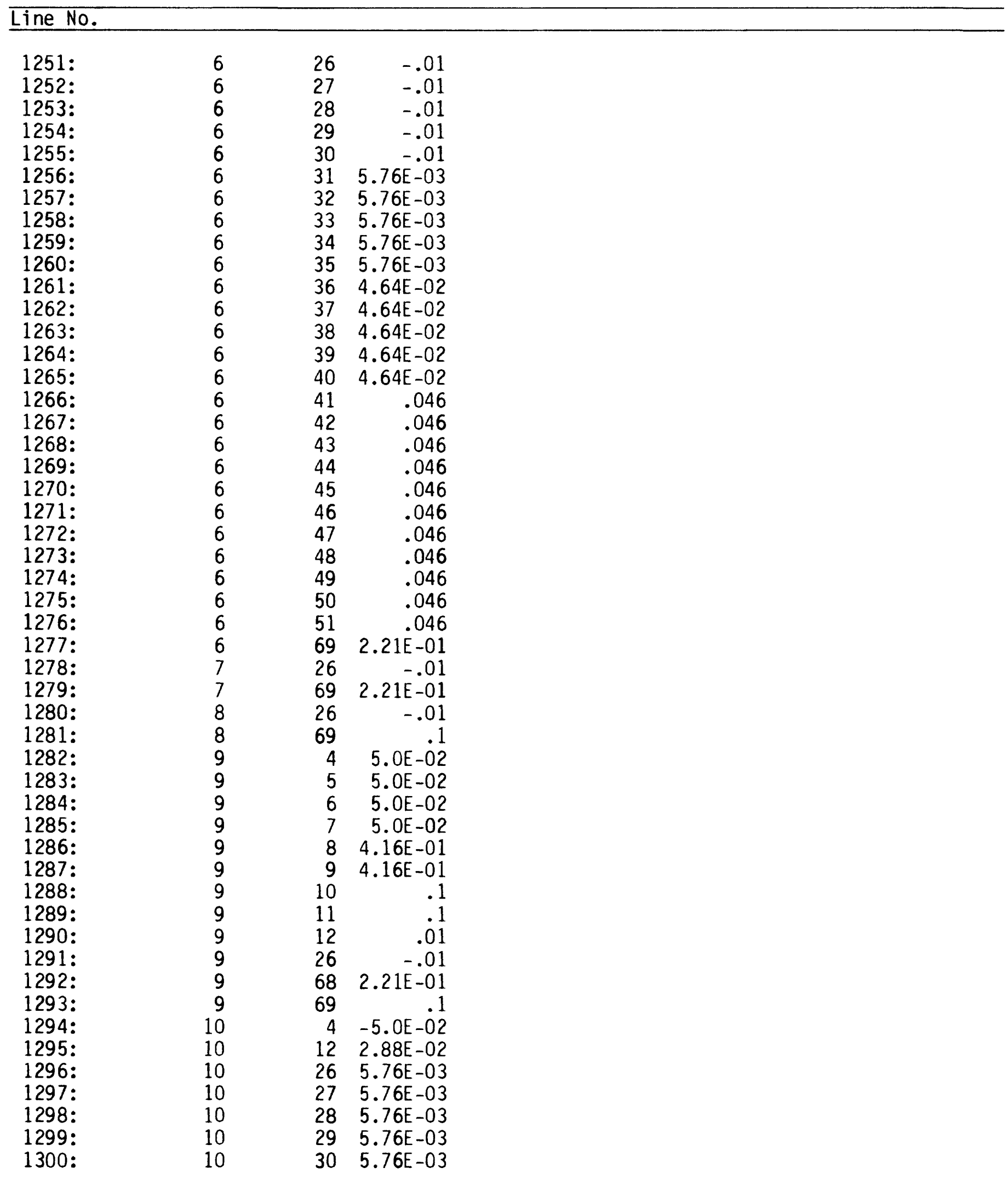


Listing of input for the Farmington aquifer mode 1

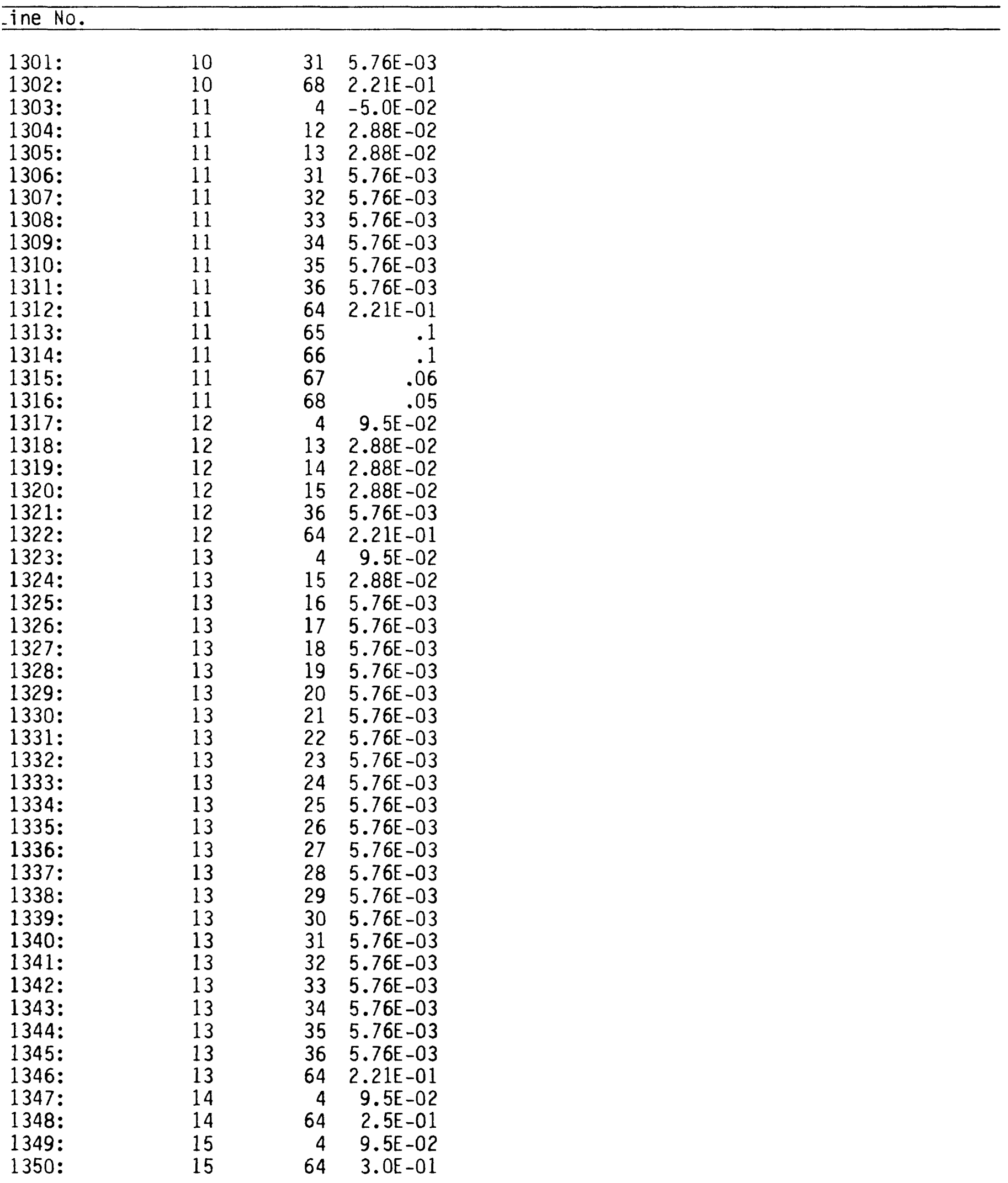


Listing of input for the Farmington aquifer model

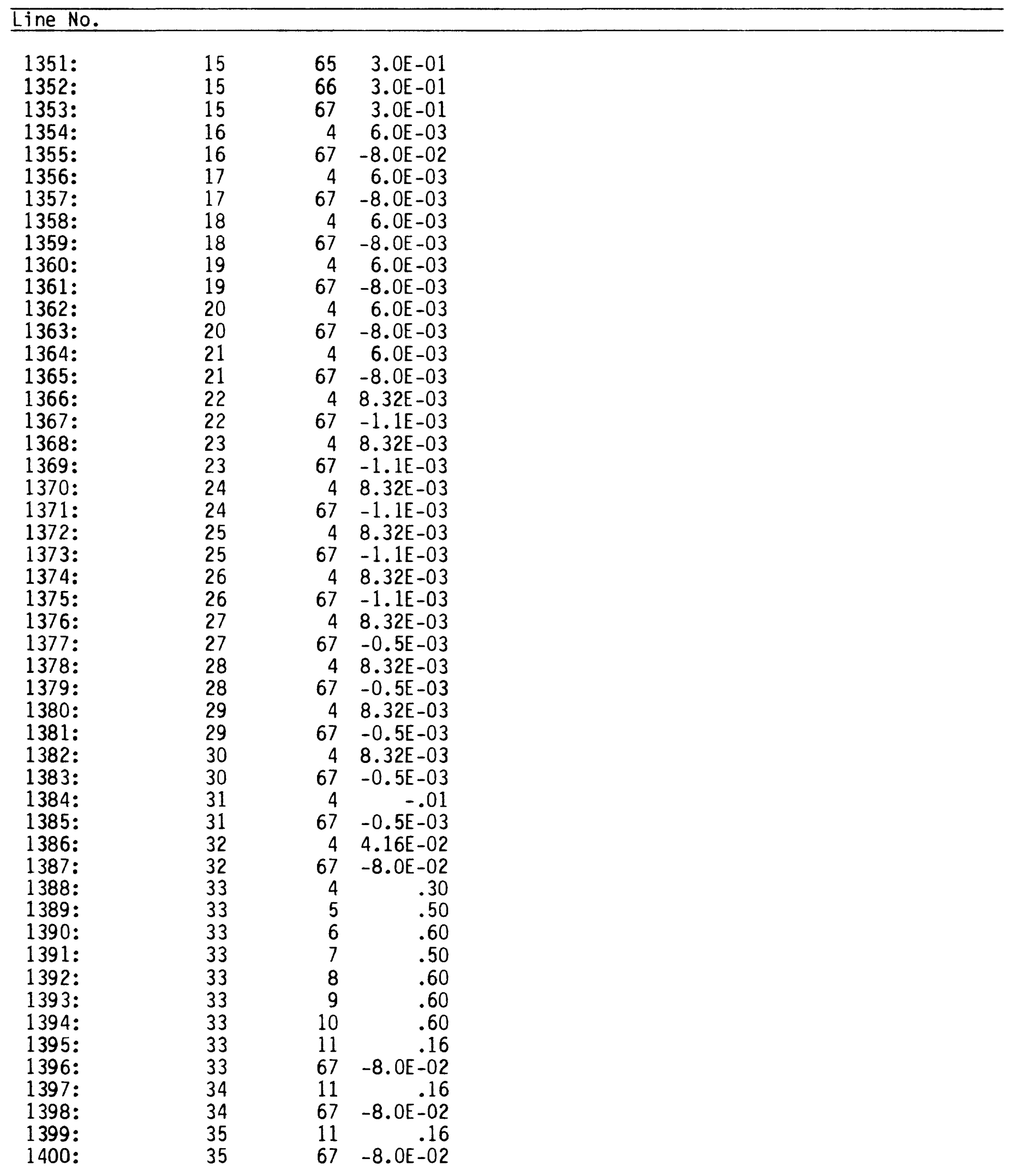


Listing of input for the Farmington aquifer model

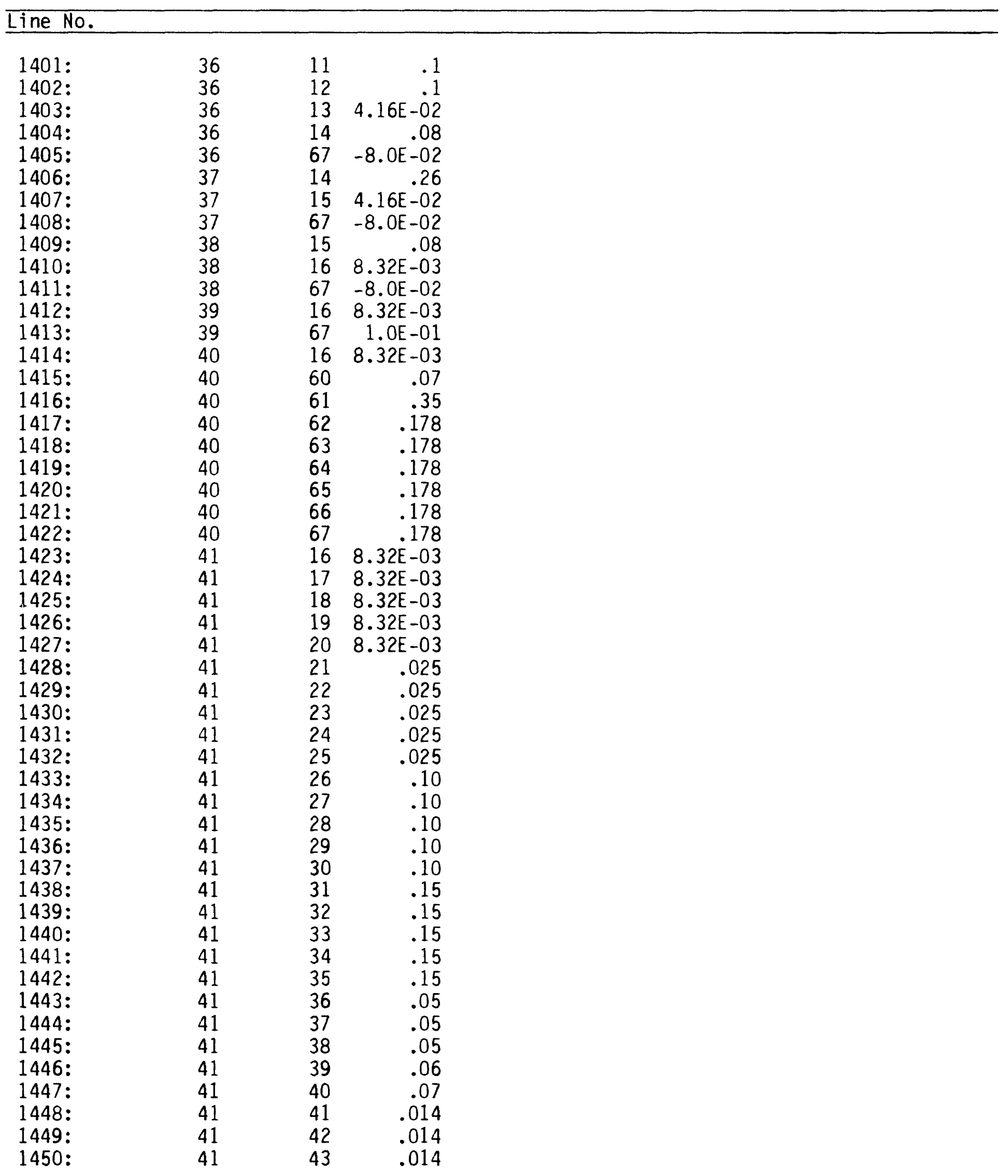


Listing of input for the Farmington aquifer mode 1

\begin{tabular}{llll}
\hline Line No. & & & \\
\hline $1451:$ & 41 & 44 & .014 \\
$1452:$ & 41 & 45 & .014 \\
$1453:$ & 41 & 46 & .01 \\
$1454:$ & 41 & 47 & .01 \\
$1455:$ & 41 & 48 & .01 \\
$1456:$ & 41 & 49 & .01 \\
$1457:$ & 41 & 50 & .01 \\
$1458:$ & 41 & 51 & .01 \\
$1459:$ & 41 & 52 & .01 \\
$1460:$ & 41 & 53 & .01 \\
$1461:$ & 41 & 54 & .01 \\
$1462:$ & 41 & 55 & .01 \\
$1463:$ & 41 & 56 & .0044 \\
$1464:$ & 41 & 57 & .0044 \\
$1465:$ & 41 & 58 & .0044 \\
$1466:$ & 41 & 59 & .0044
\end{tabular}

